\title{
PALAEOXYLOTOMICAL STUDIES IN THE CENOZOIC PETRIFIED FORESTS OF GREECE. PART TWO - CONIFERS
}

\author{
Stănilă Iamandei ${ }^{1 *}$, Eugenia Iamandei ${ }^{1}$, Dimitrios Velitzelos $^{2} \&$ Evangelos Velitzelos $^{2}$
}

Received: 21 May 2021 / Accepted: 12 November 2021/ Published online: 4 December 2021

\begin{abstract}
This paper reports the palaeoxylotomical study of petrified conifer remains from Velitzelos collection, originating from some fossiliferous sites of Greece, especially from the Aegean area (Evros, Limnos, Lesbos), aged of late Oligocene to early Miocene. Ten species were identified: Cupressinoxylon akdikii, Juniperoxylon acarcae, Tetraclinoxylon velitzelosii, Taxodioxylon gypsaceum, Taxodioxylon taxodii, Glyptostroboxylon rudolphii, Glyptostroboxylon tenerum, Pinuxylon pineoides, Pinuxylon halepensoides and Pinuxylon sp. aff. Pinus canariensis. These new identifications add new elements to the forest assemblages of the Oligocene - Miocene Greek flora, useful for understanding the evolution of the Cenozoic palaeovegetation and palaeoclimate in the Aegean area.
\end{abstract}

Keywords: Aegean area, Petrified Forest, Cupressaceae, Pinaceae.

\section{INTRODUCTION}

The evolution of the Cenozoic flora in the "Aegean area" is generally known from various palaeobotanical and palynological studies previously published. This paper represents a palaeoxylotomical study on a part of "Velitzelos Collection" which is housed in the great Collection the Faculty of Geology and Geoenvironment of the National and Kapodistrian University of Athens, a public collection available for any further studies or revisions. The first part of this study (Velitzelos et al., 2019) presented, in detail, the geology of the fossiliferous sites from where samples of fossil wood were collected, as well as their conditions of fossilization, usually by silicification. Moreover, it briefly presented the results of the previous palaeobotanical and palaeoxylotomical identifications, sending for more details to Velitzelos et al. (2014).

The present paper, which represents the second part of our study, included the xylotomical study of 200 samples of fossil wood with coniferous structure, collected by Professor Evangelos Velitzelos, from the Aegean area during his numerous geological field trips and, in order to contribute to outlining of the taxonomic composition of the Cenozoic Petrified Forests of Greece, we have identified some coniferous species, of Cupressinoxylon, Juniperoxylon, Tetraclinoxylon, Taxodioxylon, Glyptostroboxylon and Pinuxylon. In the following part of this study, the identification of some dicotyledonous woods coming from the same "Aegean area" will be performed. Thus, the results of our palaeoxylotomical studies could contribute to a better understanding of the evolution of the arboreal vegetation in Greece, during OligoceneMiocene time and of the Cenozoic palaeoclimate, in the Aegean area.

\section{GEOLOGICAL FRAMEWORK}

The material here studied was collected from the Aegean area, both from continental and insular part, from some Oligocene-Miocene fossiliferous sites, from Evros, Limnos and Lesbos.

Evros - is a part of the Eastern part of the region of East Macedonia and Thrace (Fig. 1), representing the continental part of the Aegean area. The geological evolution of Evros region, as summed up by Voudouris et al. (2007), shows that the sedimentation started here in Eocene and continued in Oligocene and early Miocene, when the main phase of Cenozoic magmatism happened (Innocenti et al., 1984; Del Moro et al., 1988). According to Kopp (1965), Petrescu et al. (1980) and Velitzelos et al. (2002), occurencies of plant fossil remains are related mainly to the Rupelian-Chattian lignite-bearing volcanosedimentary levels of the Provatonas series, which discordantly cover the volcanic rocks from around Fylakto village. Also, some fine-grained volcano-sedimentary layers which preserve many silicified woods appear around Lefkimi locality (Voudouris et al., 2007).

From Evros, by palaeobotanical studies of plant remains collected from the late Oligocene volcano-sedimentary levels of Provatonas series, the presence of many coniferous taxa was revealed, as: Quasisequoia couttsiae (Heer) Kunzmann, Taxodium dubium (Sternberg) Heer, Calocedrus suleticensis (Brabenec) Kvaček, Pinus palaeostrobus Ettingshausen (needle leaves in fascicles of five), Pinus cf. rigios Ettingshausen, cf. Cunninghamia miocenica Ettingshausen, beside numerous angiospermous taxa (Velitzelos et al., 2014). Petrified wood frequently appears in the Evros region, especially close to the localities Lagina, Lira, Lykofi, Fylakto, Provatonas, Tycheron, Trifili, Lefkymi, Sapes and Aëtohori, sites visited also by us. But few previous identifications of

\footnotetext{
1* Geological Institute of Romania (GIR), iamandei@gmail.com

${ }^{2}$ National \& Kapodistrian University of Athens (NKUA), Faculty of Geology and Geoenvironment, velJim@geol.uoa.gr

* Corresponding author
} 


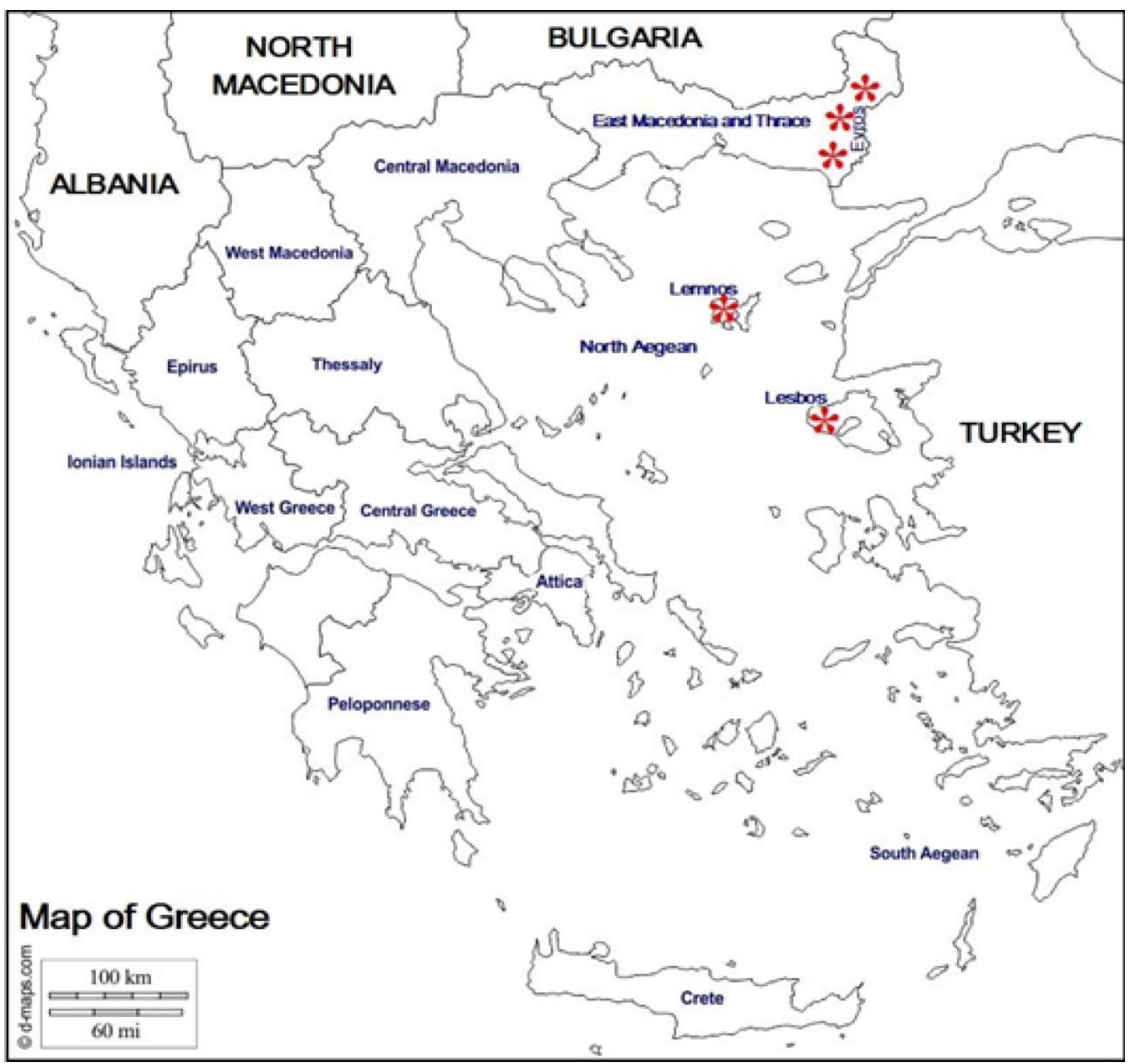

Fig. 1 Map of Greece; * marks the areas where the studied fossil wood samples were collected (according with d-maps.com, with modifications).

fossil wood from these sites have been done (Petrescu et al., 1980; Petrescu \& Velitzelos, 1981; Selmeier \& Velitzelos, 2000). In the first part of this study on the material from "Velitzelos Collection", some palm stems were identified (Velitzelos et al., 2019).

Limnos Island (Fig. 1) - presents a mid Eocene-lower Miocene molassic sedimentary basement, overlain by volcanic products (subdivided into three units: Katalako, Romanou and Myrina) of Lower Miocene age and then, by an Upper Quaternary sedimentary formation (Davis 1960, Innocenti et al. 1984, Roussos 1993). There, silicified or opalized plant fossils appear especially around Moudros Gulf, in the early Miocene pyroclastics of Romanou Unit, considered of Burdigalian age (Innocenti et al., 1994; Voudouris et al., 2007). More geological details were included in the first part of the study, Velitzelos et al. (2019).
From Limnos Island, few fossil plant remains were previously identified and we cite here the only two conifers described: Glyptostrobus europaeus (Brongniart) Unger and Sequoia abietina (Brongniart) Erw. Knobloch (Velitzelos et al. 2014). But numerous fossil wood remains were collected in the previous years, sometimes from excavations, from around the villages of Fergani, Romanou, Moudros, Varos, Rossopouli, Portianou, Thanos and Kontias, and on the hill of Paradisi, and these samples are kept in the Collection of the Faculty of Geology and Geoenvironment (NKUA). There are some lignotaxa previously described from there, such as Laurinoxylon ehrendorferi Berger, Cornoxylon pappi Berger (Berger, 1953), and a problematic conifer, initially described as Pinoxylon parenchymatosum Süss et Velitzelos, later revised as species of Lesbosoxylon (Süss \& Velitzelos (2010). More recently, some palm fossil taxa were described (Velitzelos et al., 2019). 
Lesbos Island (Fig. 1) - hosts the Geopark "Petrified Forest of Lesvos", where numerous petrified tree trunks and other fossil vegetal remains frequently appear in relationship with the intense volcanic activity developed during the early Miocene, age 18-19 Ma, i.e. Aquitanian and Burdigalian (Koufos et al., 2003). Details of the entire geological evolution of Lesbos Island are thoroughly exposed in the papers of Pe-Piper (1980a, b); Katsikatsos et al. (1982, 1986), Pe-Piper \& Piper (1993); Koufos et al. (2003); Zouros et al. (2007); Vasileiadou \& Zouros (2012) and were sinthesized in Velitzelos et al. (2014, 2019).

Lesbos Island yields numerous vegetal fossils, not only inside the Geopark "Petrified Forest of Lesvos", which hosts numerous monumental in situ petrified tree trunks appear but also, in many fossiliferous sites around Bali Alonia, Eressos, Antissa, Sigri, Hidira, Gavathas, Molyvos, Polichnitos, Mesotopos, Plomari, Akrasi or on Megalonisi Islet, where large accumulations of silicified wood as tree trunks or fragmentary can be found. Syntheses of the scientific information on the palaeobotanic research in the European protected geopark "Petrified Forest of Lesvos" are presented in the first part of this study Velitzelos et al. (2019) and in Mantzouka et al. (2009, 2013, 2017, 2019a, b), comprising also all the previous identifications of fossil plants by the study of fossil macroremains (Table 1), partly presented also in the synthesis of Velitzelos et al. (2014). Identified conifers include: Sequoia abietina (Brongniart) Erw. Knobloch [vel Taxodium sp.], Cunninghamia miocenica Ettingshausen, Tetraclinis salicornioides (Unger) Kvaček and Pinus sp. (cone). Also, some palm remains were identified (Velitzelos et al., 2019).

\section{MATERIAL AND METHODS}

We had for the present study 200 samples from the collection of the Professor Evangelos Velitzelos, gathered during the last decades from the late Oligocene - early Miocene volcano-sedimentary deposits of the Aegean Area, as presented above. Oriented thin-sections of petrographic type were prepared from each sample, according to the three standard directions - transversal, tangential and radial. The studied material and the oriented thinsections are all registered and kept as "Velitzelos Collection" inside the Collection of the Faculty of Geology and Geoenvironment of the National and Kapodistrian University of Athens (NKUA). These sections have been palaeoxylotomically studied under transmitted light microscope and all the anatomical details were described for each specimen, using the scientific terms as defined by the "IAWA list of microscopic features for softwood identification", from the Compendium edited by IAWA Comittee in 2004 (Richter et al., 2004). The photos of the xylotomical details were captured with on an "EverFocus" video-camera adapted to the microscope, using the software "AVerMedia", and the images were processed with specialized computer programs. The identification of the unknown original tree was subsequently performed by comparison with previously described similar aspects of fossil or current wood structures, from published scientific papers (all included in the References chapter). The systematics follows APG (2009, 2016), Christenhusz et al. (2011) and the ICN-Shenzhen Code (Turland et al., 2018).

\section{SYSTEMATICS}

Gymnosperms

Division Pinophyta Cronquist, Takht. \& Zimm.e ex Reveal, 1996

Order Cupressales Link, 1829

Family Cupressaceae Bartlett, 1830 (sensu lato - Gadek et al., 2000)

Genus Cupressinoxylon Göppert emend. Dolezych, 2005 Cupressinoxylon akdikii Özgüven-Ertan, 1977

Fig. 2, a-i.

\section{Material}

The studied material comes from Greece, Aegean area both from insular and continental part. It is represented by 24 samples of petrified (silicified) wood with cupressaceous structure, collected from Evros, from late Oligocene volcano-sedimentary deposits: from Lefkimi, the samples numbered with the field numbers Lfk.78, 82, 156, 217, 219, 259, 260, 272, 281; from Sappes, the samples Spp.6, 1081, 1091, 1102, 1108; and from Aetohory the sample Aet.1134. Also, some samples were collected from early Miocene volcano-sedimentary deposits, from Lesbos Island - the samples numbered with field numbers Lsv.2, 360, 361, 406, 408; and from Limnos - the samples numbered with Li.195, 196, 198, 237. All these samples are registered as "Velitzelos Collection" and stored inside the Collection of the Faculty of Geology and Geoenvironment of the National and Kapodistrian University of Athens (NKUA).

\section{Microscopic description}

Growth rings - appear variably sized in cross section, often wide, of over 50 cells, with abrupt transition (sometimes almost gradual) from the early wood to the late wood, which is represented by 3-5 rows of smaller and radially flattened cells, marking the growth rings boundaries which become quite distinct, since the early wood always starts with larger cells. Normal resin canals - absent.

Tracheids - have a polygonal shape with rounded corners in cross-section, sometimes deformed by compression. 
Table 1. List of Cenozoic conifers identified by paleoxylotomical studies, from Greece (according with Mantzouka et al., 2013 and Velitzelos et al., 2014, with modifications).

\begin{tabular}{|c|c|c|}
\hline No. & Species described from Lesbos & Current equivalent \\
\hline 1 & Ginkgoxylon lesboense Süss et Velitzelos, 2003 & \multirow{2}{*}{ Ginkgoales, Ginkgo wood type } \\
\hline 2 & Ginkgoxylon diversicellulatum Süss et Velitzelos, 2003 & \\
\hline 3 & Podocarpoxylon articulatum Süss et Velitzelos, 2000 & \multirow{2}{*}{ Podocarpaceae wood type (?) } \\
\hline 4 & Podocarpoxylon graciliradiatum Süss et Velitzelos, 2000 & \\
\hline 5 & Chimairoidoxylon lesboense Süss et Velitzelos, 1999 & \multirow{2}{*}{ Conifer indet. } \\
\hline 6 & Chimairoidoxylon conspicuum Süss et Velitzelos, 2001 & \\
\hline 7 & Lesbosoxylon paradoxum Süss et Velitzelos, 2010 & \multirow{5}{*}{ Conifer wood of Piceoxylon-type or Pinuxylon-type(?) } \\
\hline 8 & Lesbosoxylon pseudoparadoxum Süss et Velitzelos, 2010 & \\
\hline 9 & Lesbosoxylon diversiradiatum Süss et Velitzelos, 2010 & \\
\hline 10 & Lesbosoxylon graciliradiatum Süss et Velitzelos, 2010 & \\
\hline 11 & Lesbosoxylon ventricosuradiatum Süss et Velitzelos, 2010 & \\
\hline 12 & Tetraclinoxylon velitzelosii Süss, 1997 & Tetraclinis wood type \\
\hline 13 & Thujoxylon antissum Süss et Velitzelos, 1998 & Thuja root-wood type \\
\hline 14 & Taxaceoxylon biseriatum Süss et Velitzelos, 1994 & Conifer of Taxus type? \\
\hline 15 & Taxodioxylon gypsaceum (Göppert) Kräusel, 1949 & \multirow{4}{*}{ Sequoia wood-type, } \\
\hline 16 & Taxodioxylon albertense (Penhallow) Shimakura, 1940 & \\
\hline 17 & Taxodioxylon pseudoalbertense Nishida \& Nishida, 1985 & \\
\hline 18 & Taxodioxylon megalonissum Süss et Velitzelos, 1997 & \\
\hline 19 & Taxodioxylon lesbium (Unger) Mantzouka et Sakala, 2017 & Taxodium wood type? \\
\hline 20 & Glyptostroboxylon microtracheidale Süss et Velitzelos, 1997 & Cunninghamia lanceolata (Lambert) Hooker \\
\hline
\end{tabular}

In the early wood, their radial / tangential diameter is of 15-35(50) / 15-30(40) $\mu \mathrm{m}$, and the wall thickness is of 4-7 $\mu \mathrm{m}$ the double wall. In the transitional wood their diameters are quite similar, slightly diminishing in size toward the final 3-5 rows of late wood smaller tracheids, of $8-15 / 10-15 \mu \mathrm{m}$ in diameter and slightly thicker walled, of 8-11 $\mu \mathrm{m}$ the double wall. In cross section, the cells appear regularly arranged in 2-9 radial rows between two successive rays, and intercellular spaces between are often present. Their density is 1600-1716 tracheids per $\mathrm{mm}^{2}$. On the radial walls, the pits appear in uniseriate arrangement or sometimes biseriate, spaced, opposite, and are slightly molded by the tangential walls. The pits are round, of bordered type, with 17-22 $\mu \mathrm{m}$ in diameter, with large chamber and round to elliptic aperture. On the tangential walls the pitting is usually absent or rarely appear as smaller pits of $12-15 \mu \mathrm{m}$, uniseriately arranged. Helical thickenings absent but striations, in longitudinal view, sometimes are present. Crassulae are sometimes present. Callitroid thickenings are not present. Organic deposits are usually absent.

Axial parenchyma - is present in cross section and appear few, in diffuse arrangement, scattered throughout the entire growth ring, as smaller cells, usually with some dark content. In vertical sections the string of parenchyma cells shows transverse end walls thin and smooth, and sometimes resin content as rare, small or big, dark globules or granules.

Rays - appear thin and linear, in cross section. In tangential view they appear as exclusively uniseriate, sometimes with some biseriate storeys, are low to medium tall, with $1-10(-15)$ cells, to taller of 16 to 27 cells, or more. Ray density is 5-9 rays per tangential $\mathrm{mm}$. Regarding the ray composition, the rays are homogeneous, composed by parenchymatous ray cells, the marginals slightly taller. Ray tracheids are not present. The end-walls of ray parenchyma cells are smooth. The horizontal walls of ray parenchyma cells are smooth and pitted. Indentures absent. Cross fields with small cupressoid pits of 7-10(-12) $\mu \mathrm{m}$ in diameter, as 1-2(-3) pits in one row arranged in normal cross fields, to 4-6 in the taller cross fields, when in 2 superposed rows arranged, and with inclined slit-like apertures. Sometimes globules of resin or granules are present inside the ray cells.

Resin canals - are absent.

Mineral inclusions - are not present.

\section{Affinities and discussions}

During the paleoxylotomical study, we observed that 26 samples of petrified wood coming from Aegean area show coniferous structure with distinct growth rings, no resin canals, few parenchyma, uniseriate or biseriate pits on the radial walls of the tracheids, the pits often located in a kind of nest formed by crassulae and the tracheidal wall which molds the pits, tangential pits smaller and cross field pitting of cupressoid type, anatomical features suggesting a great affinity to cupressaceous wood-type (Vaudois \& Privé, 1971; Watson \& Dallwitz, 2008; Ibrahim, 2015; InsideWood, 2004). A very similar structure appears at the extant Cupressus L., as described by Greguss (1955) and Schweingruber (1990), an important member of the Subfamily Cupressoideae Rich. ex Sweet, 1826 - as appear in the last classification of family $\mathrm{Cu}-$ pressaceae - sensu lato (Gadek et al., 2000; Farjon, 2005a; Christenhusz et al., 2011).

For this type of fossil wood, Goeppert (1850) created the fossil genus Cupressinoxylon Goeppert, describing more specimens, but not specifying a very clear diagnosis. 

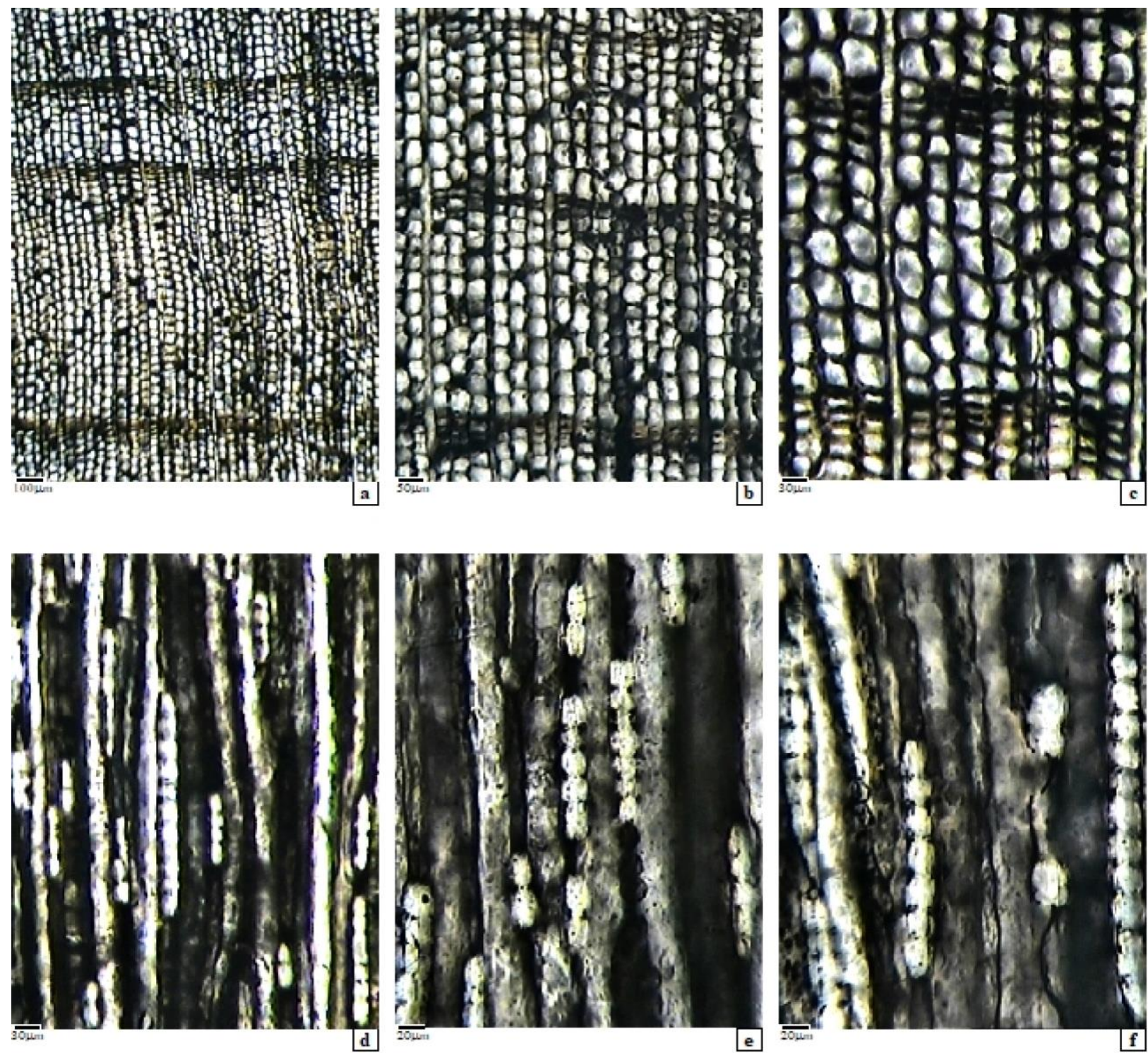
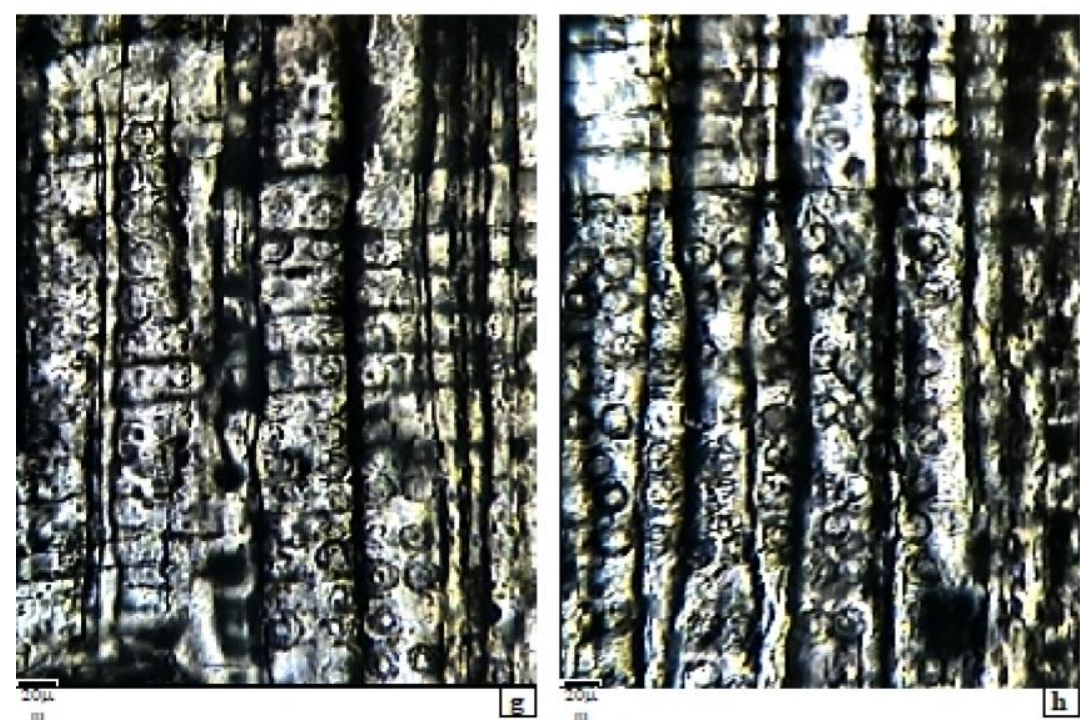

Fig. 2 a-i, (graphic scale). Cupressinoxylon akdikii Özgüven-Ertan, 1977 (Specimen Lfk.156).

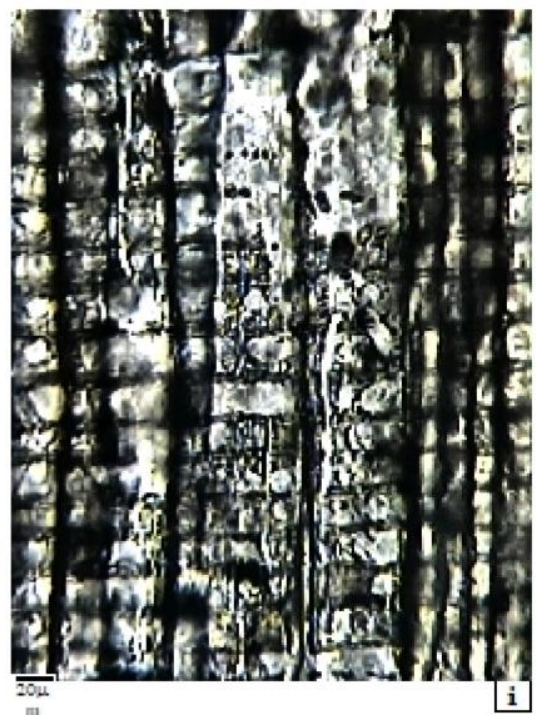

a-c: Cross section - abrupt transition, distinct growth rings; parenchyma few, diffuse; rays uniseriate; d-f: Tangential section pitting on tracheids absent or rare, as uniseriate small pits (arrow); rays uniseriate; $\mathbf{g - i}$ : Radial section - tracheidal pitting 1(-2)seriate, opposite; rays homogeneous, badly preserved cross fields with 1-2(-3) cupressoid pits (arrow). 
Vaudois \& Privé (1971) cited a diagnosis reformulated after many previous authors. Bamford et al. (2002) made a proposal to conserve the name Cupressinoxylon against Retinodendron, even if it was previously considered a "wastebasket" taxon (Müller-Stoll \& Schultze-Motel, 1990; Wang et al., 1996). The 'diagnosis' attributed to Goeppert was emended by Dolezych (2005). Interesting observations on it were also made by Bodnar et al. (2015) and Ruiz \& Bodnar (2019).

We compared the description of the studied specimens with some other cupressaceous fossil forms previously described, as for example Chamaecyparixylon (Iamandei \& Iamandei, 2000a, 2017; Iamandei et al., 2013), or even Cupressinoxylon sp. of Thuja type (Iamandei et al., 2008a, c; 2011; 2012), which show some general xylotomical resemblances. In fact, the presence of fossil Thuja is debatable for the Aegean area, and maybe for Europe, since the current genus has, and maybe had, a disjunctive distribution in the Northern Hemisphere, in Eastern Asia and Northern America. However, some fossil forms equivalent to this genus were described from Cretaceous rocks of northern Europe and up to Pliocene it appears to have had a migration to more southern regions; after Pliocene it would have disappeared from Europe (Farjon, 2005). In the Aegean area no fossil wood remain of this this genus was described till now (Velitzelos D. et al., 2014), except a form of fossil wood from Lesbos Island described as Thujoxylon antissum by Süss et Velitzelos (2008), and interpreted as root-wood.

- A comparison of the here studied specimens with other previously described "cupressaceous" fossil structures shows many similarities with the forms of $\mathrm{Cu}$ pressinoxylon described by Kräusel $(1919,1949)$ and by Zalewska (1953), as generic xylotomical features.

- The species Cupressinoxylon saxonicum of Schönfeld (1957) has large pits on radial tracheidal walls and nodular tangential walls of ray parenchyma, so it is slightly diferent from our specimens.

- The form of Cupressinoxylon described Van der Burgh (1964) is similar to C. gothani Kräusel, having numeous radial tracheidal pits with visible crassulae, pitted axial parenchyma with thick and smooth horizontal walls, and typical cupressoid cross-section. These details slightly different at here studied specimens.

- Greguss (1967) described some very poorly preserved specimens as forms of Cupressinoxylon sp. (Sakala et al., 2018), so we exclude them from comparison.

- Özgüven-Ertan (1977) described a new species, Cupressinoxylon akdikii, studiing a fossil wood collected from a Turkish Miocene site, close to Aegean area, having a xylotomy very similar to the extant mediterranean cypress, Cupressus sempervirens L., and our studied specimens are very similar to this species.

- Dupéron-Laudouéneix (1979) described a Cenozoic wood of Cupresinoxylon from Charente, France, which resemble our specimens, having similar cupressoid cross-fields.

- Dolezych-Mikolai (2005) and Dolezych \& Schneider (2006a), described some European Cenozoic forms of Cupressinoxylon, identifed as C. cupressoides Kräusel, C. kostyniukii Dolezych \& Schneider, C. xanthocyparioides Dolezych \& Schneider, compared with some possible extant equivalents from the world as Taiwania Hayata, Calocedrus Kurz and, respectively, Xantocyparis Farjon \& T.H. Nguyên. Their xylotomy is different from the here studied specimens.

- Kłusek (2014) described a Cupressinoxylon canadense (Schroeter) Kräusel which has ray-tracheids and a C. polonicum (Kostyniuk) Kräusel which has abundant parenchyma, so both are different from our specimens.

- Asensi Amorós (2016), studying some actual or sub-fossil woods (archaeological wood-remains from Egypt), and described them as having the typical xylotomy of the Mediterranean Cypress (i.e. Cupressus sempervirens L.), resembling much that of our specimens.

- The petrified wood recently studied from Turkey, by Güngör et al. (2019) resulted in the description of 12 fossil taxa and between them a Cupressinoxylon wood, which has "gradual transition from earlywood to latewood and growth-ring boundary distinct, uniseriate tracheidal pitting on radial and on tangential walls, abundant axial parenchyma with slightly nodular end-walls, low rays with cupressoid cross field pits", similar to the current Cupressus sempervirens, which is living now across the Mediterranean region, in coastal areas. And also, is very similar to our studied specimens.

- Also, Akkemik (2019) described from Pliocene deposits of central-northern Turkey a Cupresssinoxylon pliocaenica Akkemik, as perfectly similar to Cupressus sempervirens L., having "roughly the same wood features" with the current species, as is described by Greguss (1955) or Schweingruber (1990), and is very similar to our specimens' description.

The studied specimens, even if sometimes poorly preserved, present xylotomical characters very similar to the forms described by Özgüven-Ertan (1977), by Güngör et al. (2019) and by Akkemik (2019), and to the single current Mediterranean species, Cupressus sempervirens L., as is also described by Asensi Amorós (2016). Based upon these, we assign our studied specimens to the Miocene species Cupressinoxylon akdikii Özgüven-Ertan, 1977 as having very similar cupressoid pits in cross fields, similar radial pitting on tracheids, and similar axial parenchyma. It represents a fossil equivalent of the current species, Cupressus sempervirens L., known as the Mediterranean cypress, present in Mediterranean countries and in Middle East (Farjon, 2005; Akkemik \& Yaman, 2012). 
Genus Juniperoxylon Kräusel, 1949, emend. van der Burgh, 1973

Juniperoxylon acarcae Akkemik, 2020

Fig. 3, a-i.

\section{Material}

The studied samples of fossil wood were collected from Greece, the Aegean area, both from continental and insular part. All of them showed a similar cupressaceous xylostructure, of Juniperus-type and were grouped under the genus Juniperoxylon. There are 13 fragments of petrified (silicified) wood and were collected from late Oligocene deposits from Evros, i.e. from Lefkimi - the samples numbered with field numbers Lfk.2, 4a, 5a, 52, 60, 72, 176, 261, 266, 282, 306 and from Sappes - the sample Spp.1077; and also, from the early Miocene of Limnos island - the sample Li.203. The studied samples are registered as "Velitzelos Collection" and stored in the Collection of the Faculty of Geology and Geoenvironment, of the NKUA.

\section{Microscopic description}

Growth rings - usually narrow, but sometimes larger, and with distinct ring-boundaries which appear often wavy in cross-section. The transition from early wood to late wood is sometimes gradual, but often abrupt. Axial resin canals not present.

Tracheids - in the early wood have polygonal rounded in cross section, (15-)26-40 / 15-22 $\mu \mathrm{m}$ the radial / tangential diameter and relatively thick walls, of 4-7 $\mu \mathrm{m}$ double wall. In the late-wood they are smaller, with diameters of 5-12 / 9-20 $\mu \mathrm{m}$ and thick walls 8-10 $\mu \mathrm{m}$ (double wall). Intercellular spaces present. Tracheid length could not be measured. On their radial walls round bordered pits are present, sometimes ornate, of $15-17 \mu \mathrm{m}$ in diameter, uniseriate, sometimes biseriate. On the tangential walls smaller round pits of 6-7 $\mu \mathrm{m}$ diameter appear, showing round to slightly oval and obliquely oriented apertures. Helical thickenings and callitroid thickenings absent, but, sometimes, warty areas appear. Organic deposits, as resin remains, sometimes are present inside tracheids.

Axial parenchyma - is often abundant, dispersed or in short tangential rows, especially in transitional and late wood. The parenchyma transverse end walls are nodular. Rays - exclusively uniseriate and in tangential view usually appear of low to medium height, having 1-9(-15) cells tall, sometimes more. Ray density is 6-12 rays per tangential $\mathrm{mm}$. Regarding their composition, the rays are homogeneous, with cells all procumbent and raytracheids absent. The horizontal walls of ray cells are thick, smooth and pitted, and the tangential end-walls are inclined, distinctly pitted and with typical juniperoid nodules, beadlike. The cross-field pits are of cupressoid type, usually as 1-2(4) small pits, of 6-8 $\mu \mathrm{m}$, with oblique slit-like apertures and in vertical or horizontal arranged. Indentures not observed or absent. The ray cells often keep resinous remains inside.

Resin canals - are absent.

Mineral inclusions - are absent.

\section{Affinities and discussions}

The cupressaceous xylotomy of the studied 13 specimens marked by the presence of 'juniperoid nodules', i.e. the nodular end walls of ray-cells, suggest a wood-type of Juniperus L., a genus which belong to Cupressoideae subfamily (Gadek et al., 2000; Farjon, 2001, 2005; Christenhusz et al., 2011). Here you are the essential xylotomic characters of the genus Juniperus: tracheids with exclusively uniseriate radial small pits; axial parenchyma abundant, with transverse end-walls pitted and nodular; low rays, with cupressoid cross-fields and juniperoid nodules (Greguss, 1955; Watson \& Dallwitz, 2008, onwards). The xylotomy of Juniperus-type appear to be very similar to that of Cupressus-type, but ray-height and ray-frequency are different (rays smaller in height, but more numerous in Juniperus) and mainly the end walls of ray-cells, which are typically nodular in Juniperus (as 'juniperoid nodules'), smooth or rarely weakly nodular in Cupressus, details which can help in distinguishing between these two genera (Greguss, 1955; Schweingruber, 1990; Akkemik \& Yaman, 2012; Crivellaro \& Schweingruber, 2013; Román-Jordán, 2016; RománJordán et al., 2017).

- The genus Juniperoxylon was created firstly by Houlbert (1910), but it was Kräusel who have imposed it by publishing the species Juniperoxylon silesiacum (Prill) Kräusel (in Prill \& Kräusel, 1919). Also, Kräusel (1949) validated the genus name and wrote a short protologue for it: "Wood, similar to Cupressinoxylon. Ray cell walls, at least the terminal ones, more or less strongly pitted, so determining the 'juniperoid nodules' on the end-wall of ray cells, ('Juniperustüpfelung', Gothan, 1905), and traumatic wood never with resin pockets". The typespecies stated was Juniperoxylon turonense Houlbert, described from the Miocene of Touraine, France (Kłusek, 2014; Dolezych, 2016). However, this species was reconsidered by Philippe \& Bamford (2009) and revised as not correctly identified, having a structure of Taxodioxylontype, devoid of 'Juniperustüpfelung'. But, since the original material of the type-species is lost and this genus name should be typified, the authors concluded that its use should not be recommended.

- Vaudois \& Privé (1971), had revised all the $\mathrm{Cu}$ pressaceous fossil lignotaxa published to date, and have imagined an identification key for 'cupressaceous' wood structures, specifying that Juniperus wood-type has "specific juniperoid nodules on the inclined tangential walls of ray-cells, in radial view". 

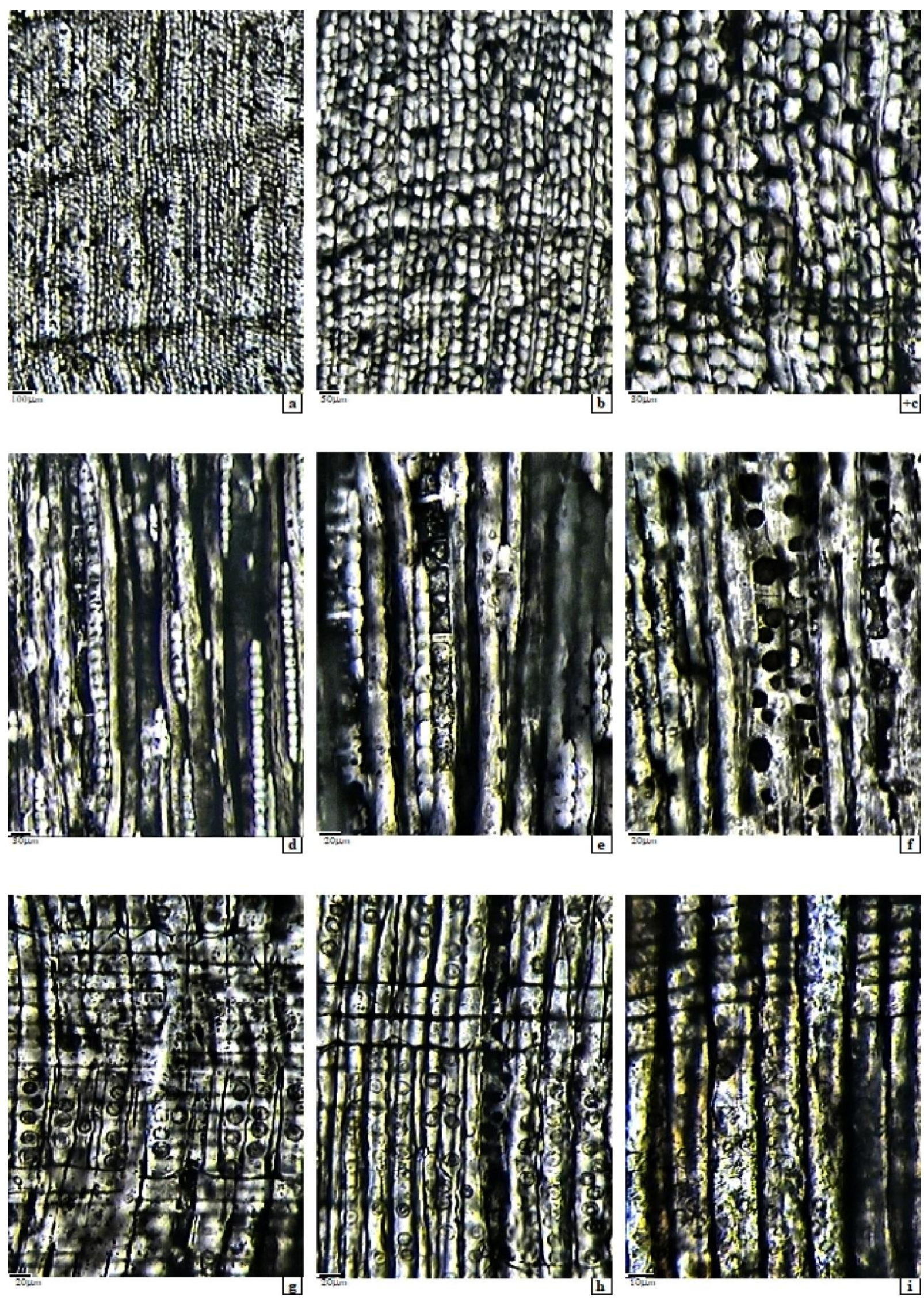

Fig. 3 a-i. (graphic scale). Juniperoxylon acarcae Akkemik, 2020. (Specimen Lfk.266).

a-c: Cross section - transition abrupt, distinct growth rings; parenchyma few, diffuse; rays uniseriate; d-f: Tangential section pitting on tracheids absent; nodular parenchyma end walls (arrow); rays uniseriate; g-i: Radial section - tracheidal pitting uniseriate; rays homocellular, cells all procumbent, marginals taller; tangential end-walls with juniperoid nodules (inclined arrow); poorly preserved cross fields with 1-2 cupressoid pits, usually arranged as vertical pairs pits (horizontal arrow). 
- But a well documented discussion on the validity of the Juniperoxylon genus was made by Dolezych (2016), who also described a new species, Juniperoxylon schneiderianum, and discussed the validity of some European previously described species, probably ignoring the recommendation of Philippe \& Bamford (2009). This species has diffuse axial parenchyma and cross-fields with cupressoid pits but also taxodioid and no indentures, so it is slightly different from our studied specimens.

- Recently, Ruiz \& Bodnar (2019), revising the type material of Cupressinoxylon zamunerae described by Bodnar et al. (2015), have transferred it to Juniperoxylon, as a new combination: J. zamunerae (Bodnar et al.) Ruiz et Bodnar, taking into account the presence of juniperoid nodules on the end walls or ray-cells, the aspect of the cross-fields with vertical pairs, the scarce and diffuse axial parenchyma, and the rays tall of up to 34 cells and radial pits on the tracheids, spaced or contiguous, features partially present in our specimens as well.

- In the same paper, the authors discuss some previously described species of Juniperoxylon, reassigned in time to other taxa (Ruiz \& Bodnar, 2019) and made a revision of the described species of Juniperoxylon, resulting only 9 species that can be considered correctly identified. However, since Philippe \& Bamford (2009) have infirmed the identification of J. turonense Houlbert, there are only 8 valid species left, which we add to the species recently described by Akkemik (2020a).

- Similar fossil wood remains were described by Akkemik et al. (2016), and by Acarca-Bayam et al. (2018) from central Anatolia, as wood of Juniperus type and, more recently, a new species named Juniperoxylon acarcae was described by Akkemik (2020a), a form closes to the current Mediterranean forms, and which presents a xylotomical details very similar to those of the here studied specimens.

Thus, our studied specinmens present a typical xylotomy of Juniperus, as described by Greguss (1955), Vaudois \& Privé (1971), Dolezych (2016) and Ruiz \& Bodnar (2019). According to the two comparative tables of Ruiz \& Bodnar (2019), including the description and discussion accompanying the recent new species described by Akkemik (2020a), a species which has many similarities with our specimens regarding the tracheidal pitting, the axial parenchyma, the pits from cross-fields, we attribute the studied specimens to the species Juniperoxylon acarcae Akkemik, 2020.

The xylotomical details are also very similar to the extant species of the junipers characteristic to Eastern Mediterranean (Aegean) area, as Juniperus macrocarpa Sibth. et Sm., J. drupacea Labill., J. excelsa M.Bieb., J. communis L. or J. phoenicea L., as Asensi Amorós (2016) cite also from the current Egyptian indigenous flora, also present in Sinai.

According with Farjon (2001, 2005), Adams (2004, 2007) and Mao et al. (2010), Juniperus is a genus that has numerous species distributed almost all around the world, but especially in the Northern Hemisphere, as a result of the Oligocene - Miocene diversification and migration in Eurasia and North America, related to climate evolution. Some of Juniperus species appear distributed in Europe and Mediterranean Sea, including also the Canary Islands, Azores, Northern Africa and Asia Minor, and have migrated as far as the Arabian Peninsula and the "Afromontane zones" of Eastern Africa, like Juniperus procera Hochst. ex Endl. (Mao et al., 2010, Fig. 1,5,6).

Genus Tetraclinoxylon Grambast, 1951

Tetraclinoxylon velitzelosii Süss, 1997

Fig. 4, a-i.

\section{Material}

11 samples from the studied material showed a similar cupressaceous xylostructure of Tetraclinis-type, marked by the round lumina of the thick-walled tracheids and were grouped under the genus Tetraclinoxylon Grambast. The samples were collected from Greece, Aegean area, from late Oligocene volcano-sedimentary deposits from Evros region: from Lefkimi - the samples with the field numbers Lfk.151, 300, 311, 312; from Sappes - the samples Spp 25, 33, 35; from Trifili - the sample Tf.132. Also, some samples come from early Miocene deposits of Limnos - the samples Li.133, 211, and of Lesbos - the sample Lsv.13b. The studied material is registered as "Velitzelos Collection and stored in the Collection of the Faculty of Geology and Geoenvironment", of the NKUA.

\section{Microscopic description}

Growth rings - are variably wide in the cross section, having sometimes over 25-30 rows of thick-walled cells with rounded lumina, with quite abrupt size-transition, sometimes gradual, to the late-wood, which is represented by 3-5(-7) rows of smaller, very thick-walled cells and radially flattened, distinctly marking the growth ring boundary. Resin canals are absent (Fig. 4a-c).

Tracheids - have polygonal shape with rounded corners in cross section, in the early wood showing obviously The pits have ornate chamber and round to slightly elliptic aperture. In tangential view, sometimes, uniseriate smaller pits of 12-15 $\mu \mathrm{m}$ can appear, often with irregular arrangement, or even slightly alternate. Helical thickenings not present, but striations, in longitudinal view, often appear. Crassulae rarely present. Callitroid thickenings not present. Organic deposits absent.

Axial parenchyma - appear as few cells in diffuse arrangement in cross section, scattered throughout the entire growth-ring as smaller cells, relatively thin-walled and, usually, with some dark content, as plugs, globules or granules.

In vertical view, the string of parenchyma cells shows and smooth transverse end-walls of $2-3 \mu \mathrm{m}$, or feebly 

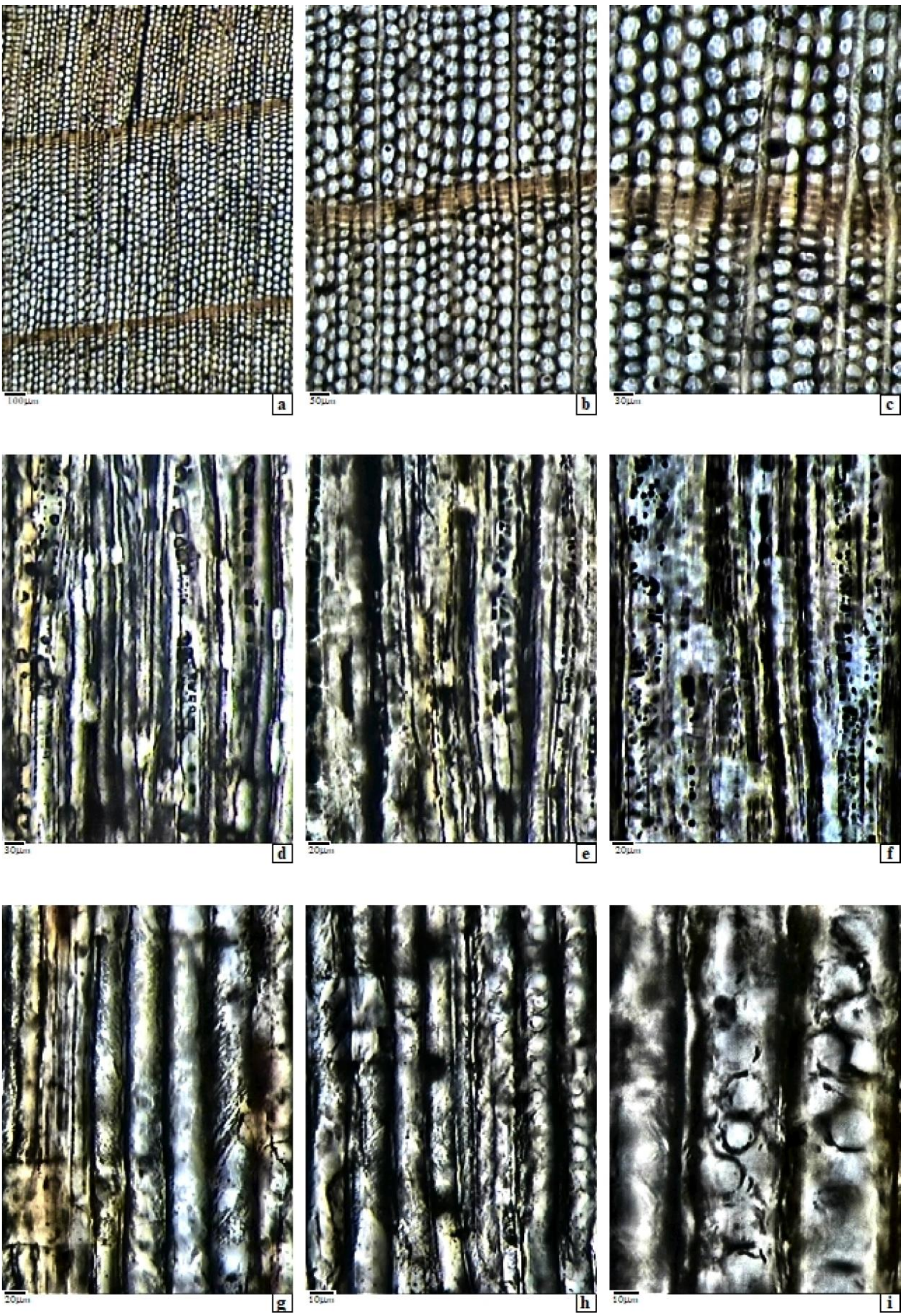

Fig. 4 a-i. (graphic scale). Tetraclinoxylon velitzelosii Süss, 1997. (Specimen Tf.132).

a-c: Cross section - quite abrupt transition, distinct growth rings; tracheids with typicaly round lumina (arrow); parenchyma few; d-f: Tangential section - pitting on tracheids absent; parenchyma with dark remains; low rays (arrow); g-i: Radial section - stiations on tracheids (arrow) and pitting 1(2)-seriate, opposite or irregular; poorly preserved cross fields (arrow). 
nodular, with 2-3 small nodules, often difficult to observe because of the resin content.

Rays - are exclusively uniseriate and, in tangential section, show cells with round to wide-oval shape, of 20-25 $\mu \mathrm{m}$ in diameter, usually as rays of low type, mostly of 3-5 cells tall, but sometimes of even more than 25 cells. Ray density is 9-12 rays per tangential $\mathrm{mm}$. In radial section the rays are of homogeneous type, with cells all procumbent and without ray-tracheids. The ray-cells have smooth horizontal walls, less pitted, of 2-5 $\mu \mathrm{m}$ thick, and the tangential walls not pitted, of $2.5 \mu \mathrm{m}$ thick. Indentures - are not visible or absent. In cross field, 1-2(-4) cupressoid pits appear, mostly in 1-2 horizontal rows, sometimes irregularly arranged. They appear as round cupressoid pits of 10-12 $\mu \mathrm{m}$ in diameter and with oblique slit-like apertures.

Resin canals - are not present.

Mineral inclusions - are not present.

\section{Affinities and discussions}

The xylotomical characters observed in 11 studied specimens of fossil wood, indicate a structure of 'cupressaceous' type, and the thick-walled tracheids with round lumen in cross-section (a detail of high taxonomic value), together with other microscopic details, like the specific radial pitting, the smooth or weakly nodular horizontal wall of the axial parenchyma and the cupressoid pits in cross field suggest a similarity to the current genus Tetraclinis Mast. (Gothan, 1905; Prill, 1913; Peirce, 1937; Phillips, 1948; Kräusel, 1949; Greguss, 1955). There is the single species of this genus, Tetraclinis articulata (Vahl) Mast., which appear as a small tree of 6-8 m tall, rarely reaching $15 \mathrm{~m}$, or only with shrub habit. It occurs now as a "living fossil" in the extreme South of Spain, in Morocco, North Algeria, North Tunisia, and in Malta, also perhaps North-Eastern Libya, as endangered species or vulnerable populations (Farjon, 2005; Earle, 2020).

Previously it was considered "the single member of Callitroideae group without callitroid thickenings" (Greguss, 1955) but, in the last classification of the family Cupressaceae lato sensu, the genus Tetraclinis Mast. is a member of Cupressoideae subfamily (Gadek et al., 2000; Farjon, 2005a; Christenhusz et al., 2011), side by side with Cupressus L., Juniperus L., Xanthocyparis Farjon et Hiep, Microbiota Komarov, Platycladus Spach, Calocedrus Kurz, Chamaecyparis Spach, Fokienia Henry et Thomas, Thuja L., and Thujopsis Endl.

- $\quad$ The fossil genus Tetraclinoxylon was created by Grambast (1951) having T. boureaui Grambast as typespecies, which was described from the Oligocene (Chattian) of Paris Basin, as a perfect correspondent of the current Tetraclinis Mast. (Grambast, 1962). The original diagnosis of Tetraclinoxylon Grambast, 1951 sounds like this: «Wood showing structure of Cupressinoxylon s.s. (sensu stricto) (Gothan, 1905). Cross section of the tracheids are rounded. Cross field pits with inclined slit-like apertures. Indentures absent and there are no thickenings of the tangential wall of the ray cells. No callitroid thickenings. Average height of ray cells - less than $25 \mu \mathrm{m}$ » (translated from French). Our studied specimens fit with this diagnosis.

- Such a fossil cupressoid wood which was described by Vallin (1966) from Portugal as Cupressinoxylon lusitanense Vallin, but having a very a similar xylotomy with the current Tetraclinis, was renamed by Süss (1997) Tetraclinoxylon lusitanense (Vallin) Süss as new combination, as having xylotomical details similar to the current Tetraclinis. Our specimens have quite similar details.

- $\quad$ Privé (1973) described T. vulcanense from the Pliocene of Puy-de-Dôme, France, with xylotomy, also very similar to the current Tetraclinis. Sakala (2003), identified a $T$. vulcanense by the study of a big petrified late Eocene trunk from Kučlín, Czech Rep., initially wrongly determined by Březinová et al. (1994) as Podocarpoxylon helmstedtianum Gottwald, 1966. Some similarities with our specimens were observed.

- A Mediterranean fossil species from Miocene deposits from northern Sardinia - Tetraclinoxylon anglonae Biondi - was described by Biondi (1979), having, also, many similarities to the current Tetraclinis, and also with our studied material.

- Desplats (1983), studying a Cretaceous (Albian) fossil wood collected from Pas-de-Calais area, described a new species as Tetraclinoxylon amedroi, having xylotomical details similar to the current Tetraclinis.

- Süss, 1997 has described Tetraclinoxylon velitzelosii, as a new Mediterranean fossil species, from the early Miocene of Lesbos, with xylotomy similar to the current Tetraclinis: tracheids pitting 1-2 seriate, axial parenchyma with nodular horizontal walls, relatively high rays with cupressoid cross-fields. Very similar details we observed in our studied specimens.

- The study of numerous specimens from the Carpathian area revealed another Cenzoic species was described as Tetraclinoxylon romanicum Iamandei et Iamandei, 2000, as presenting minor xylotomical differences considered as representing intraspecific variability (like the variable frequency of the crassulae); they were assigned to the same species (Iamandei \& Iamandei, 2000b; Iamandei et al., 2005b; 2008a,b; 2011). The here studied specimens present some similarities with this carpathian species.

Also, we cite here Sakala (2011, pers. comm.), who observed such variability on slides prepared from wood of living Tetraclinis articulata (Vahl) Mast. (No. 2280, UPMC, Paris): "very often 3-4 typically cupressoid pits per field appear, mostly in marginal ray cells; very rare biseriate portions of pitting on radial tracheid walls and crassulae are present especially on the wider tracheids of early wood, but no biseriate portion in rays were observed", thus completing the descriptions found in Kräu- 
sel (1949), Grambast (1951), Greguss (1955), Vaudois \& Privé (1971), Privé (1973).

Thus, we observed in our specimens that have gradual transition from the early wood to the late-wood, sometimes quite abrupt in cross section, and the polygonalrounded tracheids have thick to very thick walls, with round or rounded lumina. Also, uniseriate to biseriate and opposite radial pits, sometimes slightly irregular, often separated by crassulae. Axial parenchyma is present, few, in diffuse arrangement, with smooth and thin transverse end-walls, rarely feebly nodular. The rays are usually uniseriate, of low to medium type, mostly of 3-5 cells tall, but sometimes up to 25 cells or more, with lateral intercellular spaces and cross fields with 1-2(-4) cupressoid pits.

Since the description of the studied specimens perfectly agree with that of the species diagnosis of Süss (1997), a species created on fossil wood collected from the same area, the Lesbos Island, we decided to attribute them to the species Tetraclinoxylon velitzelosii Süss, 1997.

The current corespondent has presently a very restricted Mediterranean distribution, but we must imagine that this genus had a more extended Cenozoic area in Europe, around the Paratethys Sea, indicating, for that span of time, a subtropical to warm-temperate paleoclimate of Mediterranean type. Otherwise, by the study of the Oligocene-Miocene leaf imprints found throughout Europe, a Tetraclinis salicornioides (Unger) Kvaček was described, that perfectly corresponds to the present-day species (Stancu \& Ţicleanu, 1975; Kvaček et al., 1989; Givulescu, 1997; Kvaček \& Hably, 1998), as well as in North America (Kvaček et al., 2000). However, Kvaček (2002) quote the existence of a fossil subxerophytic form, identified as Tetraclinis brachyodon (Brongniart) Mai \& Walther, as humid subtropical element coming from MidEocene to Pliocene, in all Europe, probably from Caucasus up to Italy or to Germany - where it was first described. Kovar-Eder \& Kvaček (1995) cited it from Croatia, and Givulescu (1997) cited it from Transylvania. These two fossil species coexisted, and it is very possible that this subxerophytic form have had a special wood structure, still unknown up to this day. Further studies may add better arguments to such a hypothesis. The "whole plant" principle (Sakala, 2004) could be helpful.

Genus Taxodioxylon (Hartig) Gothan, 1905

Taxodioxylon gypsaceum (Göppert) Kräusel, 1949

Fig. 5, a-i.

\section{Material}

From the studied samples, 7 specimens with cupressaceous xylostructure of "taxodiaceous" type closer to that of current Sequoia, were grouped under the genus Taxodioxylon. These samples were collected from Aegean area, either from dispersed fragments of petrified wood, or from in situ big silicified trunks found in the continental part of Greece, in the late Oligocene deposits of Evros: 76 sample Aet.315 from Aetohory and sample Lfk.313 from Lefkimi. Also, some samples were collected from the insular part, from early Miocene deposits of Limnos Island: Li.134, 135, and of Lesbos Island, the samples Lsv.335, 336 and 337. The studied material is registered under the above specified numbers as "Velitzelos Collection" and stored in the Collection of the Faculty of Geology and Geoenvironment, of NKUA.

\section{Microscopic description}

Growth rings - are relatively wide in cross section, of 11$40(-65)$ cells or more, often with slightly gradual transition from earlywood to latewood, sometimes quite abrupt, giving a distinct aspect to the growth-rings boundaries, marked by some rows of smaller thick walled latewood tracheids, as final wood. Normal resin canals absent, but sometimes tissue or even canals with traumatic character appear.

Tracheids - with polygonal shape (with 4-5-6 sides) in cross section, often variably sized, having the radial / tangential diameter of 35-65(-80) / 25-45(-70) $\mu \mathrm{m}$ and relatively thin walls - of $3-5 \mu \mathrm{m}$ the double wall in the early-wood, usually gradually diminishing in size toward the late-wood, which is represented by $2-5(-13)$ rows of tracheids with smaller lumen, of 10-18 / 15-25 $\mu \mathrm{m}$ in diameters and thicker walls - of 6-10 $\mu \mathrm{m}$ double wall. The cells are regularly arranged in 1-9 radial rows between two successive rays, sometimes with intercellular spaces. Their density is $1500-1716$ tracheids per $\mathrm{mm}^{2}$. In longitudinal view, the tracheids show rounded or tapered endings, are of high type but their length is often difficult to measure. Tracheidal pitting on the radial walls are usually 1-3-seriate, oppositely arranged, as abietinean round bordered pits, with $18-22 \mu \mathrm{m}$ in diameter, with large chambers and round to slightly elliptic apertures. Sometimes certain irregularities appear, as storeys of opposite pairs of pits in the uniseriate row, or even as small portions biseriate. Crassulae are usually present. On the tangential tracheidal walls pitting is absent but, few uniseriate smaller pits, of 8-10(15) $\mu \mathrm{m}$ can seldom appear. Also, sometimes, on the endings of tracheids, warty areas appear. Helical or callitroid thickenings absent. Organic deposits absent.

Axial parenchyma - appears rather abundant in cross section, in short tangential lines or in diffuse arrangement, dispersed throughout the entire growth ring as smaller cells among the tracheids, or in the terminal wood as slightly irregular short tangential lines, usually with dark content. In the longitudinal sections, the parenchyma shows thin and smooth transverse end-walls or, sometimes, with 1(-2) weak nodules. Inside the parenchyma cells, globular or granular resin content appear.

Rays - appear numerous, linear and thin in cross section. In tangential section they appear exclusively uniseriate sometimes with some biseriate storeys, of middle to high type, having 1-16 cells or up to 30 cells high or, 

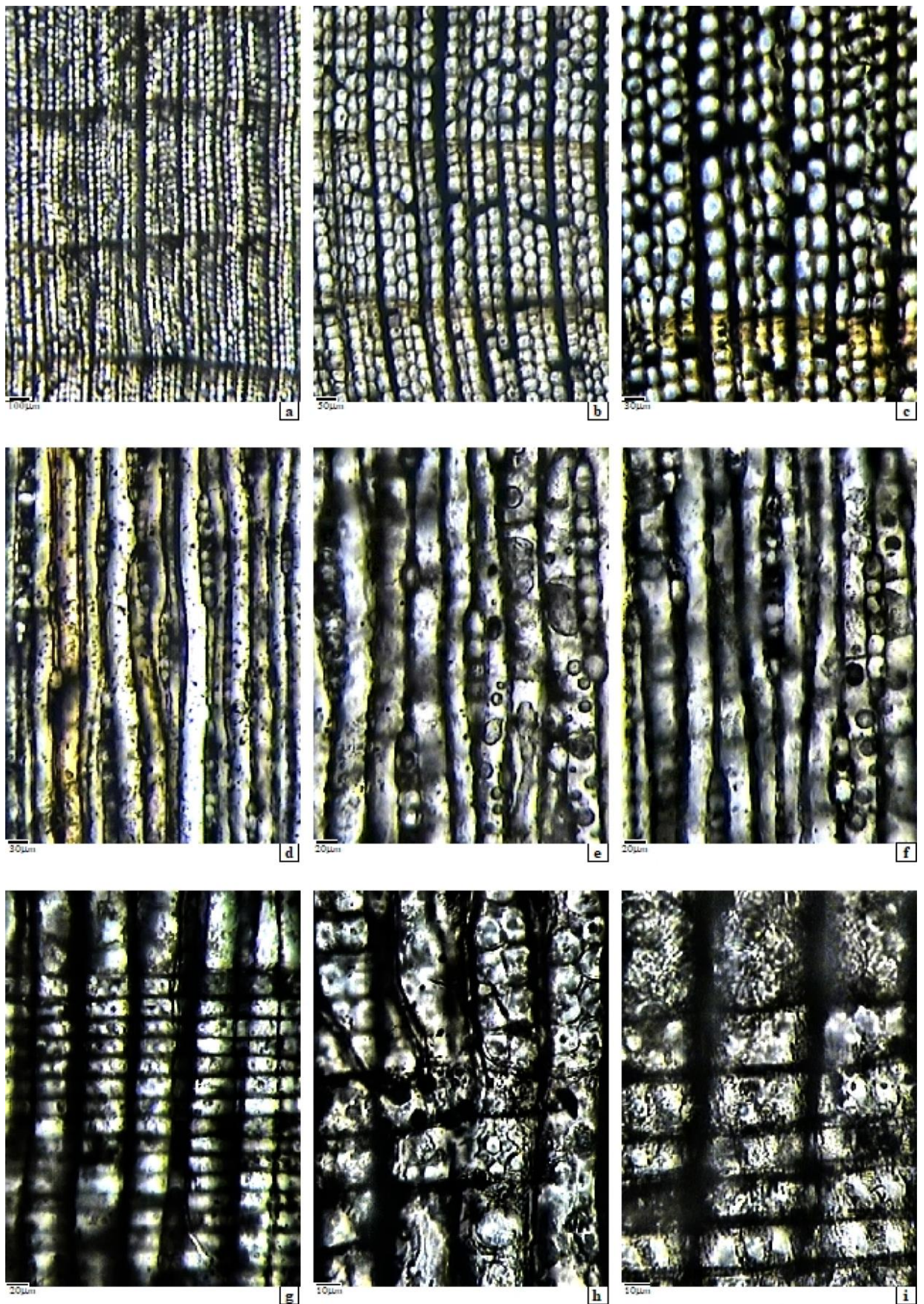

Fig. 5 a-i, (graphic scale). Taxodioxylon gypsaceum (Göpp.) Kräusel, 1949. (Specimen Lfk.313).

a-c: Cross section - quite gradual transition, distinct growth rings; parenchyma few, diffuse, or in small lines;

d-f: Tangential section - unpitted tracheids; parenchyma with end-wall smooth or weakly nodular; g-i: Radial section tracheidal pitting 1-3-seriate, opposite; rays homocellular, cells all procumbent; poorly preserved cross fields with 1-3 taxodioid pits (arrow), more numerous in taller marginal cross fields, in 2 superposed rows or slightly irregular. 
sometimes, even more than 60 cells. The ray cells, in tangential view, appear usually polygonal-rounded or oval of 12-16-20 $\mu \mathrm{m}$, rarely cribrated by small simple pits. Often lateral intercellular spaces are present. The ray-density is 6-10 rays per tangential mm. Regarding their composition, the rays are homogeneous, without ray-tracheids, having all procumbent parenchymal raycells with smooth tangential end-walls. Their horizontal walls are smooth and pitted. Indentures are not visible or are missing. The cross-field pitting is of taxodioid type, usually with 1-3 pits in one horizontal row in the normal cross fields, but up to 6 pits in the taller marginal cross fields, where they are arranged in two superposed rows. These pits appear as taxodioid oculipores of 5-8 / 8-10 $\mu \mathrm{m}$, with large to very large inclined apertures. In cross fields with axial parenchyma small cupressoid pits appear.

Resin canals - are usually absent but, sometimes, axial traumatic canals appear.

Mineral inclusions - are absent.

\section{Affinities and discussions}

The microscopic description of the studied samples of fossil wood collected from Aegean area, from late Oligocene and early Miocene sediments, showed xylotomical details that are characteristic to Cupressaceae family of "taxodiaceous" type, having radial pits on tracheids up to triseriate, opposite and with crassulae, end-wall of raycells thin and smooth and 1-3 taxodioid pits in horizontal line in the cross-fields. These xylotomical details are very specific to Sequoia wood-type (Greguss, 1955; 1967).

Fossil wood with such anatomical details was described, in time, either as Taxodioxylon (Hartig) Gothan, 1905 or as Sequoioxylon Torrey, 1923, both fossil genera being considered, in time, as valid fossil members of the former "Taxodiaceae family". Today, after advanced studies, all the "taxodiaceous genera" are incorporated in the family Cupressaceae sensu lato (Gadek et al., 2000). This family includes now 27-30 genera distributed in 7 subfamilies, some of them more exotic, like Taiwanioideae L.C. Li, Athrotaxidoideae L.C. Li and Callitroideae Saxton. The main subfamilies are: Cupressoideae Rich. ex Sweet, Sequoioideae Saxton, Taxodioideae Endl. ex Koch and Cunninghamioideae (Zucc. ex Endl.) Quinn, which comprise most the known cupressaceous taxa, living especially in the Northern hemisphere (Gadek et al., 2000; Xiang \& Li, 2005; Farjon, 2005a, 2010; Christenhusz et al., 2011).

The fossil genus Taxodioxylon was created by Hartig (1848), taking as type-species the Taxodioxylon goeppertii Hartig. This species was considerd by Philippe (1993) as equivalent to the current Sequoia sempervirens (D. Don) Endl., and this fact was admitted long before, by Gothan $(1905,1906)$, who emended first time the fossil genus Taxodioxylon. And, evaluating the structure of many previously described fossil "taxodiaceous" wood remains, it can be observed that many of them show simi78 larities, with both the genera, Sequoioxylon and Taxodioxylon, so that the separation of the two genera remained problematic for long time.

But, Kräusel (1949) has established Taxodioxylon as a comprehensive fossil genus that became a "pocketgenus" for the fossil correspondents of many current members of the former "Taxodiaceae" family, making difficult to differentiate between several taxodiaceouswood types.

Later, Greguss (1967) considered that the name Taxodioxylon should remain reserved for structures characterized by the presence of up to 8 nodular thickenings on the horizontal end-walls of the axial parenchyma, which is typical to the current Taxodium. For fossil wood of Sequoia-type he used the name Sequoioxylon as a new genus since, most probably, he hasn't $\mathrm{n}$ the published paper of Torrey (1923) and he described some new species (Greguss, 1967), transferring the species name 'gypsaceum' from Taxodioxylon to Sequoioxylon, as new combination.

However, Privé-Gill (1977) considered that the diagnosis of the Taxodioxylon-genus is sufficiently comprehensive and that establishing new areas of competence for other genera is likely to complicate the determination of fossil wood, since a great intraspecific variability can be observed even in the current genus Sequoia, especially regarding the aspect of the axial parenchyma. A consistent discussion on the nomenclatural and taxonomical treatment of the taxodiaceous wood genera is conducted by Dolezych (2011), who suggested a revision of the morphogenus Taxodioxylon, and till there she proposed to continue to use the name Taxodioxylon, with a more precise description regardind the distinct growth rings, the ray cell walls predominately smooth, the radial pitting on tracheids mostly biseriate, the presence of wood parenchyma, and the cross-field pits which are predominantely taxodioid.

- Using the table of Kräusel (1949, p. 168) in order to identify our studied specimens, in which we observed that the transverse wall of the axial parenchyma is usually thin and smooth and the cross-field pits are taxodioid or even cupressoid in the cross-fields with axial parenchyma, details which are typical also to the current Sequoia sempervirens. Such fossil wood-structure is usually identified as Taxodioxylon gypsaceum (Göpp.) Kräusel. The next presented identifications of $T$. gypsaceum are very similar to our studied specimens.

- $\quad$ van der Burgh (1973) described a T. gypsaceum and a $T$. germanicum (Greguss) van der Burgh (initially described by Greguss, in 1967 as Sequoioxylon germanicum), both considered as extinct forms corresponding to the extant Sequoia sempervirens, noting that the thin endwalls in the ray-cells could be an important differentiator to other Taxodioxylon species.

- Later, by the study of some wood specimens from the quarry Schleenhainn, Germany, near Leipzig, 
collected from an upper Eocene brown coal seam, a Taxodioxylon gypsaceum (in van der Burgh \& Meijer, 1996), which is very similar to our specimens. Here is made an interesting discussion on this species considered as a highly variable polyphyletic species, which was probably widespread in the European Cenozoic, and had a wide range of variation. However, since too few fossils wood samples have been studied to describe a fossil species, not sufficient to justify a biological variability.

- Gottwald (1992) described a Taxodioxylon sp. from the Eocene of Helmstedt, Germany, as having xylotomic details of Sequoia-type.

- $\quad$ üiss \& Velitzelos (1997) have described some species of Taxodioxylon as: T. gypsaceum, T. albertense (Penhallow) Shimakura, 1940 and T. pseudoalbertense Nishida et H. Nishida, 1985 - as stem-wood, and a new species - T. megalonissum Süss \& Velitzelos - as rootwood, which mostly resembles that of the current Sequoia sempervirens. Also, compiling about 48 Mesozoic and Cenozoic species of Taxodioxylon, they made a revision of this genus, the first one after Kräusel (1949), and they gave a new genus diagnosis, in order to include also details characteristic for the root-wood (Süss \& Velitzelos, 1997), but they did it without a corect emendation, as Dolezych (2011) observed, and it was not followed by all the palaeoxylotomists.

- Biondi, E., Brugiapaglia, E. (1991, 2000) identified some fossil woods from Dunarobba (Italy) as Taxodioxylon gypsaceum but, some xylotomical arguments point to Glyptostrobus wood-type (Martinetto, 1994; Vassio et al., 2008).

- $\quad$ Selmeier (2001), describing a fossil wood from Czech Rep., identified it as Taxodioxylon gypsaceum and said that most of the Cenozoic wood-remains (not from upper Cretaceous) assigned to this species confirm a highly variable polyphyletic species in which the pits of cross field vary from taxodioid to glyptostroboid or cupressoid.

- More recently, Teodoridis \& Sakala (2008), Koutecký \& Sakala (2015) and Koutecký et al. (2019) describing a Taxodioxylon gypsaceum (stem and rootwood) from Czech Rep., confirm the equivalence with the xylotomy of the modern Sequoia, citing Privé-Gill (1977), Dolezych \& van der Burgh (2004), Dolezych \& Schneider (2006b). In fact, they send to Sequoia woodtype or to an extinct form, Quasisequoia couttsiae (Heer) Kunzmann 1999, a species also described by van der Burgh \& Meijer (1996) from the Late Eocene of Schleenhain, Germany, in a coal-layer with the wood of Taxodioxylon gypsaceum and leaves and cones belonging exclusively to Quasisequoia couttsiae. More than this, is proposed for wood of Quasisequoia Srinivasan et Friis a genus name - Quasisequoioxylon Dolezych et Van der Burgh (in Dolezych, 2005), which would be intermediate between Cupressinoxylon Goeppert, characterized by cupressoid cross field pits and Taxodioxylon (Hartig)
Gothan, with 2-3 taxodioid cross field pits on radial tracheidal walls (Dolezych 2005: 256; Dolezych \& Schneider, 2006b).

In the same time, there were many palaeoxylologists in the world (U.S., Canada, Russia, Hungary, Romania, Ukraine, China, Turkey) who have admitted the validity of the genus Sequoioxylon Torrey 1923, and have described species under this genus name: Andrews (1936); Greguss (1967); Nagy (1969); Mathiensen (1970); Roy \& Stewart (1971); Petrescu \& Popa (1971); Petrescu \& Dragastan (1971); Petrescu \& Popa (1971); Petrescu (1978); Özgüven (1971); Blokhina (19972004); Blokhina et al. (2000); Sakınç et al. (2007); Iamandei \& Iamandei (2000, 2016, 2017); Iamandei et al. (2004; 2008a; 2012a, 2020); YiTiemei et al. (2013); Afonin (2013); Uhl et al. (2014); Tian et al. (2018); Li et al. (2018); Akkemik, (2019a); Akkemik et al., (2005, 2009, 2013, 2019acd, 2020); Acarca-Bayam et al. (2018); Özgenc et al. (2018); Güngör et al. (2019); Polat et al. (2019)

$\mathrm{Bu}$, as a conclusion, the genus name Sequoioxylon Torrey, 1923 should not be more usable, since is no more considered a valid genus (IFPNI, 2014), being in contradiction with ICN rules (Turland et al., 2018 - Shenzen Code) and all the described species under this genus must be reconsidered as species of Taxodioxylon.

Thus, our studied specimens show xylotomical characters which are very similar to those of the extant Sequoia sempervirens, having relatively wide growth rings, abrupt transition, distinct boundaries, no resin canals, (but sometimes traumatic canals can appear); tracheids polygonal in cross section, with radial pitting 1-3-seriate, as round pits of 18-22 $\mu \mathrm{m}$, sometimes slightly irregularly arranged, and with crassulae; tangential pitting usually absent; axial parenchyma in short tangential lines or in diffuse arrangement, with transverse end walls thin and smooth, rarely weakly nodular; rays exclusively uniseriate, rarely with biseriate storeys, of middle to high type, with lateral intercellular spaces, homogeneous, with smooth end-wall, no indentures, 1-3 taxodioid type pits in cross fields, or 46 in 2(-3) superposed rows. These xylotomical details are similar or almost identical to those described as on fossil wood from the European sites and identified as Taxodioxylon gypsaceum.

Based upon all these discussions which show great similarity in xylotomical features between the studied material and the species diagnosis and other published descriptions of Taxodioxylon gypsaceum, we assign our studied specimens to Taxodioxylon gypsaceum (Göpp.) Kräusel, 1949 , taking also into account the paper of Süss \& Velitzelos (1997) who described the same species, also from the Aegean area.

Taxodioxylon taxodii Gothan, 1906

Fig. 6, a-i. 


\section{Material}

Under this name were grouped 18 studied samples of silicified wood with typical taxodiaceous xylostructure. They were found either as dispersed fragments or as in situ big petrified trunks, preserved by late Oligocene to early Miocene volcano-sedimentary deposits from Aegean area, both from continental and insular part. Thus, from Evros were collected from Lefkimi the samples numbered with these field-numbers: Lfk.70, 253, 268, 269, 270 and from Trifili - the samples Tf.108, 110, 122, 126, 127, 127a, 127b. Also, some samples were collected from early Miocene of Limnos Island, numbered with Li.189, 190, 206, 208, 210, 251. The studied material is registered as "Velitzelos Collection", and stored in the Collection of the Faculty of Geology and Geoenvironment, of the NKUA.

\section{Microscopic description}

The growth rings - have variable wideness in transverse section, from low to often high (8-15 cells, to over 50 cells) with quite abrupt transition from early-wood to late-wood or, sometimes, slightly gradual. The late wood is represented by few rows of smaller cells, flattened and thick walled, the growth rings boundaries are distinct, whereas usually the early wood always starts with larger and with thinner-walled cells.

The tracheids - are in polygonal cross-section, often rectangular and with rounded corners, are sometimes deformed by compression. In the early-wood, they have the radial / tangential diameters of 20-50 / 17-40 $\mu \mathrm{m}$ and wall thickness of 4-7 $\mu \mathrm{m}$ (double wall); in the transitional wood, when present, the diameters are quite similar, diminishing in size slightly gradually toward the late-wood, which is represented by (3-)5-7 rows of tracheids with smaller lumens, with diameters of 8-17 / 10-15 $\mu \mathrm{m}$, and thick walls of $8-12 \mu \mathrm{m}$ (double wall) in the final wood. Between two successive rays there are 2-9 radial rows of tracheids, regularly arranged. Intercellular spaces are often present. Tracheid density is (980-)1600-1716 tracheids per $\mathrm{mm}^{2}$. However, the tracheid length is difficult to measure. The tracheid pitting on radial walls appear uniseriate or biseriate, spaced and oppositely arranged. The pits are of bordered type, round shaped, 18-21 $\mu \mathrm{m}$ in diameter, with large chambers and round and large elliptic aperture. Torus less visible. On the tangential walls pitting is usually missing, or it appears sometimes as uniseriate, smaller, round, bordered pits, of $12-15 \mu \mathrm{m}$ in diameter, sometimes slightly irregularly arranged. Helical thickenings on tracheids are not present but, sometimes, striations can appear on the slightly bent endings. Crassulae are absent. Callitroid thickenings - absent. Organic deposits absent.

The axial parenchyma - present and appear in cross section few, in diffuse arrangement, scattered throughout the entire growth ring, as smaller cells, usually with dark content. In longitudinal sections, the string of parenchyma cells shows transverse end walls, thick of $2-5 \mu \mathrm{m}$, 80 nodular with up to 8 bead-like knots or even denticles, often badly preserved. Inside the cells a resin content can appear, as black globules or granules, or as plugs, or compact and with convex empty spaces.

The rays - are exclusively uniseriate, and in tangential sections appear sometimes with some biseriate storeys up to almost biseriate; they are of low to middle type (from 1-3 to 7-15 cells) or of taller type (of 16-30 cells, sometimes more). In radial section the rays are homogeneous, with parenchymal ray-cells all procumbent, of 16-20 $\mu \mathrm{m}$ tall, the marginals being usually taller (up to $24 \mu \mathrm{m}$ ), and without ray tracheids. The horizontal walls of the ray cells are thick, the double-wall has 5-8 $\mu \mathrm{m}$, smooth and pitted (they are not ray tracheids). The tangential endwalls are thick, of $3 \mu \mathrm{m}$ simple-wall, smooth or slightly rugose or nodular, straight or inclined or arcuated. Indentures were not observed or are missing. The cross fields have 1-2(-4) taxodioid pits, arranged in horizontally pairs or superposed in the taller cross fields. These pits are oculipores of taxodioid type, of (7-)9-12 $\mu \mathrm{m}$, with large inclined apertures, rarely with cupressoid or glyptostroboid aspect. Globules of resin or granules are often present inside the ray-cells.

Resin canals - are absent.

Mineral inclusions - are not present.

\section{Affinities and discussions}

The synthetic xylotomical description of the 18 studied specimens, showed a characters' combination similar to the "taxodiaceous" wood type from Cupressaceae family, namely the absence of resin canals, biseriate radial pitting on tracheids, the nodular transverse end wall of the axial parenchyma and the cross field pitting typical taxodioid, xylotomical details which characterise the current Taxodium wood-type (Fairon-Demaret et al., 2003; Dolezych and van der Burgh, 2004; Phillipe \& Bamford, 2008; Dolezych, 2011; Ibrahim, 2015). Advanced genetic and morphologic studies on the members of Cupressaceae family (discussion above) allowed a better organization of them, distributed now in seven subfamilies (Gadek et al., 2000; Farjon, 2005). The former "taxodiaceus" genera are now redistributed (discussion above), and the Taxodioideae subfamily includes only three genera with disjunct living-area in North America and East Asia: Taxodium Rich. Cryptomeria D. Don. and Glyptostrobus Endl. (Gadek et al., 2000; Farjon, 2005; Schulz \& Stützel 2007; Mao et al., 2012).

- Regarding the "taxodiaceous" fossil wood, we have presented above the fossil genus Taxodioxylon Hartig 1848, whose type species T. goeppertii Hartig was considered an equivalent to Sequoia sempervirens (Gothan,1905, 1906; Philippe, 1993). However, Kräusel (1949) established the genus Taxodioxylon for taxodiaceous fossil wood, and it became a "pocket genus" for many fossil correspondents of many current members of the former "Taxodiaceae" family (Dolezych, 2011). 

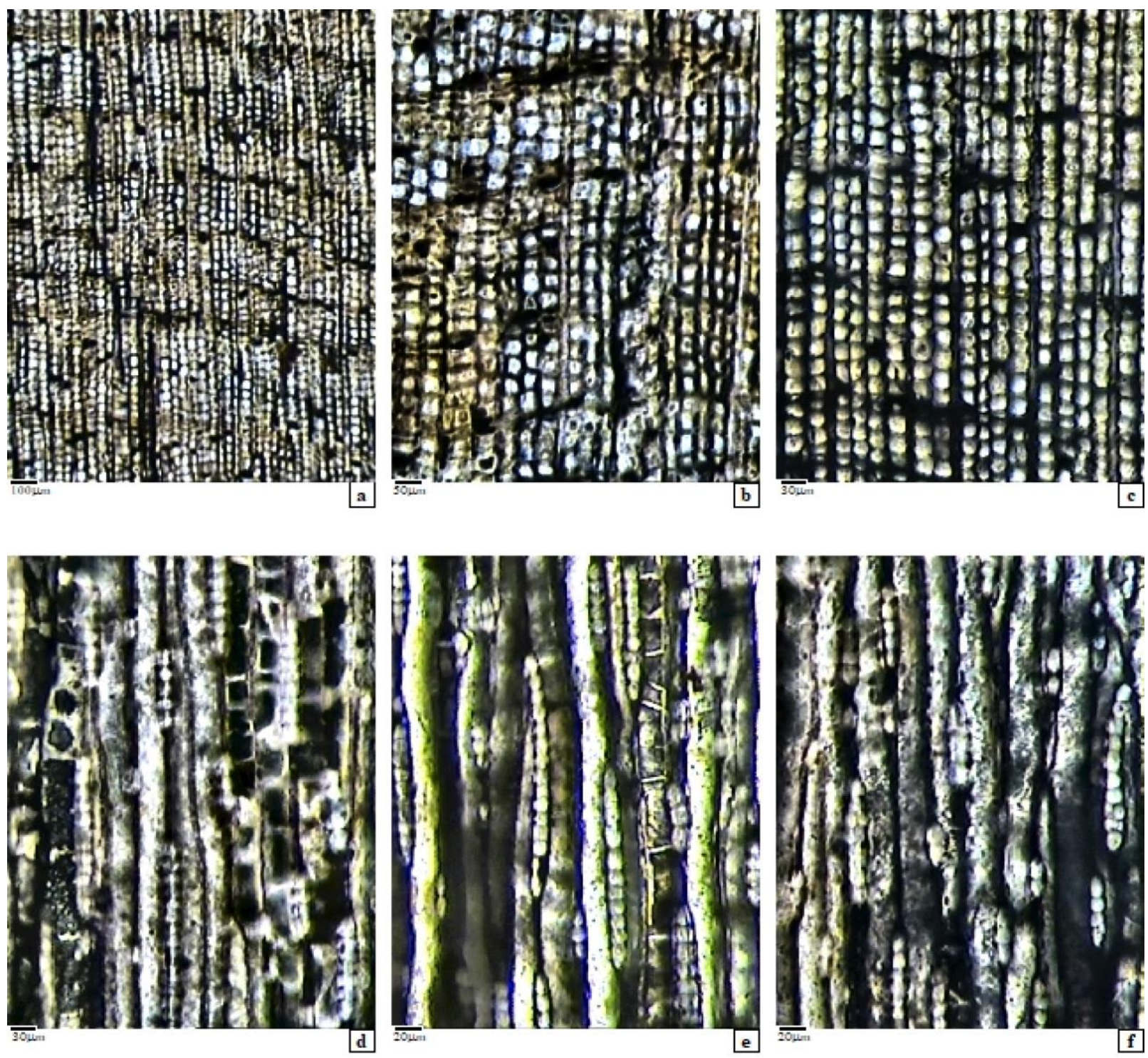
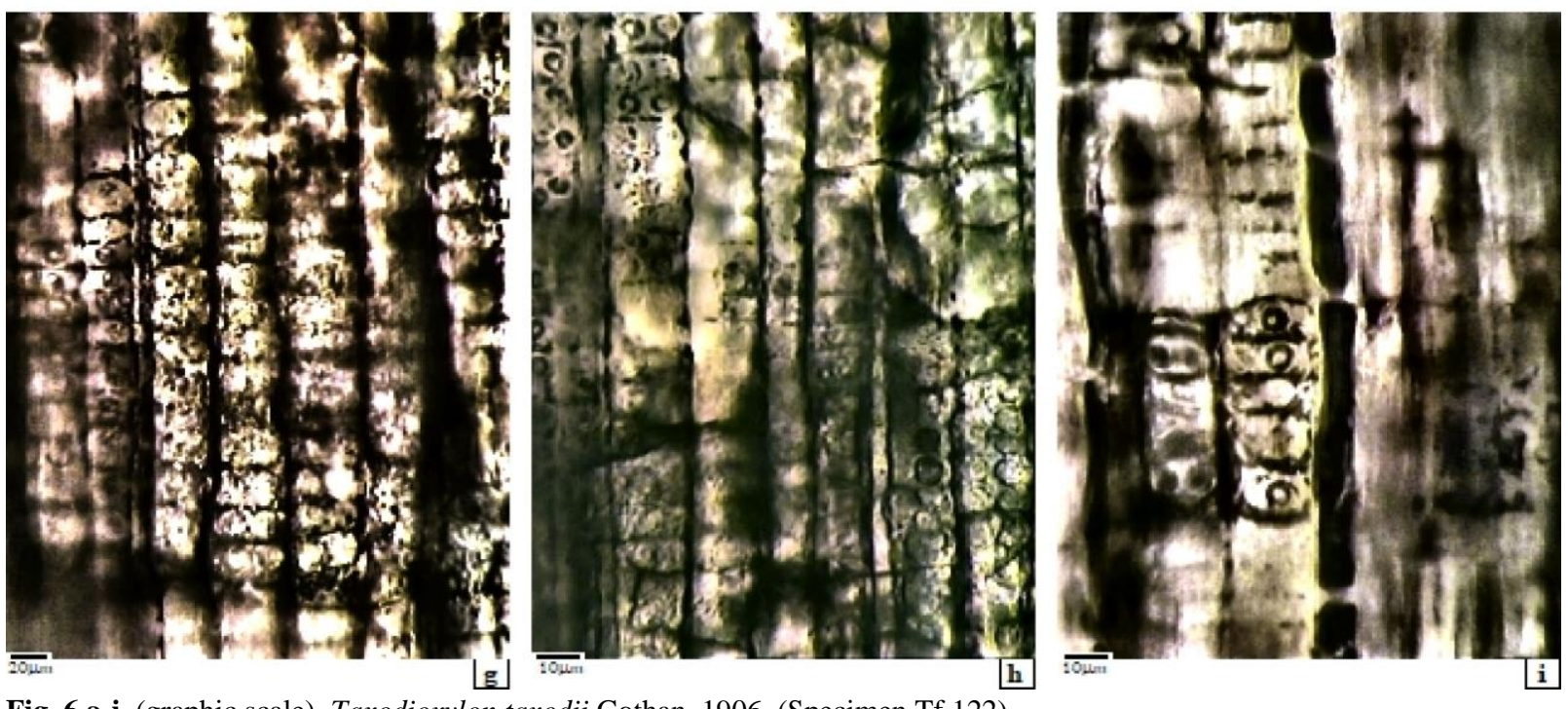

Fig. 6 a-i, (graphic scale). Taxodioxylon taxodii Gothan, 1906. (Specimen Tf.122).

a-c: Cross section - quite gradual transition, distinct growth rings; large tracheids; parenchyma few, diffuse; d-f: Tangential section - pitting on tracheids absent; axial parenchyma end-walls nodular (arrow); rays uniseriate; g-i: Radial section - tracheidal pitting 1-2-seriate, pairs opposite; rays homocellular, cells all procumbent; poorly preserved cross field pitting with 1-2(4) taxodioid oculipores. 
- Greguss (1967) considered that the name Taxodioxylon should remain reserved for structures characterized by the presence of numerous nodular thickenings (up to 8) on the horizontal end-walls of the axial parenchyma, which is typical to the extant genus Taxodium.

- But Privé-Gill (1977) considered the diagnosis of the Taxodioxylon-genus as sufficiently comprehensive, therefore establishing new areas of competence for other genera could complicate the determination of fossil wood.

- A much-documented discussion on the fossil cupressaceous xylotaxa, especially on Taxodioxylon genus, is made by Dolezych (2011), who also proposed a revision of it.

- Anyway, despite some confusion inside the Taxodioxylon fossil genus concerning its modern affinities (Fairon-Demaret et al., 2003; Dolezych \& van der Burgh, 2004, Phillipe \& Bamford, 2008; Dolezych, 2011), the generic identification of the studied material here is correct and the described xylotomical details corespond to those described for Taxodioxylon taxodii by Gothan (1906), a fossil species often present in the coal-deposits as an important Cenozoic coal-generator tree and often identified in Europe (Zalewska,1953; Greguss, 1967; Gottwald,1966, 1992; Selmeier, 2001; Iamandei \& Iamandei, 2000b, 2017; Iamandei et al., 2001b,c; 2005a; 2008b,c; 2012b; Teodoridis \& Sakala, 2008; Akkemik et al., 2009; Uhl et al., 2014). It has usually 1-2-seriate pitting on the radial walls of the tracheid, nodular end-walls of the axial parenchyma and cross fields with 1-2(-4) taxodioid pits.

In a synthetic description all the here studied specimens show distinct growth rings without resin canals, tracheids with 1-2-seriate radial pits, without crassulae, diffuse parenchyma with nodular transverse end-walls (with up to 8 knots), uniseriate homogeneous rays, ray cells with nodular end-walls and cross fields with 1-2(-4) taxodioid pits, details that perfectly fit to the diagnosis of the classic species of Gothan, Taxodioxylon taxodii.

Thus, based on all the above discussions on the possible affinities and on the comparison with other descriptions of fossil wood of Taxodium-type, from Kräusel (1949) to Greguss (1967), up to Dolezych \& van der Burgh (2004) and Dolezych (2011), we assign all the 18 studied specimens to the species Taxodioxylon taxodii Gothan, 1906.

We also note the fact that Dolezych (2011) affirms that this fossil species, T. taxodii Gothan, appears to be the closest to current Taxodium mucronatum Ten., not only because of the small difference in cross fields where cupressoid pits can appear (or not), but also by the habitat type, as a coal-generating species.

Genus Glyptostroboxylon Conwentz emend. Dolezych \& van der Burgh, 2004

Glyptostroboxylon rudolphii Dolezych \& van der Burgh, 2004
Fig. 7, a-i.

\section{Material}

The studied material is represented by 36 samples of petrified wood, collected from the Aegean area, both from insular and continental part. Thus, some of them were collected from Evros region, from late Oligocene deposits, from Lefkimi - the samples Lfk.1, 56(3), 152, 255, 256, 257, 258, 262, 263, 273, 284, 288 and from Trifili the samples Tf.5, 9, 15, 23, 27, 45, 47, 50, 137, 309, 314. Also, some samples were collected from early Miocene deposits of Limnos island - the samples numbered with Li.131, 132-2, 205, 471, 474, 474-14, 480, 481, and from Lesbos Island - the samples Lsv.45, 112, 428, 455 and 470 .

The studied material is registered as "Velitzelos Collection", and stored in the Collection of the Faculty of Geology and Geoenvironment, of the NKUA.

\section{Microscopic description}

Growth rings - are variable, from low to wide (i.e. from $8-15$ cells to over 50 cells), usually with quite abrupt transition from the early-wood to the narrow late-wood, which has 2-3-5 rows of smaller flattened cells, so, the growth rings boundaries are quite distinct, since always the early-wood starts with larger cells. Normal axial resin canals absent.

Tracheids - have polygonal lumen in cross-section in the early-wood, with radial / tangential diameters of (20-)35$60 /(17-) 30-40 \mu \mathrm{m}$ and the wall thickness of 3-6 $\mu \mathrm{m}$ (double wall); in the late-wood the diameters are quite similar, only in the final 1-3 rows, the tracheids are diminishing, having 8-15/10-15 $\mu \mathrm{m}$ in diameters, and the wall thickness reach 7-9 $\mu \mathrm{m}$ the double wall. The tracheids, in cross section, appear regularly arranged in 2-9 radial rows between two successive rays, and intercellular spaces are often present. The density is 1300-1700 tracheids per $\mathrm{mm}^{2}$. The length of the tracheids is medium to large type, but difficult to measure. The pitting on the radial walls is 1-4 seriate, spaced, in opposite arrangement and often with crassulae. The pits, of bordered type, are round, with (12-)15-20 $\mu \mathrm{m}$ in diameter, with large chamber and round to slightly elliptic aperture. On the tangential walls, few uniseriate smaller pits of 8-9 $\mu \mathrm{m}$ in diameter appear, sometimes localy irregularly biseriate. Helical thickenings absent, but striations sometimes are present on the endings which, sometimes, can be slightly bent. Crassulae sometimes present and, when present, the pits are located in a kind of nest and are slightly molded by the tracheidal wall. Callitroid thickenings not present. Organic deposits absent.

Axial parenchyma - is present and appear in cross section as few smaller cells, in diffuse arrangement, scattered throughout the entire growth ring and usually with some dark content. 

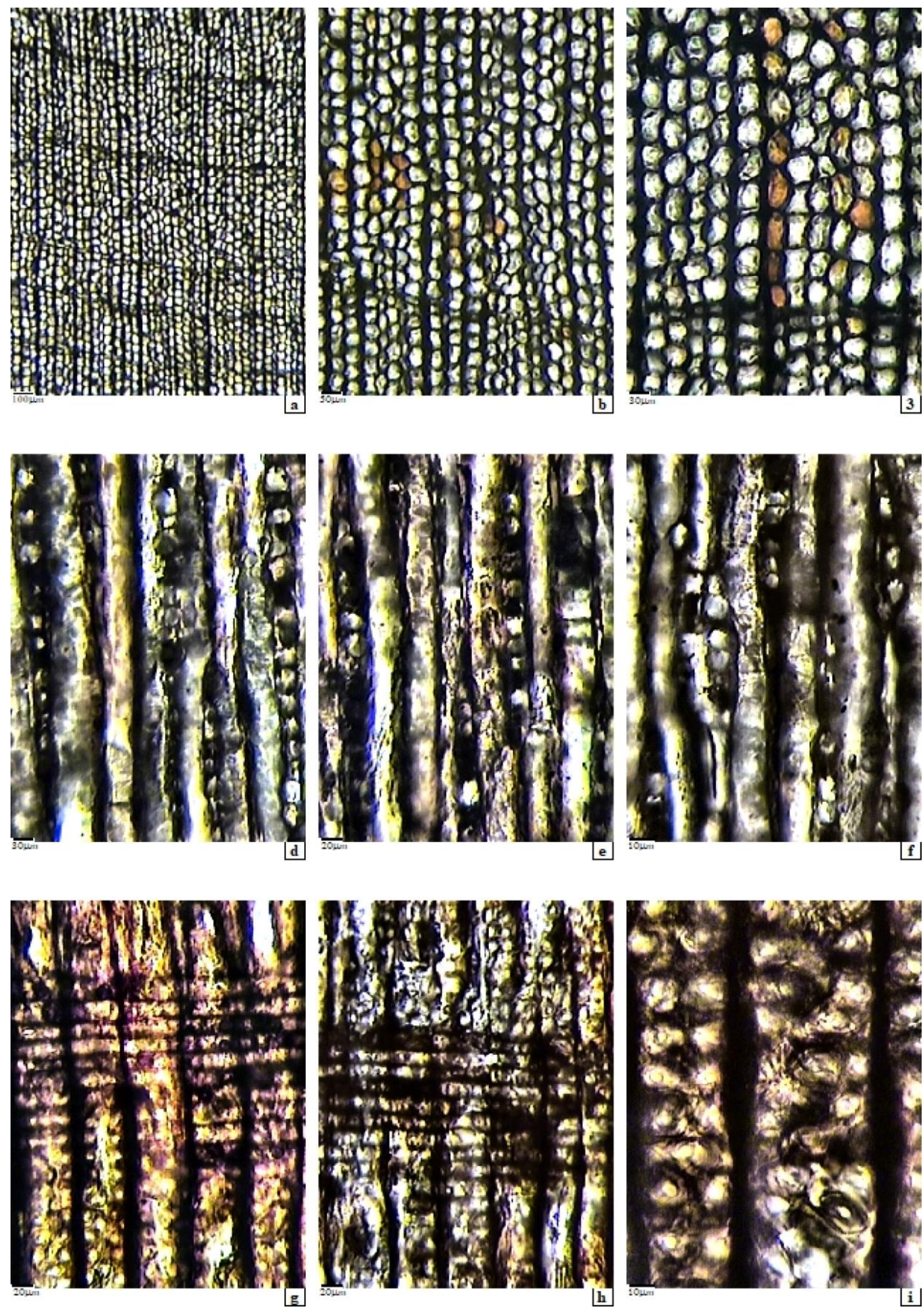

Fig. 7 a-i (graphic scale). Glyptostroboxylon rudolphii Dolezych et van der Burgh, 2004; (Specimen Li.481)

a-c: Cross section - abrupt transition, quite distinct growth rings; thick-walled tracheids; d-f: Tangential section - few pits on tracheids, parenchyma with nodular transverse wall; rays exclusively uniseriate; g-i:. Radial section - radial pitting 1-3seriate, opposite; rays homogeneous, parenchymal cells sll procumbent, marginals taller; poorly preserved cross-fields with 1-4 glyptostroboid to taxodioid pits (arrows). 
In vertical section, the string of parenchyma cells shows transverse end-walls thin and smooth to moderately nodular, and also resin content as rare small and black globules or granules, inside.

Rays -appear linear and thin in the cross sections, usually exclusively uniseriate. In tangential section they appear sometimes with biseriate storeys to almost biseriate. Lateral intercellular spaces are often present. The rays are of low type, having 1-10 cells, to mid type, with up to 20 cells, sometimes taller. In radial section the rays are usually homogeneous, with parenchymal ray-cells all procumbent, the marginals taller. The horizontal walls of the ray-cells are smooth, with simple pits, and the end-walls are smooth. Indentures - not visible. The cross-field pitting is of glyptostroboid type, usually having glyptostroboid pits or, sometimes, taxodioid, of 10-12 $\mu \mathrm{m}$, with round to large-eliptic appertures. They appear as 1-4 pits in one horizontal row in normal cross fields, or 4-6 pits in the taller cross fields, when they are in 2 superposed rows or slightly irregularly arranged. In the late-wood cross fields the pits tend even to cupressoid type as smaller pits, of 6-8 $\mu \mathrm{m}$, and with inclined lens-like apertures. Sometimes, globules or granules of resin are present inside the ray cells.

Resin canals - are absent.

Mineral inclusions - are absent.

\section{Affinities and discussions}

The synthetic description of the above specified 36 specimens provided xylotomical details typical for a cupressaceous wood of 'taxodiaceous' type, caracterized by absence of the resin ducts, cross-section and wallthickness of the tracheids and especially by the presence of radial pitting as 1-4-seriate on tracheids, sometimes with crassulae and the cross-field with typical glyptostroboid pits, tending sometimes to taxodioid or even cupressoid aspect. These xylotomical details have been compared with other extant or fossil structures of 'taxodiaceous' type, as published by Greguss (1955), Visscher \& Jagels (2003), InsideWood (2004 - onwards), Dolezych \& van der Burgh (2004), Dolezych (2011) and Wheeler (2011) that suggested us the most possible affinity to Glyptostrobus wood-type. This genus belongs to the family Cupressaceae (s.l.), subfamily Taxodioideae Endl. ex K. Koch - together with Taxodium Rich. and Cryptomeria D. Don, as is presented above. The current Glyptostrobus Endl. has a single species living in a disjunct area in East Asia: G. pensilis (Staunton ex D. Don) K. Koch, (Chinese swamp cypress) in subtropical southeastern China ( $\mathrm{Fu}-$ jian, Yunnan) and locally, in northern Vietnam and eastern Laos (Lao PDR) (Greguss, 1955; Earle, 2018).

It typically grows in river banks, ponds and swamps, even in water up to $60 \mathrm{~cm}$ deep, similar to the related genus Taxodium, having also 'cypress knees' which help the roots to breath. Arguably even before, but surely during the Cenozoic, the distribution of these genera was different than today, they were present in Europe, from 84 where a lot of fossilized wood remains and other vegetative plant parts were found and described. Often, these genera were deeply implied within coal-genesis, the fossil forms of Taxodium and Gyptostrobus probably had a typical and similar behaviour as today preferring the wet environments or even swamps, or peat-bogs (Greguss, 1955; Earle, 2015).

Also, comparing the anatomical structure of the studied specimens with other 'taxodiaceous' fossil genera (Greguss, 1967) we observed some similarities also with the fossil forms of Taxodioxylon (Hartig) Gothan, but especially with Glyptostroboxylon Conwentz, 1884. In fact, the distinction between these fossil genera is sometimes problematic enough, as they have many similar xylotomical details. But, in a more recent revision of these fossil cupressaceous morphogenera (Dolezych \& Van der Burgh, 2004) the authors tried to solve this problem and created a new species of Glyptostroboxylon by reviewing the original material described by Kraus (1864), from Wetterau, which was found as comparable with the wood of modern Cunninghamia R.Br. (Dolezych, 2011), so emending the genus diagnosis. We reproduce here the diagnosis of the genus Glyptostroboxylon Conwentz, emend. Dolezych \& van der Burgh, 2004: "Coniferous wood with distinct growth rings. Tracheids in the earlywood wider than in the latewood. On the radial walls of tracheids, pits in 1-3(4) vertical rows. Wood parenchyma with thin and smooth to moderately thick and pitted terminal (horizontal) walls. Rays are homogeneous, mostly uniseriate. Cross-field pits in the early wood are predominantly glyptostroboid, but also some cupressoid and taxodioid pits may be present".

In our studied specimens we observed and described very similar details regarding the shape of the tracheids in cross-section and their radial pitting as 1-2 to 3-4 vertical rows, spaced or sometimes slightly irregularly arranged; then, the presence of axial parenchyma with smooth to slightly nodular horizontal walls; and the rays, which are uniseriate, often with biseriate storeys, or even as biseriate rays, homogeneous with ray cells all procumbent, tangential walls smooth, and no ray-tracheids; the crossfields with 1-4 glyptostroboid pits, sometimes tending to taxodioid, more numerous in the marginal fields which are taller and the pits are smaller cupressoid pits arranged in two horizontal rows or slightly irregularly. Such description corresponds to the genus diagnosis.

- Dolezych \& van der Burgh (2004), in their revision of Glyptostroboxylon genus, showed that the species Glyptostroboxylon tenerum (Kraus) Conwentz was the initial basionym for the genus (whose former name was Glyptostrobus tener Kraus, 1864). This basionim was commented by Seward (1919, p. 198) and by Jurasky (1933), and corrected by Kraüsel (1949), respecting he ICBN Rules of that time. However, he noted the wide variability of the glyptostroboid pits in the cross fields, toward taxodioid or cupressoid type. Now, Glyptostroboxylon tenerum is interpreted as fossil wood of Cun- 
ninghamia. In fact, it was known that Gothan (1905) and later, Rudolph (1935), Watari (1948), Süss \& Velitzelos (1997) and Fairon-Demaret et al. (2003) have observed an affinitiy between the wood of Glyptostroboxylon tenerum and that of the current Cunninghamia, and the new investigation on the original material from Wetterau, the type-locality, made by Dolezych \& van der Burgh (2004), have proved that the affinity of this wood is not to Glyptostrobus, but clearly to Cunninghamia ( also Dolezych, 2011).

- In the same paper Dolezych \& van der Burgh (2004) described a new species, Glyptostroboxylon rudolphii Dolezych \& van der Burgh, designating it as new basionym for the genus Glyptostroboxylon Conwentz emend. Dolezych \& Van der Burgh 2004 (cited above, the emended diagnosis). The species name come from the name of a scientist who, first time discussed the affinity of the described fossil wood as Glyptostroboxylon as being to the recent wood of Glyptostrobus not of Cunninghamia (Rudolph, 1935), observing that the pits in cross field of the studied fossil wood are glyptostroboid and taxodioid, in a random distribution. This new species described, Glyptostroboxylon rudolphii, represents, most probably, the fossil wood of Glyptostrobus europaeus (Brongniart) Unger, which was described on the basis of adpressions of shoots, leaves and cones, and was frequently found in the European Cenozoic formations (Greguss, 1967; Hofman, 1952; Ramanujam, 1960; Zalewska, 1953). Together with their revision of Glyptostroboxylon genus, Dolezych et van der Burgh (2004) described more material of "taxodiaceous wood" in Lusatia (Central Europe) with clear affinity to the current Glyptostrobus. Also, they suggested that many other descriptions of similar coniferous woods previously described by Kräusel (1949), Schönfeld (1952), Kostyniuk (1967), Visscher \& Jagels (2003), van der Burgh (1973), could be revised and assigned to Glyptostroboxylon rudolphii.

- Teodoridis \& Sakala (2008) identified a Glyptostroboxylon rudolphii, and observed the disproportion between the abundance of leaves and cones and ds of Glyptostrobus in Most Basin (Czech Republic), and only one specimen of fossil wood found preserved as xylite, rather difficult to identify and attributable to this genus, traditionally considered as the main coal-generating element in "the association of Glyptostrobus" sensu Kvaček \& Bůžek, 1982 (in Kvaček, 1999 and in Teodoridis \& Sakala, 2008, p.304).

- Biondi \& Brugiapaglia (1991) described a Taxodioxylon gypsaceum on a specimen from the Pliocene of Umbria region, central Italy, having commonly with 4seriate bordered pits on the radial walls of the tracheids, presumably in early wood and also, axial parenchyma with smooth horizontal walls. In a later work, refering to the same material, Biondi \& Brugiapaglia (2000) affirm that the 4-seriate bordered pits are rare, and they are mostly 1 - to 2 -seriate, and suggested that the wood anatomy of the Dunarobba wood could be similar to the one of the current Sequoia. However, Martinetto (1994) pointed out that in the Dunarobba deposits the conifer foliage, ds and cones belong uniquely to Glyptostrobus europaeus, so we think that a revision of the fossil wood of Dunarobba Fossil Forest is necessary, since we believe that we talk about Glyptostroboxylon rudolphii (also Vassio et al., 2008).

- Also, Ravazzi \& Van der Burgh (1995) have identified several wood samples from the Leffe brown coal (Early Pleistocene, N-Italy), and some specimens that were assigned to Glyptostroboxylon tenerum (Kraus) Conwentz, found together with pollen of Glyptostrobus, Chamaecyparis, Picea and Pinus. However, the Leffe wood identifications would need revision too ( Vassio et al. 2008), because the described wood shows some characteristics that point to Glyptostroboxylon rudolphii: in the radial walls of earlywood tracheids bordered pits are biseriate, crassulae are present, rays are uniseriate and up to 22 cells high; cross field pits vary from cupressoid to taxodioid and to glyptostroboid ( Fairon-Demaret et al., 2003; Richter et al., 2004).

- Some Miocene fossil wood remains described by Iamandei et al. (2001) from Eastern Carpathians (Leucuşeşti-Fălticeni) and by Nagy et al. (2002) from South Apuseni Mts. (Prăvăleni) were identified as Glyptostroboxylon tenerum, but having cross fields with 3-4(6) glyptostroboid pits, most probably must be revised to Glyptostroboxylon rudolphii.

- Teodoridis \& Sakala (2008) have studied a fragment of sideritized wood from Bílina Mine, from the Most Basin, described as G. rudolphii, having crassulae, large intercellular spaces between ray-cells and crossfield pits exclusively glyptostroboid.

- $\quad$ Vassio et al. (2008), also described G. rudolphii from Middle Pliocene, studying the in-situ stumps from Stura di Lanzo right riverbank, NW Italy, based on their typical features, especially the presence of exclusively glyptostroboid cross-field pits.

- Dolezych (in Erdei et al., 2009), studied the stumps from the Miocene Fossil Forest from the opencast lignite mine of Bükkábrány (Hungary) and described wood structures atribuable to Glyptostroboxylon Conwentz emend. Dolezych and van der Burgh, as having glyptostroboid cross field pits. This fact is confirmed also by the presence of the organic-rich sediments underlying and embedding the stumps, which provided a high abundance of wood remains, foliage, cones and ds of Glyptostrobus.

- $\quad$ Gryc \& Sakala, (2010), studied also the xylotomy of the big trunk of fossil wood found in the Miocene opencast lignite mine of Bükkábrány (Hungary) and exposed in the Visitor Centre of the Ipolytarnóc Fossils Nature Reserve and, have identified it as Glyptostroboxy- 
lon rudolphii, having cross-field pits, mainly glyptostroboid.

- Dolezych (2011) made new xylotomical investigations in the Miocene peat formation in Lusatia trying to reconstruct the woody plant communities and described again the presence of $G$. rudolphii with its typical xylotomical features, besides other taxa.

- Havelcová et al. (2013) have described a G. rudolphii, in the Stump Horizon from the Bílina open cast mine (Czech Republic), as having the typical glyptostroboid pits in the cross-fields.

- Koutecký \& Sakala, (2015) described G. rudolphii from Doupovské hory, Czech Republic, as having glyptostroboid and taxodioid pits (1-2, occasionally up to 4) in cross-field, and low rays, up to 12 cells tall.

- The fossil wood remains signalled by Mustoe (2018) at high latitudes of North America (from Yukon to Elsemere Island and around), were studied by Dolezych et al. (2018) who described more Cretaceous - Paleogene conifers, and between them a Glyptostroboxylon cf. rudolphii and also, a G. tenerum.

- $\quad$ Li et al. (2018), described a new species, a wood from the Paleocene of Carneyville, Wyoming (US) as Sequoioxylon carneyvillense Li, Jin et Manchester but having cross-fields with 1-4 taxodioid pits and being associated with twigs, fossil leaves and d cone remains, identified as of Glyptostrobus europaeus, we presume it could be a wrong identification, and it is probably a Glyptostroboxylon rudolphii.

- Recently, Akkemik et al. (2017) published a Glyptostroboxylon (of rudophii type) from central Turkey, and then Akkemik et al. (2018; 2019a,b; 2020b) identified $G$. rudolphii from another sites in Turkey, based on the typical features such as 2-5 pits per cross field, predominantly glyptostroboid, but also taxodioid and, apparently, much higher rays.

- Very important, Mantzouka et al. (2019a) found, presented and redescribed the original material of the holotype of Glyptostrobus europaeus, housed in the collections of the Muséum National d'Histoire Naturelle, Paris, originally collected from the Alonissos Island, Greece, an also, they show that such fossil remains of Glyptostrobus europaeus have been described in several localities in Greece during the Cainozoic up to Pleistocene.

- $\quad$ And, in a recent study on some Miocene material from Bozovici area (SW Romania) was described by Iamandei et al. (2020b) a Glyptostroboxylon rudolphii, as having typical tracheidal radial pitting 1-4-seriate, and 14 glyptostroboid and taxodioid cross-field pits, in horizontal row.

Thus, after this discussion, and based on the synthetic description of a numerous population of samples (39 specimens) collected from the Aegean area, it is obvious that there is a great similarity of the xylotomical characters of our studied specimens with those comprised in the generic and specific diagnosis, and with those showed by the numerous previous identifications, discussed above, as well as with the characters of the curent correspondent, we attribute all the studied specimens to Glyptostroboxylon rudolphii Dolezych et van der Burgh, 2004, as a perfect fossil equivalent of the extant living fossil Glyptostrobus Endl.

\section{Glyptostroboxylon tenerum (Kraus) Conwentz 1884}

Fig. 8, a-i.

\section{Material}

The fossil material studied, represented by 53 samples of silicified wood, comes from Aegean area - insular and also continental part. Thus, some of them were collected from Evros, from late Oligocene volcano-sedimentary deposits, from Lefkimi - the samples with the field numbers Lfk.153, 155, 157, 166, 174, 190, 191, 254, 264, 271, 275, 283, 290, 291, 292, 293, 295, 296, 297, 299, 301, 302, 308, 310, 318, 321a, 321b, 325, 328b, 333; and from Trifili - the samples Tf.1, 2, 7, 9a, 14, 16, 30, 109, 119. Also, other samples were collected from early Miocene volcano-sedimentary deposits from Limnos Island the samples Li.187, 193, 194, 197, 200, 209, 230, 236, 467, 469, 473, 483, 484, 485a. The studied material is registered as "Velitzelos Collection", and stored in the Collection of the Faculty of Geology and Geoenvironment, of the NKUA.

\section{Microscopic description}

Growth rings - show a variable width, from low to often large of over 50 cells, with quite abrupt transition, even if sometimes a gradual size diminution is visible, from the early-wood to the late-wood, which is represented by 2-5 rows (sometimes more) of smaller flattened cells, and the growth rings boundaries are quite distinct, since the early woodalways starts with larger cells. Normal resin canals are absent.

Tracheids - have a polygonal cross section, sometimes deformed by compression. In the early-wood, they have the radial / tangential diameters of the tracheids of 20-35 (60) / 17-30 (45) $\mu \mathrm{m}$ and are not too thick walled, having 3-6 $\mu \mathrm{m}$ (double wall); in the late wood the diameters are between 8-15 / 4-15 $\mu \mathrm{m}$ (r/tg d.) and the wall thickness reach 7-10 $\mu \mathrm{m}$ (double wall). The cells are regularly arranged in 2-9 radial rows between two successive rays, and intercellular spaces are often present. The density is between 1200-1700 tracheids per $\mathrm{mm}^{2}$. Tracheid length difficult to measure, and sometimes, at cross fields meeting, the tracheids are bent. Radial pitting is usually uniseriate, sometimes biseriate, spaced, opposite, but often loosely arranged, partly touching each other. The pits, of bordered type, are round, with 10-18(-20) $\mu \mathrm{m}$ in diameter, with ornate chambers, apertures sometimes notched. Torus less visible. In tangential view uniseriate pits appear, small, of 9-10 $\mu \mathrm{m}$ in diameter, sometimes larger and slightly irregularly arranged. Helical thickenings absent, 

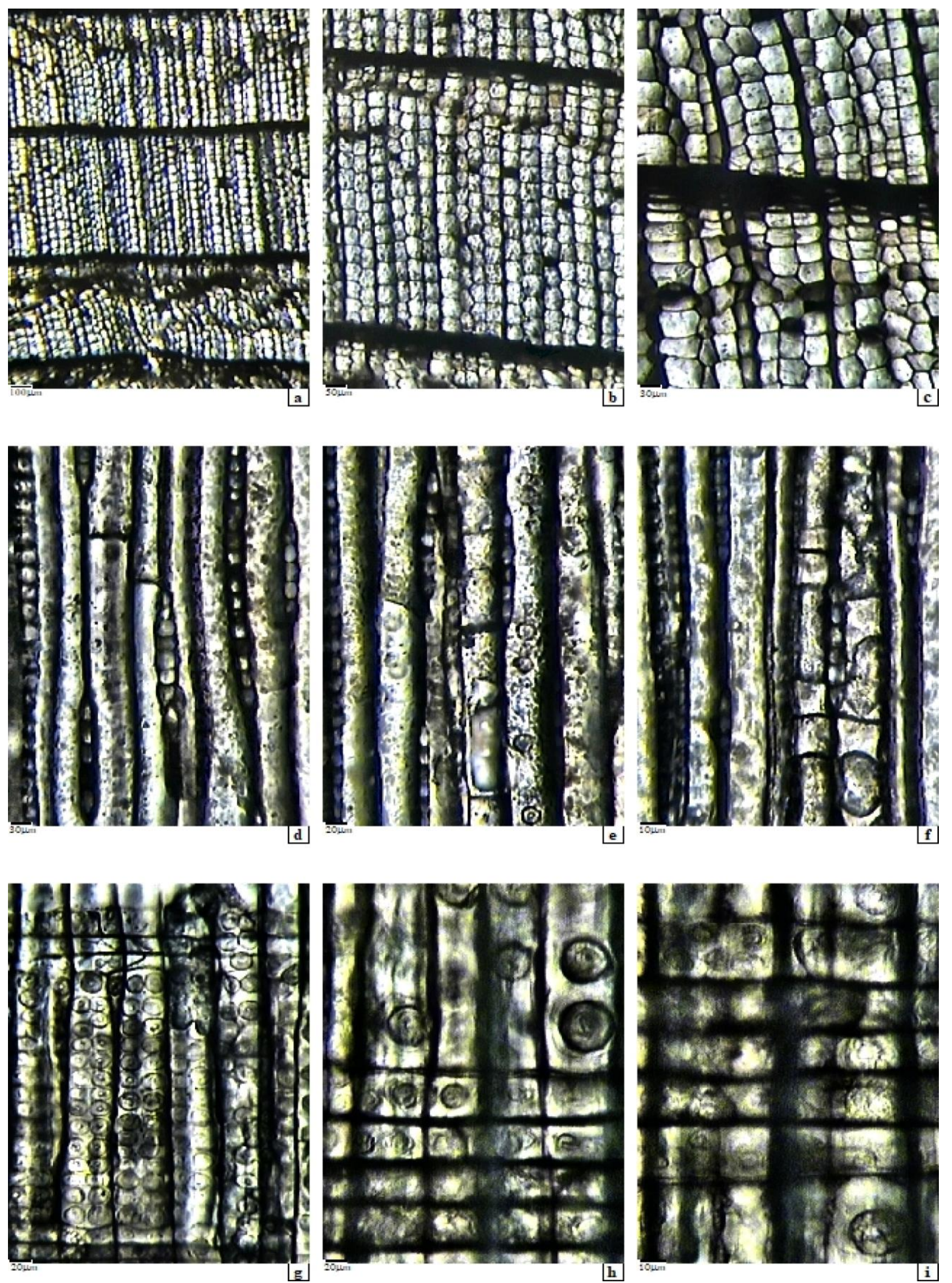

Fig. 8 a-i, (graphic scale). Glyptostroboxylon tenerum (Kraus) Conwentz, 1884; (Specimen Li.483).

a-c: Cross section - quite abrupt transition, distinct growth rings; large thin-walled tracheids; parenchyma few, diffuse; d-f: Tangential section - irregular uniseriate small pits on tracheids; parenchima with nodular end walls (arrow); rays exclusively uniseriate; g-i: Radial section - tracheidal pitting 1-2-seriate, opposite; rays homocellular, cells all procumbent; cross field with 1-2(-3) cupressoid pits or taxodioid (arrows), more numerous in marginal cross fields, and slightly irregular. 
but striations sometimes are present. Crassulae sometimes present. Often, the pits are located in a kind of nest and are slightly rounded by the tracheidal wall. Callitroid thickenings absent. Organic deposits absent.

Axial parenchyma - appear in cross section as few, dark, smaller cells and diffusely arranged, scattered or as short tangential lines. In longitudinal section the vertical string of cells shows transverse walls thin and smooth, sometimes nodular. Also, resin content is present as rare, small and big black globules or granules.

Rays - in cross section appear thin, linear and exclusively uniseriate in tangential section have sometimes some biseriate storeys, up to almost biseriate rays. The rays are of low type, having from 1-12 cells in height, sometimes more. Regarding the ray composition, the rays are homogeneous, with the parenchymal cells all procumbent, of 15-20 $\mu \mathrm{m}$ high, marginals taller, of up to 27-30 $\mu \mathrm{m}$. Ray tracheids - absent. The horizontal and the tangential endwalls of ray parenchyma cells are smooth and simply pitted. Indentures present, but often difficult to observe. In cross field, the pits are of cupressoid or taxodioid type or with glyptostroboid aspect, in one row arranged as 1-2 pits of 8-12 $\mu \mathrm{m}$, and more numerous, 3-5 (-6) pits, in the taller cross fields, when are in 2 superposed rows, or slightly irregularly arranged. Sometimes, globules of resin or granules are present inside the ray cells.

Resin canals - are absent.

Mineral inclusions - are not present.

\section{Affinities and discussions}

Glyptostroboxylon Conwentz emend. Dolezych \& van der Burgh, but closer to the current Cunninghamia R. Br., than to Glyptostrobus Endl. emend. Dolezych \& van der Burgh, 2004

In fact, as was showed above, long time ago, Kräusel (1913: 45, 46) had already observed such affinity and difference in specimens assigned to Glyptostroboxylon, and considered as separating the fossil wood of Cunninghamia-type from that of Glyptostrobus-type, especially based on the presence of cupressoid cross-fields rather than glyptostroboid ones. Eventually, he rejected the idea and the two distinct taxa have remained united as Glyptostroboxylon tenerum Conwentz (Kräusel 1913, 1919, 1949; Dolezych \& van der Burgh, 2004). It is known that the genus Glyptostrobus Endl. was described firstly in fossil (as Glyptostrobus tener by Kraus, 1864) and only later it was found as living tree in China and described by Henry \& McIntyre (1926) as Glyptostrobus pensilis (Staunton ex D. Don) K. Koch, known as "Chinese swamp cypress", and they considered it as a living fossil. Now, Glyptostroboxylon tenerum is interpreted as fossil wood of Cunninghamia type, because Gothan (1905) and later, Rudolph (1935), Watari (1948), Süss \& Velitzelos (1997) and Fairon-Demaret et al. (2003) have also observed structural affinities between the wood of Glyptostroboxylon tenerum and the one of the extant Cunninghamia $\mathrm{R} . \mathrm{Br}$.
Dolezych \& van der Burgh (2004), after a new investigation on the original material from Wetterau, the typelocality, decided that the affinity of this wood is not to Glyptostrobus Endl., but clearly to Cunninghamia R. Br., genus belonging now to the Subfamily Cunninghamioideae (Zucc. ex Endl.) Quinn, not to Taxodioideae Endl. ex K. Koch, so that it could be subject for a new revision even if it is admitted now as species of Glyptostroboxylon (Dolezych, 2011). We discuss below many other wood remains described as Glyptostroboxylon tenerum especially from Europe, and which are very similar to our studied material:

- Kräusel (1919) has determined from several Silesian sites, some xylites as Glyptostroboxylon tenerum and, for example, the specimen of Laasan has clear affinity to the recent Cunninghamia-wood, having in the crossfield three relatively large taxodioid and glyptostroboid pits, almost filling it ( Dolezych \& van der Burgh, 2004).

- $\quad$ Stockmans \& Willière (1934) have described a Glyptostroboxylon tenerum, from the Eocene from Belgium, with affinity to Cunninghamia-wood, having uniseriate radial pitting, loosely arranged.

- Schönfeld (1952) has described a Glyptostroboxylon tenerum, on an Eocene wood from Borna lignite mining area (Germany), also with a clear affinity to Cunninghamia, especially by the aspect of the cross-field pits.

- Kostyniuk (1967) has investigated some samples of xylite from the Cenozoic lignites of Turów (Poland), describing a Glyptostroboxylon tenerum, with glyptostroboid and taxodioid pits in cross field, which points to the affinity to Cunninghamia wood type.

- Greguss (1967) determined a silicified wood from late Miocene of Hungary as Glyptostroboxylon No. 2 , having uniseriate tracheidal pitting, suggesting affinity to Cunninghamia wood.

- Mathiesen (1970: 50-52) identified a wood from the lignite of Troldhede (Danemark), as Glyptostroboxylon tenerum, and even if he made a slightly confusing description, the illustrations clearly suggest the affinity to the current Cunnnghamia wood.

- Ravazzi \& van der Burgh (1995) described a Glyptostroboxylon tenerum, from the brown coal of Leffe palustrine deposits (Early Pleistocene, Lombardy, NItaly) as having the radial pitting of tracheids and cross field pitting which suggest clear affinity to the wood of Cunninghamia (Dolezych \& van der Burgh, 2004).

- The specimens described as Glyptostroboxylon tenerum, by Iamandei et al. (2001), from Eastern Carpathians and by Nagy et al. (2002) from South Apuseni mts. are probably wrongly identified, having glyptostroboid cross-field pits (see above).

- $\quad$ Fairon Demaret et al. (2003) have described an in situ Glyptostroboxylon tenerum, from the Eocene Forest of Hoegaarden (Belgium), the wood structure showing clear affinity to the wood type of Cunninghamia. 
- Süss \& Velitzelos (1997, 2008) have studied some wood remains of Glyptostroboxylon-type from Lesbos, describing a new species (Glyptostroboxylon microtracheidale Süss et Velitzelos), as having 'ovoid' pits in cross-fields (i.e. glyptostroboid pits), suggesting that it is probably a root wood and specifying that it $\mathrm{m}$ to be similar with that of Cunninghamia lanceolata (Lamb.) Hook., an extant Chinese species.

- Dolezych, M., (2011) identified some taxodiaceous woods in Lusatia (Central Europe), but also a Glyptostroboxylon tenerum with affinity to the wood-type of Cunninghamia. In fact, some years ago, Dolezych \& Van der Burgh (2004) have studied fossil wood from Wetterau, the locus tipicus for the original material of Kraus (1864), which proved similar to the current Cunninghamia (see above)

- And, also, Dolezych et al. (2018) studying some material from high latitudes of North America (Yukon, Elsemere Island and around), have described some Cretaceous-Paleogene conifers, among them a Glyptostroboxylon tenerum with its typical xylotomy.

Thus, taking into account the above disscussion for the first species of Gyptostroboxylon and the comparative discussion for this studied material, and based on the great similarity of the xylotomical characters of this studied rich material (53 specimens), with the details comprised in the specific diagnosis and with other identifications of fossil wood presented above and also, with the xylotomy of the current correspondent (Greguss, 1955), we attribute all the studied specimens to Glyptostroboxylon tenerum (Kraus) Conwentz, 1884. It is a perfect fossil equivalent of the actual Cunninghamia R.Br. (Dolezych, 2011), and is confirmed, also, by the presence of other fossil plant parts frequently described in the Aegean area as Cunninghamia miocenica Ettingshausen ( Velitzelos D. et al., 2014).

Order Pinales Gorozhankin, 1904

Family Pinaceae Lindley, 1836

Pinuxylon Gothan, 1905

Pinuxylon pineoides (Kraus) Koeniguer, 1967

Fig. 9, a-i.

\section{Material}

From all the studied samples of petrified wood collected from the Aegean area, some of them presented a pinaceous xylostructure, marked by the presence of axial resin canals of Pinus type. From them, 11 samples were grouped here as presenting a very similar xylotomy. They were collected from Lesbos Island - the samples numbered with Lsv334, 349, 365, 371, 380, 445, 451, 537, 558, 578 and from Limnos island - the sample Li.228. The studied material is registered as "Velitzelos Collection" and stored in the Collection of the Faculty of Geology and Geoenvironment, of the NKUA.

\section{Microscopic description}

Growth rings - are relatively wide, of 20-40 cells or more, show gradual transition or sometimes quite abrupt and distinct ring-boundaries in cross section. The earlywood is more or less developed, with relatively thinwalled tracheids, sometimes compressed and deformed, usually gradually diminishing in size up to the late-wood. Axial resin canals of pinoid type are present, with thinwalled epithelial cells sometimes destroyed, detailed described below.

Tracheids - have a polygonal cross section, with rounded corners and relatively thin walls in the early-wood, of 3-5 $\mu \mathrm{m}$ the double wall, and the radial / tangential diameter is of 25-45 / 15-35 $\mu \mathrm{m}$. The transitional wood is represented by thicker walled polygonal rounded tracheids, of 6-7 $\mu \mathrm{m}$ the double wall and with diameters of 15-25 / 10-15 $\mu \mathrm{m}$ ( $r / t g$ d.). The final wood which is represented by 6-8 rows of radially flattened thick-walled cells, having 8-10 $\mu \mathrm{m}$ the double wall, and smaller sized of 10-15/5-10 $\mu \mathrm{m}(\mathrm{r} / \mathrm{tg}$ d.). Between two succesive rays, 2-11 radial rows of tracheids can be counted. Also, intermingled between them, radial rows of tracheids with narrower-lumened tracheids can be $\mathrm{n}$, having smaller tangential diameter. Angular intercellular spaces between tracheids also appear. The density is $1150-1640$ tracheids per $\mathrm{mm}^{2}$. The tracheidal pitting appears usually poorly preserved. On the radial walls, abietineous pits of 16-20 $\mu \mathrm{m}$ in diameter appear, with round apertures of 5-7 $\mu \mathrm{m}$, predominantly uniseriate arranged, less biseriate, spaced or contiguous and without crassulae. Sometimes, on the tangential walls, small round to oval pits of (5-)8-12 $\mu \mathrm{m}$ in diameter appear, with small round aperture, spaced or contiguous and arranged in a single row. Organic deposits as resin inside the tracheids sometimes are present. Tracheid length could not be measured, due to poor preservation. The late-wood tracheid are thick walled. Helical thickenings absent, but sometimes inclined striations can be guessed.

Axial parenchyma - is absent.

Rays - appear in tangential view as uniseriate and multiseriate fusiform rays, with 1-2(3) resin canals sometimes with remains of epitelial cells. The uniseriate rays have of $2-15(-20)$ cells in height, so the average height is of medium type and have sometimes some biseriate storeys. The fusiform rays bear 1-2(3) resin canals, are of 2-3 cells wide and of 12-20 cells in height, having long uniseriate endings of 3-6 cells. Lateral intercellular triangular spaces are common. The ray-density is of 12-18 rays on tangential millimeter. In radial view the rays appear heterogeneous, with parenchymal ray-cells of 17-20 $\mu \mathrm{m}$ tall, and transversal ray-tracheids which appear either inside the ray-body or marginally arranged. Often, they are difficult to separate from the parenchymal body-cells, since 

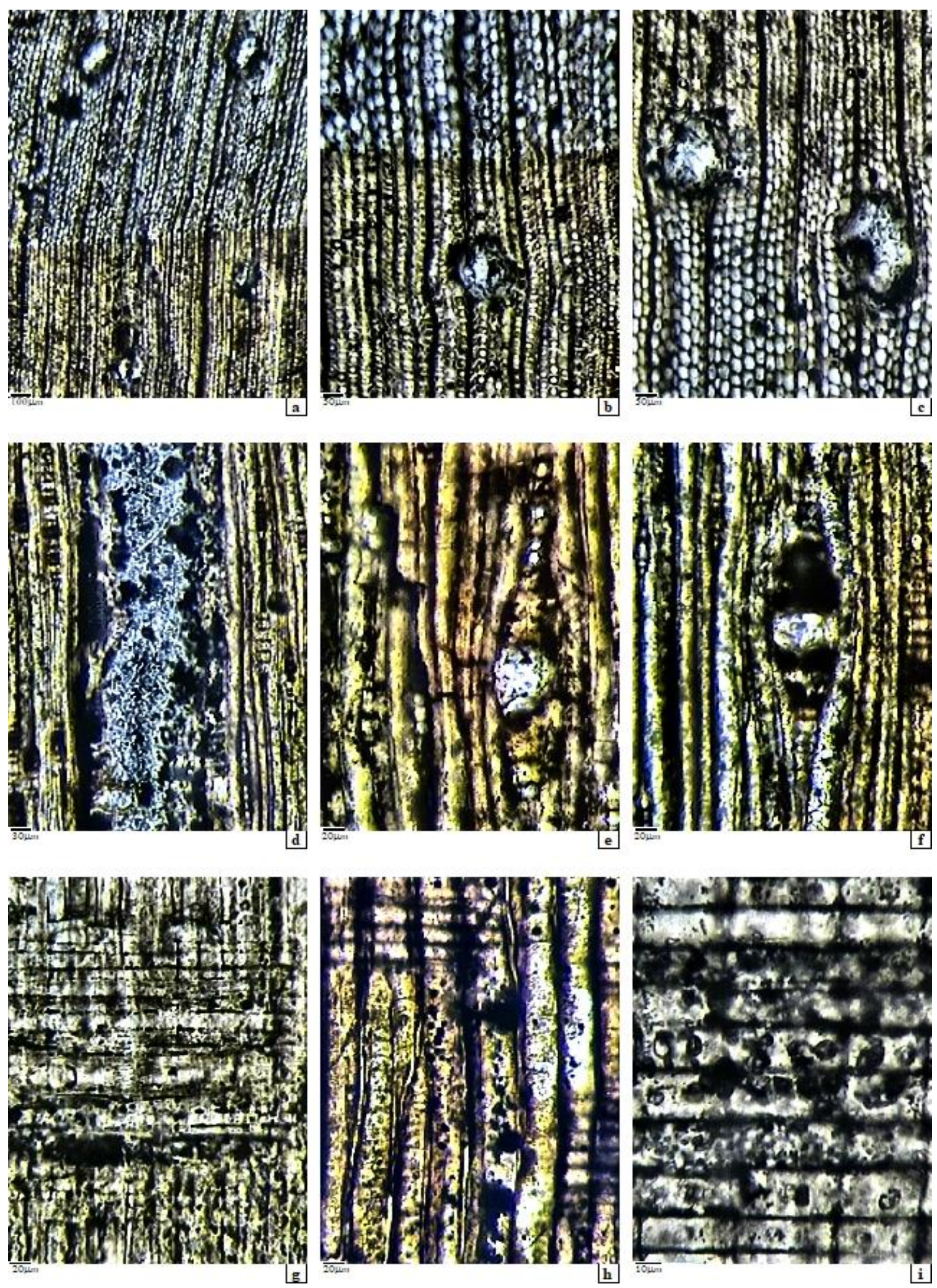

Fig. 9 a-i. (graphic scale). Pinuxylon pineoides (Kraus) Koeniguer, 1967; (Specimen Lsv.365).

a-c: Cross section - gradual transition, distinct growth rings; parenchyma absent; resin canals of pinoid type, with thin walledepithelial cells, partially destroyed; d-f: Tangential section - tracheids, uniseriate rays, axial canal (4), fusiform ray with ray-canal (5-6); g-i: Radial section - tracheidal pitting 1-2-seriate, opposite (8); rays homocellular, cells all procumbent, ray-tracheids weakly dentate; poorly preserved cross-field with 1-3(4) pinoid pits. 
they have smooth walls also, or slightly rough, maybe with some thickenings suggesting small denticles. The parenchymal ray-cell walls are smooth or slightly rough and unpitted, not too thick (2.5-3.5 $\mu \mathrm{m}$ double wall), while the tangential walls (or end-walls) are relatively thin, of 1.5-2 $\mu \mathrm{m}$ the simple wall, or slightly nodular, but usually poorly preserved. The ray-tracheids are slightly taller, up to $25-35 \mu \mathrm{m}$ or more, show wavy and rough outer wall, and are devoid of spiral thickenings. The normal cross fields show poorly preserved pitting as 1-2(-3) pinoid pits, often with taxodioid to cupresoid aspect of 8$10 \mu \mathrm{m}$ with large inclined lens-like apertures, arranged in a single row, or as 4-6 pits in two superposed rows or slightly irregular. The pits on the ray-tracheids are slightly smaller and more rounded that the normal ones, but usually poorly preserved. Indentures absent.

Radial resin canals - are present and appear intercellularly inside the ray-body, as 1-2(3) canals of 15-30 $\mu \mathrm{m}$ in diameter, often with resin grains inside and are lined by thin epitelial cells, most often destroyed.

Axial intercellular resin canals - are in circular or radially-oval shape, are surrounded by thin-walled epithelial parenchyma cells sometimes with small thickenings and are usually destroyed. The canals appear isolated or grouped in the growth ring, sometimes in the transitional wood, usually in the late wood but not close to the ring boundary. In cross section the canals are often narrow, having (30-) 100-150 (-200) $\mu \mathrm{m}$ tangential diameter. Traumatic canals are absent.

Mineral inclusions - are absent.

\section{Affinities and discussions}

In the first stage of the palaeoxylotomical study of a part of "Velitzelos Collection" there were selected the specimens showing coniferous structure with typical axial resin canals lined by thin-walled epithelial cells, that clearly indicate secondary wood of Pinus type. Even if often present poorly preserved, 11 specimens of them were grouped and studied here as having very similar xylotomy.

Thus, the studied petrified wood samples show a homoxylous structure in cross section, with typical normal axial resin canals not too large, lined by thin-walled epithelial cells usually destroyed, and appear isolated or grouped in the transitional wood and late-wood, but sometimes not only there, so defining a pinaceous secondary wood of Pinus type. This wood-type is different from other pinaceous genera, which have a very specific number of epithelial thick-walled cells lining the resin canals: Pseudotsuga has 5-7 cells, Picea has 8-10 cells and Larix has 10-14 cells, but they are thin-walled in $P i$ nus, and often destroyed (Greguss, 1955, p.121-123; Ickert-Bond, 2001).

Also, the presence of ray-tracheids having rough or slightly dentate walls is observed, an important taxonomic detail which leads to the pines of Diploxylon-type, the hard pines, classified under subgenus Pinus L. (Gernandt et al., 2005). This important detail distinguishes them from the pines of Haploxylon-type, the soft pines, classified under the subgenus Strobus Lemmon (Gernandt et al., 2005; Mantzouka et al., 2019a), which are characterized by smooth-walled ray-tracheids. The cross-fields show fenestriform or pinoid pits, which appear more or less numerous in both types of pines, so this detail could be of specific taxonomic value. Further details regarding the characteristics of the Pinus wood type derive from the papers of Bailey (1910), Phillips (1941), Jane (1956), Greguss (1955, 1962), Hudson (1960), Esau (1965), Patel (1971), van der Burgh (1973), Panshin \& De Zeeuw (1980), Süss (1989), Ickert-Bond (2001), Schoch et al. (2004), Farjon (2005b).

As a principle, we suppose that the extant European pines had mostly European Cenozoic ancestors and we enumerate here all the current European (many of them Mediterranean) pines of Diploxylon type (subgenus Pinus): Pinus halepensis, P. brutia, P. pinaster, P. pinea, P. canariensis, $P$. nigra, $P$. sylvestris, $P$. heildrichii, $P$. uncinata and of Haploxylon type (subgenus Strobus): Pinus peuce and P. cembra (Gernandt et al., 2005; Earle, 2020). In this context it was interesting to consult the paper of Barbero et al. (1998) who present the ecological status of the few current species of Pinus and their biogeography in the Mediterranean Basin.

As for the xylotomy of the European species, they have usually 1-2(3-6) pinoid (or piceoid) pits in cross fields, superposed or paired or in other arrangement, the radial traheidal pitting shows 1(-2)-seriate pits, and the parenchyma is usually absent or appear only exceptionally (Greguss, 1955, 1972; Dolezych et al., 2011).

The fossil genus Pinuxylon was defined by Gothan (1905), with Pinuxylon succiniferum Goeppert (Kräusel) as type-species which was emended later (Dolezych et al., 2011) after revising the original material of the bazionim Pinites succinifer Goeppert (in Goeppert \& Berendt, 1845), which was identified as a pine of Haploxylon-type. During the time, a large number of European species were referred to this fossil genus (Dolezych et al., 2011).

In order to identify the studied specimens, we have comparatively analyzed the European fossil pines described and published till now, specifying, when possible, their current equivalents, trying to find similarities with our studied material:

- $\quad$ Kräusel (1920) described Pinuxylon taedioides Kräusel and $P$. paxii Kräusel as pines of Diploxylon-type and, some years later, also Kräusel (1949) described a $P$. zobelianum (Göppert) Kräusel a fossil pine of Haploxylon-type, from cembra-group, giving also a synthesis of all the previous described forms, reported as fossil equivalents of the extant genus Pinus L., so, $\mathrm{m}$ to be different from our specimens. 
- $\quad$ Rössler (1937) described the species Pinuxylon cembraeforme Rössler, similar to extant Pinus cembra Strobus subsection (= of Haploxylon type); also, he described Pinuxylon vateri (Platen) Rössler which has similarities with the current Pinus taeda L., or with P. banksiana Lamb., and Pinuxylon paxii Kräusel - similar to Pinus pinaster Aiton, as pines of Dipoxylon-type, all from Germany ( also, by van der Burgh, 1973). All of them $\mathrm{m}$ to be different from our specimens.

- Some forms of Cenozoic fossil pines with taxodioid or round pits in cross fields, were described by Greguss $(1954,1967)$ as Pinuxylon haploxyloides Greguss, and also $P$. albicauloides Greguss, $P$. tarnocziense (Tuzson) Greguss and Pinuxylon sp., most probably all of them of Diploxylon type. The presence of spiral thickenings in $P$. albicauloides Greguss, described also by Roy \& Hills (1972), $\mathrm{m}$ to represent only shrinkage fissures due to diagenesis, as Dolezych \& Reinhardt (2020) observed. Anyway, there is no similarity with our specimens.

- Huard $(1966,1967)$ has described Pinuxylon arjuzanxianum Huard and $P$. landensis Huard both with pine wood of Diploxylon type and similar structure of pines from Pinaster subsection, but are different.

- Lecointre \& Koeniguer (1965) and Koeniguer (1967) described from Maroc a Pinuxylon pineoides (Kraus) Koeniguer, emmending a pine initially described by Kraus (1886), from Sicily, as species of Pityoxylon. This species has xylotomical details similar to the extant Pinus pinea L. and is also very similar to our here studied specimens, in regard to axial resin canals and cross field pitting.

- $\quad$ Some other pines characterized by small pinoid and even fenestriform pits in cross fields were identified only as Pinuxylon sp. by Petrescu \& Nuţu (1970) or by Comble et al. (1973); they are, probably, of Diploxylon type, but are not very similar to our studied specimens.Also, van der Burgh (1973) described two species also slightly different: Pinuxylon ponderosoides van der Burgh and $P$. halepensoides van der Burgh, both of Dipoxylon-type, similar to the current species of Pinaster subsection, based on the similarities of the aspect of the resin canals with their thin-walled epithelial cells. The last has a very similar wood structure with the current Pinus halepensis Miller (=Aleppo pine) in regard to the radial biseriate pits on tracheids and the ray-cells with nodular end-walls and pitted horizontal walls. Both species are different from our studied specimens.

- $\quad$ Privé-Gill \& Watelet (1980) described a Pinuxylon sp., quite similar to the $P$. parryoides (Gothan) Kräusel emend. van der Burgh, of Haploxylon-type, so it is different from our specimens.

- $\quad$ Iamandei \& Iamandei (2000) have described a species of pine of Haploxylon-type - Pinuxylon marinasii Iamandei et Iamandei - quite similar to $P$. parryoides (Gothan) Kräusel emend. van der Burgh, having large resin canals, radial uniseriate pitting on tracheids, sometimes irregularly paired or already biseriate, spaced or contiguous, and small taxodioid pits, therefore different from our specimens.

- By the study of some fossil wood remains collected from Miocene volcano-sedimentary sediments of Lemnos and Lesbos, Süss \& Velitzelos (1993, 1994, 2009) have described some species of Pinoxylon Knowlton emend. Read. But this is a Mesozoic genus of "protopinaceous" type, with internal wood structure of Pinustype, without fusiform rays with radial canals, as it is specified in the original diagnosis of Knowlton (1900, p.420). The genus Pinoxylon was considered by Medlyn \& Tidwell (1979) and by Stewart \& Rotwell (1993) as equivalent to Protopiceoxylon Gothan, so this taxonomic identifications of Süss \& Velitzelos remained problematic regarding the equivalence to an extant genus. Therfore, the authors preferred to create a new genus, Lesbosoxylon Süss et Velitzelos 2010, describing a new species and designating as type-species Lesbosoxylon ventricosuradiatum Süss et Velitzelos 2010, instead of Pinoxylon, described as having "idioblast-cells" in rays, and reattributing to this genus all the species described before, as follows: Lesbosoxylon parenchymatosum - with parenchyma; L. paradoxum - having spiral thickenings on tracheids; L. pseudoparadoxum - having very high rays; $L$. diversiradiatum - with 1-2-seriate rays; and L. graciliradiatum - having also "idioblast-cells" in rays ( Süss \& Velitzelos, 2010). Recently, a new species was described by Akkemik et al. (2020) as Lesbosoxylon kemaliyensis Akkemik \& Mantzouka, having a Pinus wood structure, with typical axial and radial resin canals, heterogeneous rays with smooth-walled ray-tracheids (Haploxylon type?), and pinoid cross fields. However, we consider the genus Lesbosoxylon Süss et Velitzelos as identical with Pinuxylon Gothan, so that a revision of the original material of all these species is still required. Anyway, all these species are different from our studied specimens.

- $\quad$ Petrescu \& Bican-Brişan (2004) described a Pinuxylon sp., studying a charcoalified material collected from the salt-mine of Ocna Dej (Romania). It has a pine structure, with resin canals, cross fields with 2-3 small pinoid pits in horizontal row, and ray tracheids which suggest Diploxylon-type of pine, slightly different of our material.

- $\quad$ Iamandei et al. $(2011,2016)$ also described Carpathian pines of Diploxylon type, characterized by large normal axial resin canals with moderately thick-walled epithelial cells, which was assigned to Pinuxylon sp. cf. Pinus sylvestris L., slightly different of our studied specimens.

- Dolezych et al. (2011) redescribing the original material on which Goeppert (1883) has described Pinites succinifer Goepp. (transfered by Gothan, 1906 - to Pinuxylon, as nov. comb.) and later confirmed by Kräusel as type-species for the genus Pinuxylon (Kräusel 1919, 
p.248-249; 1949, p.135), but without giving a diagnosis for it. Thus, after the original material of the bazionim was restudied, a diagnosis was offered by Dolezych (in Dolezych et al., 2011) for this type-species, correctly named Pinuxylon succiniferum (Goeppert) Kräusel emend. Dolezych, identified it as a pine of Haploxylon-type, combining features of pines from subgenus Strobus, with pinoid and ooporoid pits in cross fields, ray cell walls smooth or with thikenings and with thin-walled epithelial cells lining the axial resin canals. It is clearly different from our specimens.

- More recently Dolezych \& Reinhardt (2020) described Pinuxylon selmeierianum Dolezych \& Reinhardt from the Paleogene of northern Ellesmere Island, Canada, but anatomically similar to the current species Pinus lambertiana, an American pine of Haploxylon-type, also, different from our specimens.

- Mantzouka et al. (2019) described from Alonissos island, Greece, a new fossil species named Pinuxylon alonissianum Mantzouka et Sakala, of Diploxylon-type, considered as similar to some current species of Pinus especialy from Central America as Pinus arizonica Engelmann ex Rothrock, P. arizonica var. cooperi (C.E. Blanco) Farjon, P. engelmannii Carrière, P. jeffreyi Greville et Balfour, so, are different from our specimens.

- Recently, Akkemik et al. (2021) have identified also in the Anatolian area a Pinuxylon cf. P. tarnocziense (Tuzśon) Greguss, having subsidiary parenchyma cells around the resin canals, so, it is different of our specimens.

After this comparative analysis, we consider that the xylotomy of our studied specimens resembles well the structure of the current Pinus pinea L., as is described and figured by Greguss (1955), Schweingruber (1990), Akkemik \& Yaman (2012), and Crivellaro \& Schweingruber (2013). Pinus pinea L., known as the 'Stone pine', or 'Umbrella pine' is native to the Mediterranean region, occurring in Southern Europe, and Middle East (Earle, 2020). Xylotomically, the secondary wood of this pine has growth rings with gradual to abrupt transition from earlywood to latewood and axial resin canals of Pinus-type, with thin epithelial cells partially destroyed and usually located in the late wood. The tracheids have rectangular rounded cross-section in earlywood, smaller and radially flattened in latewood and, on the radial walls has uniseriate pits. The axial parenchyma is absent. The rays are uniseriate and low, of 1-8 cells, and fusiform, of 2-3 cells wide, and up to 15 cells tall, with 1-2(3) resin canals lined by thin-walled epithelial cells. The end walls of ray parenchyma cells are nodular, the horizontal walls pitted. Cross-fields with 1-2 cupressoid pits (as vertical pair) or more numerous, in 2-3 rows in the marginal cross-fields of ray-tracheids (heterogeneous rays). The ray tracheids have usually smooth walls or slightly rough, suggesting tiny denticles. The xylotomy of our studied specimens shows relatively wide growth rings, with gradual transition, sometimes quite abrupt, and distinct ring-boundaries. The normal resin canals are relatively narrow, and are located sometimes in the transitional wood, but usually in the late-wood, having thin walledepithelial cells, sometimes destroyed. The tracheids have polygonal-rounded cross section, not too large, with relatively thin-walls in the early wood, thicker in late-wood. The radial pits are predominantly in uniseriate arrangement, less biseriate, and without crassulae. Sometimes, tangential smaller pits appear. Parenchyma is absent. The rays, of medium height, are uniseriate and 2-3-seriate and fusiform, with long uniseriate endings and have 1-3 resin canals. The cells from the ray-body have the end-walls relatively thin or slightly nodular, and the ray-tracheids have smooth or rough wavy outer walls, rarely with some thickenings suggesting small denticles, and no spiral thickenings. Cross fields with 1-3 pinoid pits of 8-10 $\mu \mathrm{m}$ with cupressoid to taxodioid aspect, with inclined lenslike apertures, horizontally arranged, in a single row, or 4-6 pits in two superposed rows. Sometime, organic deposits appear inside of tracheids.

All these details, synthetically described for the studied specimens, suggest a pine of Diploxylon-type, classified under subgenus Pinus L. (Gernandt et al., 2005) and are similar to those described to the extant Pinus pinea L., as well as to those of the fossil species as it was described by Koeniguer (1967), so we decided to assign them, to the species Pinuxylon pineoides (Kraus) Koeniguer, 1967.

Pinuxylon halepensoides van der Burgh, 1973

Fig. 10, a-i.

\section{Material}

From the studied samples of petrified wood collected from Aegean area (insular part), 21 specimens showed a particular pinaceous xylostructure were selected. Those samples of silicified wood, were collected from early Miocene deposits from Lesbos: the samples Lsv.353, 354, 355, 356, 359, 362, 462, 539, 547, 550, 551, 555, 559, 560, 560a, 564, 569, 569a, 572, 579, and one from Limnos: Li.201. The studied material is registered as "Velitzelos Collection" and stored in the Collection of the Faculty of Geology and Geoenvironment, of the NKUA.

\section{Microscopic description}

Growth rings - relatively wide, often of more than 60 cells, showing quasi-gradual transition, but often abrupt or quite abrupt from the early wood to the late-wood, which has some rows of thick to very thick-walled tracheids, smaller and radially flattened, marking distinctly the ring boundaries. Normal axial resin canals of Pinus-type (described below) are present and appear isolated or in small groups usually in the late-wood. In some specimens (Lsv.353-356), the entire structures are invaded by large zoned crystals, and some dark remains, most 

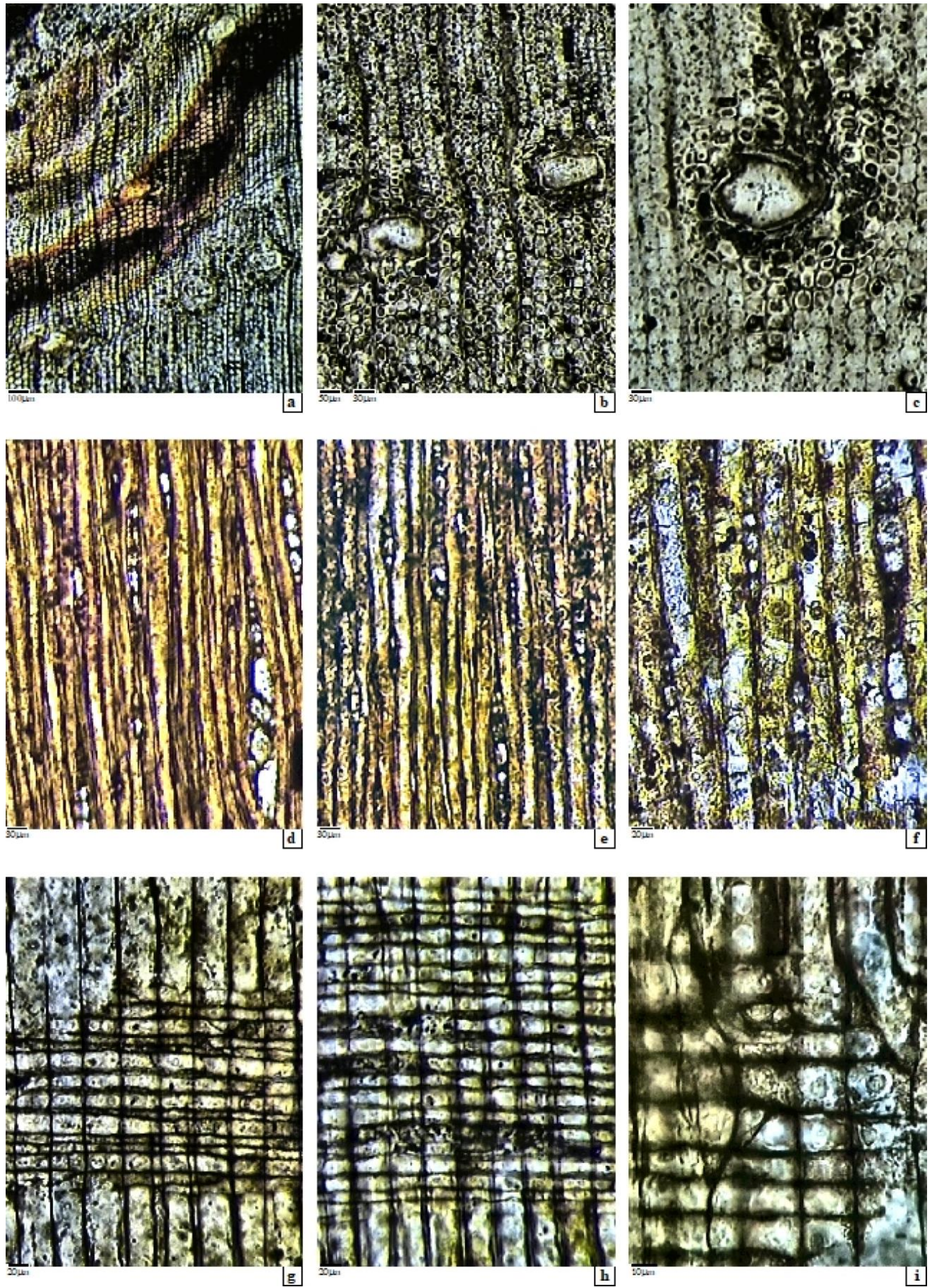

Fig. 10 a-i, (graphic scale). Pinuxylon halepensoides van der Burgh, 1973; (Specimen Lsv.569).

a-c: Cross section - gradual transition, very thick walled latewood, distinct growth rings; pinoid resin canals; d-f: Tangential section: tracheids, uniseriate rays with resin-canal (d,e); g-i: Radial section - tracheids with 1-2 seriate pits, opposite; ray-tracheids (i); badly preserved cross-fields with 1-3 pinoid pits. 
probably of secondary origin. Sometimes false growthrings are present, suggesting probably climatic variations. Also, sometimes the early-wood appears collapsed, due to compression.

Tracheids - have moderately thick walls in the earlywood (3-8 $\mu \mathrm{m}$ the double-wall) and appear polygonal with slightly rounded corners and with radial / tangential diameters of 25-45 / 17-35 $\mu \mathrm{m}$. In some specimens the cell walls are slightly corrugated. Toward the late-wood there is quite abrupt transition. The final late-wood comprises 6-13 rows of smaller and radially flattened tracheids of 8-18 / 5-15 $\mu \mathrm{m}$ in diameters and thick-walled, of $10-12 \mu \mathrm{m}$ the double wall. Between two rays, 2-11 radial rows of tracheids can be counted, rarely more. The density is of $1100-1600$ tracheids per $\mathrm{mm}^{2}$. Intercellular spaces throughout the wood structure are present. Often, in transversal view, radial rows of narrower tracheids can be $\mathrm{n}$ between the normal ones. The pitting on the radial walls appears of abietineous type, of 18-20(-22) $\mu \mathrm{m}$ in diameter and with round apertures of 4-7 $\mu \mathrm{m}$. The tracheidal pitting is usually poorly preserved, the pits are predominantly uniseriately arranged and appear spaced or contiguous, without crassulae. The pits are 1-2-seriately arranged, spaced or contiguous and without crassulae. No visible detail on the torus. On the tangential walls small, round to oval pits appear, of 8-12(15) $\mu \mathrm{m}$ in diameter, with small, round aperture, uniseriately arranged, spaced, and usually badly preserved. The length of the tracheids could not be measured, due to poor preservation. In longitudinal view, helical thickenings are absent but, sometimes, inclined striations were observed. Organic deposits as resin inside tracheids are often present.

Axial parenchyma - is absent.

Rays - are of two types: uniseriate rays, sometimes with some biseriate storeys, and fusiform rays 2-3(-4)-seriate, having 2-16(-20) cells in height, so they are of low to medium type. The fusiform rays are of 2-3 cells wide, have long uniseriate endings of 3-6 cells and bear 1-3 resin canals of $15-35 \mu \mathrm{m}$ in diameter, with thin epithelial cells, usually destroyed. Their height is of 12-20 cells. Resin canals may appear in the uniseriate rays also. Lateral, triangular intercellular spaces are common. The ray density is of 9-14 rays on tangential millimeter. In radial sections the rays appear heterogeneous, showing two kinds of cells, all procumbent. The parenchymal cells are of 15-20 $\mu \mathrm{m}$ tall have smooth walls or slightly rough and unpitted, not too thick (2.5-3.5 $\mu \mathrm{m}$ double wall), but the tangential end-walls have 1.5-2 $\mu \mathrm{m}$ (simple wall) and are slightly nodular. The ray-tracheids are slightly taller and appear either inside the ray-body, or more commonly, are marginally arranged and often they are difficult to differenciate from the parenchymal body-cells, having smooth walls and unpitted and not too thick (2.5-3.5 $\mu \mathrm{m}$ double wall). When marginal, the ray-tracheids are taller, of 25$35(-45) \mu \mathrm{m}$, and show slightly wavy outer wall, rough or with small thickenings to inside, suggesting tiny denti- cles. In the cross-fields, which are poorly preserved, can be guessed 1-3 pinoid pits of 8-10 $\mu \mathrm{m}$ (or with taxodioid aspect), horizontally arranged, having large, inclined, oval to lens-like apertures of 3-4.5 $\mu \mathrm{m}$. In the taller cross fields, there can be more pits, up to 6 , in 1-2 rows. On the ray tracheids the pits are rounded. Indentures are absent. Spiral thickenings are absent.

Radial resin canals - appear in the fusiform rays, but in the uniseriates also, as 1-3 narrow canals, among the raybody cells, having $15-35 \mu \mathrm{m}$ in diameter, and lined with thin epithelial cells, usually destroyed. Sometimes resin grains appear inside.

Axial resin canals - are present, with large, circular to oval cross section and appear isolated or in small groups, usually in the late-wood or close to it. The canals are relatively large-sized, of 75-250 $\mu \mathrm{m}$ the tangential diameter (150 $\mu \mathrm{m}$ mean diameter) and are lined by thin-walled epithelial cells which are often partially broken or destroyed. Traumatic canals absent.

Mineral inclusions - are usually absent but they were observed in some specimens (Lsv.353-356) as polygonal, large, zonated crystals, together with granular dark remains, irregularly arranged over all the structural elements. It ms that they formed secondary, during petrifying processes.

\section{Affinities and discussions}

From the studied material, 21 specimens with a similar pinaceous xylostructure and were grouped here by their particular features. So, they show in cross-section distinct growth rings, well developed, with thick-walled tracheids and axial canals lined by thin-walled epithelial cells, usually destroyed, which is typical for the secondary wood of Pinus-type (Greguss, 1955, p.121-123). Horizontal resin canals within fusiform rays are also present, and the rays are heterogeneous, with taller ray-tracheids with tiny denticles, detail which suggest a pine of Diploxylon-type, i.e. from subgenus Pinus L. (Ickert-Bond, 2001, p. 361). In some specimens (Lsv.353-356), the sections reveal large, zonated crystals or granular dark remains, most probably of secondary origin since the entire structure is invaded.

- Based on the supposition that the studied fossil pines are the ancestors of the current subtropical or Mediterranean pines, we tried a comparison with the current Pinus halepensis Miller, commonly known as the Aleppo pine (Earle, 2018), as xylotomically described by Esteban et al. (2010) since we observed some similarities to our specimens, like the quite thick-walled tracheids, even in the early-wood, with uniseriate radial and tangential pitting, with no crassulae. Also, the parenchyma is absent and in the uniseriate and fusiform rays appear 1-3 resin canals, cross-fields have 1-3(-6) piceoid to pinoid small pits and ray-tracheids have tiny denticles.

- All these details are present also in the species Pinuxylon halepensoides, an equivalent fossil species was described by van der Burgh (1973) and which have also 
been identified and described by Dolezych (2005) and Dolezych \& Schneider (2006) as having "not too thick walled tracheids, with radial pitting usually uniseriate, with pits relatively small, with no crassulae and with pitted tangential walls; parenchyma sparse or absent; rays uniseriate and low, the multiseriates having resin canals and ray-height of 10-12 cells. The walls of the ray-cells are thick and pitted. In cross fields there are usually one, rarely two piceoid to pinoid small pits of $6 \mu \mathrm{m}$. The raytracheids appear mostly marginal, and have serrations of medium size in their walls suggesting small denticles. Resin canals of Pinus type, with thin-walled epithelial cells are present" ( Dolezych \& Schneider, 2006).

- Esteban et al. (2010), studying the current species Pinus halepensis, remark a great similarity with $P i$ nus brutia Tenore, another Mediterranean species with xylostructure close to our studied specimens, having, for example, the axial resin canals located only in the latewood. In fact, both Pinus halepensis and P. brutia have very similar woods and separating them with wood natomical features are almost impossible (Schweingruber, 1988; Akkemik and Yaman, 2012). For that reason, both two species may be evaluated in their fossil forms, as Pinuxylon halepensoides.

- In fact, long before them, Greguss (1955, p. 231) described Pinus halepensis and P. brutia, specifying that "there is no difference in the walls of early and late tracheids", refering to their thickness, and "teeth barely emerge from the walls of transverse tracheids", detail similar to our studied specimens. Also, Greguss (1972, p.127) has described Pinus brutia var. eldarica Medv. as having beside the typical features of the species, "thick walled to very thick-walled tracheids from early- to late wood", which is quite similar to our studied specimens. Anyway, this difference is not clear even in modern woods (Akkemik, 2021, pers. communication).

- Moreover, the short descriptions and figuration presented in Schweigruber (1990), Akkemik \& Yaman (2012) and Crivellaro \& Schweingruber (2013) for Pinus brutia are very similar to our studied material.

Our specimens present very similar xylotomy to the original description of Pinuxylon halepensoides and, also, to the description of the curren species Pinus halepensis as presented above after Esteban et al. (2010), compiled with those of other authors cited above, having axial canals isolated or in small groups, usually in the transitional and late wood and sometimes, close to ring boundary, heterogeneous rays with canals, crystals. Based on this discussion on the affinities of the xylotomy of the studied specimens, we decided to attribute all of them to the fossil species Pinuxylon halepensoides Van der Burgh, 1973.

Pinuxylon sp. aff. Pinus canariensis C. Sm. Fig. 11, a-i.

\section{Material}

Some samples of petrified wood showing similar pinaceous xylostructure, were grouped as having parenchyma of a special type. These four samples with field numbers Lsv.4, 357, 389, 543 represent fragments of petrified (silicified) wood and were collected from Lesbos Island. The studied material is registered as "Velitzelos Collection" and stored in the Collection of the Faculty of Geology and Geoenvironment, of the NKUA.

\section{Microscopic description}

Growth rings - are well developed, wide of more than 60 cells, with gradual transition from early- to late-wood, sometimes quite abrupt and with distinct growth-ring boundaries, in cross-section. Normal axial resin canals of Pinus-type are present, with thin-walled epithelial cells often destroyed and accompanied, sometimes, by some axial parenchyma as subsidiary tissue, details described below. The wood structure is quite compressed in the early wood, or is locally collapsed.

Tracheids - are relatively thin-walled in the early-wood, showing a quasi-polygonal cross section, large and often deformed by compression and show slightly corrugated walls. They have radial / tangential diameters of (25)40$60 /$ (20)35-50 $\mu \mathrm{m}$, and wall thickness of 4-6 $\mu \mathrm{m}$ (double wall), in the early wood. When transition is gradual a well-developed transitional wood is visible, with tracheids relatively thicker-walled (of 6-8 $\mu \mathrm{m}$ the double wall), and their cross-section is of 10-20/20-30 $\mu \mathrm{m}$ in diameters (ra/tg), gradually diminishing to the final rows of late-wood where they appear as radially flattened cells, thick-walled (8-10 $\mu \mathrm{m}$ the double wall), marking the growth-ring boundary. Between two successive rays 1-9(15) radial rows of tracheids were counted. Sometimes radial rows of smaller tracheids are intermingled. The tracheid density is around 1500 tracheids per $\mathrm{mm}^{2}$. In longitudinal view, the tracheids present $1(-2)$-seriate pitting on the radial walls, more or less contiguous, sometimes with crassulae. The pits are of abietineous type, are 17-24 $\mu \mathrm{m}$ in diameter and round apertures of 4-5 $\mu \mathrm{m}$. Because of poor preservation, no visible details on torus were $\mathrm{n}$. On the tangential walls, a few, uniseriate, small round pits of 5-8 $\mu \mathrm{m}$ in diameter and with small round aperture were observed. Organic deposits inside the tracheids are often present as resinous plugs or sometimes irregular dark patches covering other structural elements also. Tracheids' length could not be measured. Intercellular spaces often present. Late-wood tracheids - thick walled. Helical thickenings on tracheids absent.

Axial parenchyma - is exceptionally present, either as some parenchyma cells more or less accompanying the axial canals as a subsidiary parenchyma either aliform, or as diffuse small insular groups of moderately thickwalled cells, with some granular content of resin or starch. In longitudinal view they appear as groups of rectangular cells. 

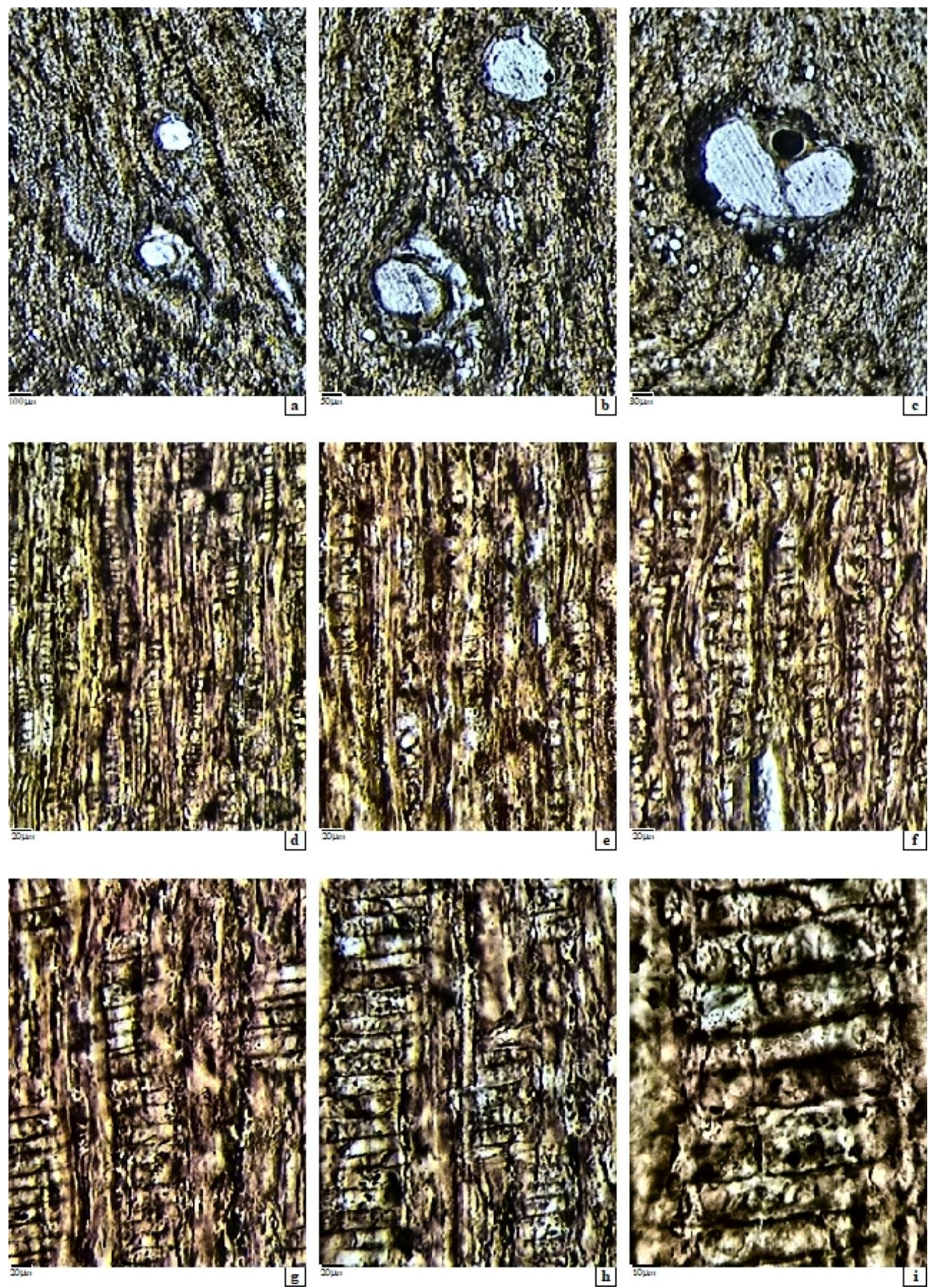

Fig. 11 a-i, (graphic scale). Pinuxylon sp. aff. Pinus canariensis C. Sm.; (Specimen Lsv.389).

a-c: Cross-section - resin canals of pinoid type, with thin-walled epithelial cells and subsidiary tissue (arrow); d-f: Tangential section - tracheids, parenchyma (arrow), rays uniseriate and fusiform; g-i: Radial section - tracheidal pitting 1-2-seriate; rays cells all procumbent, ray-tracheids weakly dentate; cross-field with 1-3(4) pinoid pits (arrow). 
Rays - are of two kinds: uniseriate and multiseriate. The uniseriates have sometimes some biseriate storeys and can have up to 16 cells high or more, the average height is of about $180 \mu \mathrm{m}$. The fusiform rays are 2-3 seriate with uniseriate endings of 3-6 cells, having 15-20 cells in height and can include 1-3 resin canals. Lateral triangular intercellular spaces are common. Ray density is of 17-18 rays per tangential millimeter. In radial view the heterogeneous character can be observed. Thus, beside the parenchymal body-cells have $10-15(-18) \mu \mathrm{m}$ in height, ray-tracheids appear, either inside the ray-body or marginally arranged and sometimes difficult to differentiate them from the other ray-cells, since they resemble. The horizontal walls of the parenchymal cells are smooth or slightly rough and probably pitted and are relatively thinwalled (2-3.5 $\mu \mathrm{m}$ double wall), while the tangential walls (the end-walls) are thin, of 1.5-2 $\mu \mathrm{m}$ the simple wall and smooth or slightly nodular. The indentures are missing. The ray-tracheids are slightly taller, of $25 \mu \mathrm{m}$ or more, and show harsh horizontal walls, sometimes with small thickenings suggesting tiny denticles and, when marginally arranged, have the outer wall slightly wavy. Helical thickenings were not observed. In cross fields the pitting appears as 1-3(4) pits or more in 1-2 rows horizontally arranged. They are small inclined pinoid pits, or piceoid to taxodioid, of 9-11 / 5-8 $\mu \mathrm{m}$ in diameters, with lens-like apertures, of 3-4.5 $\mu \mathrm{m}$. On the ray-tracheids they are slightly rounded. Often the cross-field pitting is difficult to observe due to bad preservation or to presence of organic content.

Radial resin canals - appear as 1-2(3) inside the raybody, are narrower, of 10-17(25) $\mu \mathrm{m}$ in diameter (average diameter 14-15 $\mu \mathrm{m}$ ). Resin grains can be observed inside them. The epithelial cells are usually destroyed, or less visible.

Axial resin canals - are of Pinus-type and have circular or slightly oval shape in cross section. They appear usually isolated or in small groups in the growth ring, often in the early wood, but also in transitional toward the late wood. The canals are quite large, of 150-200-350 / 120$250 \mu \mathrm{m}$ the radial / tangential diameter, sometimes with resin-remains inside and are lined by the thin-walled epithelial cells sometimes with starch grains inside, often destroyed. The canals are accompanied by subsidiary tissue, sometimesc with aliform aspect. Traumatic canals are absent.

Mineral inclusions - absent but sometimes starch grains appear, inside radial or axial parenchyma.

\section{Affinities and discussions}

Four samples of petrified wood collected from Lesbos Island, all sharing a special pinaceous wood structure which, even if poorly preserved, is characterized by the presence of axial resin canals of Pinus-type, lined by thin epithelial cells. These axial canals are often accompanied by groups of parenchymal cells, most probably representing a subsidiary tissue, similar to that described by 98
Esteban et al. (2005) for the xylostructure of Pinus canariensis C. Sm., an evergreen subtropical pine, endemic now in Canary Islands were grows at 1500-2000 m altitude (Earle, 2018). In radial section, our specimens present heterogeneous rays with taller ray-tracheids and with rough horizontal walls or even slightly dentate, detail which confirms that it is a pine of Diploxylon-type, from subgenus Pinus L., (Ickert-Bond, 2001 and Gernandt et al., 2005).

- Greguss (1955, p.232) made a short description of the xylotomy of Pinus canariensis C.Sm., noting that this pine native to the Canary Islands and has a great xylotomical similarity to Pinus halepensis Mill.

- However, Esteban et al. (2005) doing a very detailed xylotomical study of Pinus canariensis, have described a lot of microscopical details that are very specific and useful in wood identification of this pine, as follows: "Growth rings distinct, with relatively gradual change. Axial resin canals with thin epithelial cells bearing starch grains and located in the transitional-wood or in the late-wood, rarely in the early-wood and having mean tangential diameter of $221 \mu \mathrm{m}$. Tracheids with irregular to hexagonal or square cross-section, of 40-50 $\mu \mathrm{m}$ and with intercellular spaces. Large radial pits, of $24 \mu \mathrm{m}$, 1(-2)-seriate and with crassulae. Tangential pits not observed. Parenchyma as subsidiary tissue appear, close to axial canals, in aliform to confluent or diffuse groups, bearing starch grains. Rays uniseriate of 2-32 cells high, and fusiform multiseriate rays with resin canals, heterogeneous and homocellular. The thick-walled rayparenchyma cells with horizontal walls pitted and endwalls smooth, with high content of starch grains and cross field pits of pinoid type, 1-2(-4) per field. The raytracheids appear marginally or in ray-body, with irregular thickenings sometimes as small dentations and smaller pits".

- As already suggested by the presence of subsidiary tissue, sometimes of aliform type, also observed in our studied specimens, most likely we talk about a fossil pine with many xylotomical affinities with Pinus canariensis, as described by Esteban et al. (2005). Microscopic observation revealed other similar details, but the presence of the typical subsidiary tissue definitely indicates affinity of our studied specimens to the above specified pine.

- Recently a new Miocene fossil pine species, from eastern Turkey, was described as Lesbosoxylon kemaliyense Akkemik \& Mantzouka (in Akkemik et al., 2020a). The specific diagnostic features of the new species are: transition from earlywood to latewood mostly gradual; axial and radial resin canals with thin-walled epithelial cells; latewood tracheids thin to thick walled; bordered pits on radial walls of tracheids 1-2(-3) seriate; crassulae common; rays uniseriate, partly biseriate; uniseriate rays up to 27 cells high; fusiform rays up to 30 cells high; axial parenchyma occasionally present; ray trache- 
ids 2-3 rows; cell walls of ray tracheids smooth; cross field pitting pinoid, 1-2(-6) pits per cross field. Anyway, after detailed investigation of the botanical affinities of the new fossil wood, it is suggested that the most closely related modern species is Pinus canariensis. This "living fossil" could be close to our described specimens, but it is slightly different by having higher rays and no typical subsidiary tissue, even if is noted in description: "axial parenchyma is occasionally present".

- In another recent study, Akkemik et al. (2021) described from Turkey a mid Eocene pine with parenchymal cells around the resin canals interpreted as subsidiary tissue and identified as Pinuxylon cf. P. tarnocziense (Tuzśon) Greguss and could be similar to our specimens.

Therefore, taking into account the above discussion on the xylotomical similarity of the studied material with the structure of the current Pinus canariensis, (in Esteban et al., 2005), with weakly dentate ray-tracheids, large axial resin-canals of Pinus type with thin-walled epithelial cells, and accompanied by aliform subsidiary tissue, we assign our studied specimens to Pinuxylon sp. aff. Pinus canariensis C. Sm. since we had few specimens in study, rather poorly preserved, with not enough xylotomical details to identify a known species or to describe a new one.

\section{DISCUSSION AND CONCLUSION}

This paper is a new part of the xylotomic study of "Velitzelos Collection" of petrified wood from Aegean area, Greece, which is a public collection registered and kept in the "Collections of the Faculty of Geology and Geoenvironment", of the National and Kapodistrian University of Athens. In this study, fossil conifer remains were selected and studied representing 200 samples collected from continental part (Evros area), as well as from island part of Greece (Lesbos, Limnos), from late Oligocene and early Miocene deposits. From those samples, 10 species were identified, sometimes only at generic level and with possible affinity for some current species, and this due to poor preservation state of the structural details. The identified taxa are listed below:

1. Cupressinoxylon akdiki Özgüven-Ertan, 1977 - as fossil equivalent of the extant Cupressus L.

2. Juniperoxylon acarcae Akkemik, 2020 - as fossil equivalent of Mediterranean Juniperus L.

3. Tetraclinoxylon velitzelosii Süss, 1997 - as fossil equivalent of Tetraclinis Mast.

4. Taxodioxylon gypsaceum (Goepp.) Kräusel, 1949 - as fossil equivalent of Sequoia Endl.

5. Taxodioxylon taxodii Gothan, 1906 - as fossil equivalent of Taxodium Rich.

6. Glyptostroboxylon rudolphii Dolezych \& van der Burgh, 2004 - as fossil equivalent of Glyptostrobus Endl.
7. Glyptostroboxylon tenerum (Kraus) Conwentz, 1884 - as fossil equivalent of Cunninghamia R.Br.

8. Pinuxylon pineoides (Kraus) Koeniguer, 1967 - as fossil equivalent of Pinus pinea $\mathrm{L}$.

9. Pinuxylon halepensoides Van der Burgh, 1973 - as fossil equivalent of Pinus halepensis Mill. and P. brutia Ten.

10. Pinuxylon sp. aff. Pinus canariensis C. Sm. - with the specified affinity.

As a principle, we have considered that the Cenozoic fossil tree taxa should be the ancestors of the current species living in the same area, but some of them may be extinct, at least from the studied area. Anyway, the numerous fossil plant remains from Greek territory preserved in different ways suggest that during the Cenozoic time these regions evolved as highly forested lands, and the fossil plant associations already described so far strongly support this theory. The synthesis of Velitzelos et al. (2014) suggest a succession of mixed mesophytic forests that lived in a subtropical palaeoclimate to warmtemperate, strongly influenced by the neighboring of the sea, within the Aegean area. As it was shortly presented in the introductive chapter of the first part of this study (Velitzelos et al., 2019), and more detailed in Velitzelos et al. (2014), all the emerged regions were covered by extended forests of conifers, of arboreal dicotyledons as Laurales, Fabales, Myrtales and monocotyledons, especially Arecales, as we have described and discussed in the first part of our study (Velitzelos et al., 2019).

\section{ACKNOWLEDGEMENTS}

This paper represents the scientific result of the cooperation, as invited rearchers, in the projects of Professor Evangelos Velitzelos, developed some years ago at the Faculty of Geology and Geoenvironment, of the National and Kapodistrian University of Athens.

The authors thank a lot to the anonymous reviewers and to the editors, for their constructive comments, that helped us improve the manuscript.

\section{REFERENCES}

Acarca-Bayam, N.N., Akkemik, Ü., Poole, I. \& Ferdi, A., 2018. Further contributions to the early Miocene forest vegetation of the Galatian Volcanic Province, Turkey. Palaeobotanica Electronica, 21.3.40A: 1-42. palaeo-electronica.org/content/2018/2353-trees-ofgvp-in-miocene

Afonin, M.A., 2013. Fossil wood Sequoioxylon dimyense sp. nov. (Cupressaceae) from the upper cretaceous of Zeya-Bureya basin, Russian Far East. Paleontology Journal, 47: 631-640. https://doi.org/10.1134/S0031030113060026 
Akkemik, Ü., 2019a. New fossil wood descriptions from the Pliocene of central Anatolia and the presence of Taxodioxylon in Turkey from the Oligocene to Pliocene. Turkish Journal of Earth Sciences, 28: 398-409. doi:10.3906/yer-1805-24

Akkemik, Ü., 2019b. Jeolojik Çağlardan Günümüze Çamların Anadolu'daki Varlığı. Yeşil Dünya Akademi, Orman mühendisleri odasi yayin organi Geleceğimiz için: 26-35 (= The presence of pines in Anatolia from geological ages to today). Green World Academy, Chamber of forest engineers broadcasting organ - for our future: 26-35); [In Turkish].

Akkemik, Ü., 2020a. A new species of Juniperoxylon from the early Miocene of northwestern Turkey. Acta Palaeontologica Romaniae, 17(1): 15-26. Akkemik_Juniperoxylon_2.pdf （geopaleontologica.org)

Akkemik, Ü., 2020b. Some fossil conifer species descriptions from the Paleogene to Pliocene of Turkey and their evaluations. Eurasian Journal of Forest Science, 8(3): 244-257. http://dergipark.gov.tr/ejejfs

Akkemik, Ü., Köse, N. \& Poole, I., 2005. Sequoioiodae (Cupressaceae) woods from the upper Oligocene of European Turkey (Thrace). Phytologia Balcanica, 11(2): 119-131.

Akkemik, Ü., Türkoğlu, N., Poole, I., Çiçek, I., Köse, N. \& Gürgen, G., 2009. Woods of a Miocene Petrified Forest near Ankara, Turkey. Turkish Journal of Agriculture and Forestry, 33: 89-97.

Akkemik, Ü. \& Yaman, B., 2012. Wood Anatomy of Eastern Mediterranean Species. Publisher: Kessel Publishing House, Germany. ISBN: 978-3-94130059-0 www.forestrybooks.com; www.forstbuch.de; www.VerlagKessel.de

Akkemik, Ü., Sakinç, M., 2013. Sequoioxylon petrified woods from the Mid to Late Oligocene of Thrace (Turkey). IAWA Journal, 34 (2): 177-182. https://doi.org/10.1163/22941932-00000015

Akkemik, Ü., Arslan, M., Poole, I., Tosun, S., Köse, N., Karlioğlu, K.N. \& Aydin A., 2016. Silicified woods from two previously undescribed early Miocene forest sites near Seben, northwest Turkey. Review of Palaeobotany and Palynology, 235: 31-50. https://doi.org/10.1016/j.revpalbo.2016.09.012

Akkemik, Ü., Acarca, N.N. \& Hatipoğlu, M., 2017. The first Glyptostroboxylon from the Miocene of Turkey. IAWA Journal, 38(4): 561-570. https://doi.org/10.1163/22941932-20170181

Akkemik, Ü., Atici, G., Poole, I. \& Çobankaya, M., 2018. Three new silicified woods from a newly discovered earliest Miocene forest site in the Haymana Basin (Ankara, Turkey). Review of Palaeobotany and Palynology, 254: 49-64.

Akkemik, Ü., Yildirim, D.K., Sakala, J., Akkiliç, H. \& Altinişik, A., 2019a. New petrified wood descriptions from west-central Anatolia: contribution to the composition of the Neogene forest of Turkey. Neues Jahr- buch für Geologie und Paläontologie, Abh., 292(1): 57-71. https://doi.org/10.1127/njgpa/2019/0808

Akkemik, Ü. \& Acarca Bayam, N.N., 2019b. The first Glyptostroboxylon and Taxodioxylon descriptions from the late Miocene of Turkey. Fossil Imprint, 75(2): 268-280, Praha. ISSN 2533-4050 (print), ISSN 2533-4069 (on-line).

Akkemik, Ü, Akkiliç, H. \& Güngör, Y., 2019c. Fossil wood from the Neogene of the Kilyos coastal area in Istanbul, Turkey. Palaeontographica, Abt. B: Palaeobotany - Palaeophytology, 299(1-6): 133-185. Stuttgart.

Akkemik, Ü., Mantzouka, D. \& Yildirim, D.K., 2020a. The first report of Lesbosoxylon Süss \& Velitzelos from the early-middle Miocene of eastern Anatolia. Geodiversitas, $\quad$ 42(23): $427-441$. https://doi.org/10.5252/geodiversitas2020v42a23. http://geodiversitas.com/42/23

Akkemik, Ü., Mantzouka, D., Tunç, U. \& Koçbulut, F., 2021. The first Palaeoxylotomical evidence from the Mid-Eocene Climate Optimum from Turkey. Review of Palaeobotany and Palynology, 285; ISSN 00346667, https://doi.org/10.1016/j.revpalbo.2020.104356

Andrews, H.N., 1936. A new Sequoioxylon from Florissant, Colorado. Annals of the Missouri Botanical Garden, 23: 439-447.

Asensi-Amorós V., 2016. "The history of conifers in Egypt, part I: Mediterranean cypress (Cupressus sempervirens L., Cupressaceae)". In "News from the past: Progress in African archaeobotany" - [Proceedings of the $7^{\text {th }}$ International Workshop on African Archaeobotany in Vienna, 2-5 July 2012. U. Thanheiser (ed.), Groningen: Barkhuis, coll. Advances in Archaeobotany], 3: 3-11.

APG III. 2009. An update of the Angiosperm Phylogeny Group classification for the orders and families of flowering plants: APG III. Botanical Journal of the Linnean Society, 161(2): 105-121. DOI: 10.1111/j.1095-8339.2009.00996.x

APG IV. 2016. An update of the Angiosperm Phylogeny Group classification for the orders and families of flowering plants: APG IV. Botanical Journal of the Linnean Society, 181(1): 1-2. DOI: 10.1111/boj. 12385

Bailey, I.W., 1910. Anatomical Characters in the Evolution of Pinus. The American Naturalist, 44(521): 284293. Published for The American Society of Naturalists; https://doi.org/10.1086/279139

Bamford, M., Zijlstra, G. \& Philippe, M., 2002. Proposal to conserve the name Cupressinoxylon Göppert (fossil Gymnospermae, Coniferales) against Retinodendron Zenker. (Fossil, Gymnospermae, Coniferales), with a conserved type. Taxon 51: 205-206.

Barale, G., 1987. Les Cheirolépidiacées du Jurassique inférieur de Saint-Fromond, bassin de Carentan (Manche-France). Bulletin de la Société Botanique de France 134: 19-37. Crossref 
Barbéro, M., Loisel, R., Quézel, P., Richardson, D.M. \& Romane, F., 1998. Pines of the Mediterranean Basin. In: Richardson, D.M. (ed): Ecology and biogeography of Pinus. Cambridge University Press, Cambridge, pp $153-170$.

Beck, G.F., 1945. Tertiary coniferous woods of western North America. Northwest science, 9(4): 94

Berendt, G.K. \& Göppert, H., 1845: Die im Bernstein befindlichen organischen Reste der Vorwelt. Erster Band. I. Abtheilung. Der Bernstein und die in ihm befindlichen Pflanzenreste der Vorwelt. Nicolai, Berlin 1845

Berger, W., 1953. Jungtertiäre Pflanzenreste aus dem Gebiet der Ägais (Lemnos, Thessaloniki). Annales Géologiques des Pays Helléniques, 15: 34-54.

Biondi, E., 1979. Tetraclinoxylon anglonae: nova specie di legno fossile della Sardegna del nord. Boll. Soc. Sarda Sci. Nat., 19: 203-215

Biondi, E. \& Brugiapaglia, E., 1991. Taxodioxylon gypsaceum in the fossil forest of Dunarobba (Umbria, Central Italy). Flora Mediterranea, 1: 111-120.

Biondi, E. \& Brugiapaglia, E., 2000. I legni della foresta fossile di Dunarobba. La Foresta Fossile di Dunarobba. Atti del Convegno Internazionale, Ediart, Todi, pp. 65-71.

Blakey, R., 2020. DeepTimeMaps ${ }^{\mathrm{TM}}$ - oline at https://deeptimemaps.com/europe-series-thumbnails/

Blokhina, N. I., 1986. Sequoia Wood from the Late Oligocene of Siziman Bay, Khabarovsk Krai. Paleontologicheskii Zhurnal, 3: 131-135.

Blokhina, N. I., 1997. Fossil Wood of Sequoioxylon chemrylicum sp. nov. (Taxodiaceae) from the Paleogene of Chemurnaut Bay, Kamchatka. Paleontological Journal, 31(2): 235-238.

Blokhina, N. I., 2004. Fossil Wood Sequoioxylon sachalinicum sp. nov. (Taxodiaceae) from the Tertiary Deposits of Western Sakhalin Island. Botanicheskii Zhurnal, 89(5): 139-147.

Blokhina, N.I. \& Nassichuk, W.W., 2000. Lower Tertiary Wood of Sequoioxylon canadense sp. nov. (Taxodiaceae) from a Kimberlite Pipe (Northern Canada). Botanicheskii Zhurnal, 85(4): 122-132.

Blokhina, N.I., Afonin, M.A. \& Kodrul, T.M., 2010. Fossil wood of Sequoioxylon burejense sp. nov. (Taxodiaceae) from the Upper Cretaceous of the Zeya-Bureya Basin (Russian Far East). Paleontological Journal, 44, 1231-1239 (2010).

Bodnar, J., Ruiz, D.P., Artabe, A.E., Morel, E.M. \& Ganuza, D., 2015. Voltziales y Pinales (= Coniferales) de la Formación Cortaderita (Triásico Medio), Argentina, y su implicancia en la reconstrucción de las coníferas triásicas. Revista Brasileira de Paleontologia, 18: 141-160. Crossref

Březinová, D., Holý, F., Kužvartová, A. \& Kvaček, Z., 1994. A silicified stem of Podocarpoxylon helmstedtianum Gottwald, 1966. From the Paleogene site
Kučlín (NW Bohemia). Journal of the Czech Geological Society, 39: 221-234

Buchholz, J.T., 1939. The generic segregation of the Sequoias. Amer. J. Bot., 26: 535-538.

Burnett, G.T., 1835. Outlines of Botany (p. 816, 1094, 1118) Henry Renshaw, London (fide James L. Reveal, Index Nominum Supragenicorum Plantarum Vascularium)

Charrier, G. 1961., Nuova segnalazione di un orizzonte lacustre a legni di conifera presso Nuraghe Mamucone (Urzulei) alla basa dela serie transgressiva giurese del Golfo di Orosei (Sardegna centroorientale) studio stratigrafico e paleoxilologico. Bollettino della Società Geologica Italiana 80: 207-225.

Christenhusz, M.J.M., Reveal, J.L., Farjon, A., Gardner, M.F., Mill, R.R., \& Chase, M.W., 2011. A new classification and linear sequence of extant gymnosperms. Phytotaxa, 19: 55-70. _www.mapress.com/phytotaxa/

Chase, M.W. \& Reveal, J.L., 2009. A phylogenetic classification of the land plants to accompany APG III. Botanical Journal of the Linnean Society, 161(2): 122-127.

Comble J., de la, Koeniguer, J.C. \& Privé, C., 1973. Présence d'un bois de pin dans le Neogene de DiousurLoire. Bulletin d'Histoire Naturelle d'Autun, 65: 1-3.

Conwentz, H., 1884. Sobre algunos árboles des Rio Negro. Boletin de la Academia Nacional de Ciencias, Córdoba, 7: 435-456.

Crivellaro, A. \& Schweingruber, F.H., 2013. Atlas of Wood, Bark and Pith Anatomy of Eastern Mediterranean Trees and Shrubs, with special focus on Cyprus. Springer-Verlag Berlin Heidelberg. DOI 10.1007/978-3-642-37235-3

Cronquist, A., Takhtajan, A. \& Zimmermann, W., 1966. On the Higher Taxa of Embryobionta. Taxon. 15(4): 129-134. doi:10.2307/1217531; JSTOR $\underline{121753}$

Del Moro, A., Innocenti, F., Kyriakopoulos, C., Manetti, P. \& Papadopoulos, P., 1988. Tertiary granitoids from Thrace (Northern Greece): Sr isotopic and petrochemical data. Neues Jahrbuch für Mineralogie (Abhandlungen), 159: 113-135.

Desplats, D., 1983. Tetraclinoxylon amedroi n. sp. bois fossile de l'albien du Pas-de-Calais. 108e Congrès national des Sociétés savantes, Grenoble, 1983, sciences, fasc. I, t. 2: 143-152.

Dolezych, M. 2005. Koniferenhölzer im Lausitzer Flöz und ihre ökologische Position. Ph.D. thesis, Department of Botany, University of Utrecht, Utrecht. LLP Contributions, Series No. 19, pp. 1-339. Google Scholar

Dolezych, M., 2011. Taxodiaceous woods in Lusatia (Central Europe), including curiosities in their nomenclature and taxonomy, with a focus on Taxodioxylon. Japanese Journal of Historical Botany, 19(1-2): 25-46. https://www.researchgate.net/publication/279994414 
Dolezych, M., 2016. A remarkable extinct wood from Lusatia (central Europe) - Juniperoxylon schneiderianum sp. nov. with affinity to Cupressospermum saxonicum Mai. Palaeontographica B 295: 5-31.

Dolezych, M. \& van der Burgh, J., 2004. Xylotomische Untersuchungen an inkohlten Hölzern aus dem Braunkohltegebau Berzdorf (Oberlausitz, Deutschland). Feddes Repertorium 115: 397-342.

Dolezych, M. \& Schneider, W., 2005. Taxonomie und Taphonomie von Braunkohlenhölzern und Cuticulae dispersae von Koniferen im 2. Lausitzer Flözhorizont (Miozän) des Senftenberger Reviers. LPP Contributions Series, 19: 1-95.

Dolezych, M. \& Schneider, W., 2006a. Inkohlte Hölzer und Cuticulae dispersae aus dem 2. Miozänen Flözhorizont im Tagebau Welzow (Lausitz) - Taxonomie und vergleichende feinstratigraphisch-fazielle Zuordnung. Zeitschrift für Geologische Wissenschaften, 34, 165-259.

Dolezych, M. \& Schneider, W., 2006b. Xylotomie und feinstratigraphisch-fazielle Zuordnung von inkohlten Hölzern und dispersen Kutikulen aus dem 2. Lausitzer Flöz (Miozän) im Tagebau Welzow. Zeitschrift für geologische Wissenschaften 34: 165-259. Google Scholar.

Dolezych, M. \& Schneider, W., 2007. Taxonomie und Taphonomie von Koniferenhölzern und Cuticulae dispersae im 2. Lausitzer Flözhorizont (Miozän) des Senftenberger Reviers. Palaeontographica, (B), 276: $1-95$.

Dolezych, M., Fischer, T. \& Gröschke, A., 2011. Pinuxylon succiniferum (Goeppert) Kraeusel emend. Dolezych - amberized wood from Goeppert's type material restudied. Mauritiana (Altenburg), 22: 4360.

Dolezych, M., Reinhardt, L., Kus, J. \& Annacker, V., 2018. Taxonomy of Cretaceous-Paleogene coniferous woods and their distribution in fossil Lagerstätten of the high latitudes. (In Circum-Arctic structural events: tectonic evolution of the Arctic margins and transArctic links with adjacent orogens. Edited by K. Piepjohn, J.V. Strauss, L. Reinhardt, and W.C. McClelland). Geological Survey of America Special Paper, No. 541, pp. 1-36.

Dolezych, M. \& Reinhardt, L., 2020. First evidence for the conifer Pinus, as Pinuxylon selmeierianum sp. nov., during the Paleogene on Wootton Peninsula, northern Ellesmere Island, Nunavut, Canada. Canadian Journal of Earth Sciences, 57(1): 25-39. https://doi.org/10.1139/cjes-2018-0163; www.nrcresearchpress.com/cjes

Dupéron-Laudouéneix, M., 1979. Étude d'un bois homoxylé du Tertiaire de Charente. 104e Congrés national des sociétés savantes, Bordeaux, 1979, sciences, I: 249-261.

Earle, C.J., (Ed.), 2018. Gymnosperm Database (1998). Internet Online: https://www.conifers.org/
Erdei, B., Dolezych, M. \& Hably, L., 2009. The buried Miocene forest at Bükkábrány, Hungary. Review of Palaeobotany and Palynology, 155(1-20): 69-79. http://dx.doi.org/10.1016/j.revpalbo.2009.01.003

Esau, K. 1965. Plant anatomy. McGraw-Hill, New York.

Esteban, L.G., Gasson, P., Climent, J.M., de Palacios, P. \& Guindeo, A., 2005. The wood of Pinus canariensis and its resinous heartwood. IAWA Journal, 26 (1): 69-77

Esteban, L.G., Martin, J.A., de Palacios, P., GarciaFernandez, F. \& Lopez, R., 2010. Adaptive anatomy of Pinus halepensis trees from different Mediterranean environments in Spain. Trees, 24:19-30. https://doi.org/10.1007/s00468-009-0375-3

Fairon-Demaret, M., 1992. A propos de la découverte de Juniperoxylon pachyderma (Göppert) Kräusel 1949 dans le Tertiaire de Bioul (Entre-Sambre-etMeuse). Annales de la Société géologique de Belgique, 115(1): 333-339. URL : https://popups.uliege.be/0037-

9395/index.php?id=1645\&file=1\&pid=1643

Fairon-Demaret, M., Steurbaut, E., Damblon, F., Dupuis, C., Smith, T. \& Gerrienne, P., 2003. The in situ Glyptostroboxylon forest of Hoegaarden (Belgium) at the Initial Eocene Thermal Maximum (55 Ma). Review of Palaeobotany and Palynology, 126(1-2): 103-129. www.sciencedirect.com, www.elsevier.com/locate/revpalbo

Farjon, A., 2001. World Checklist and Bibliography of Conifers. 2. ed., 309 pp. The Royal Botanic Gardens, Kew. ISBN 1-84246-025-0

Farjon, A., 2005a. Monograph of Cupressaceae and Sciadopitys. Royal Botanic Gardens, Kew. ISBN 184246-068-4.

Farjon, A., 2005b. Pines. Drawings and descriptions of the genus Pinus, ed.2. Brill, Leiden ISBN 90-0413916-8.

Farjon, A., 2010. A Handbook of the World's Conifers. Leiden, Netherlands: Brill Academic Publishers.

Farjon, A., 2017. A Handbook of the World's Conifers (2 vols.), Vol. I. Revised and Updated Edition. Brill Leiden-Boston: $1153 \mathrm{p}$

Flinche, P., 1898. Note sur les bois fossiles de Metelin. In: De Launay L. (ed.) - Études géologiques sur la Mer Egée. La géologie des îles de Mételin, Lemnos et Thasos. Annales des Mines, 2: 141-151.

Gadek, P.A., Alpers, D.L., Heslewood, M.M., \& Quinn, C.J., 2000. Relationships within Cupressaceae sensu lato: a combined morphological and molecular approach. American Journal of Botany 87: 1044-1057

Gernandt, D.S., López, G.G., Garcías, O. \& Liston, A., 2005. "Phylogeny and classification of Pinus". Taxon. 54(1): 29-42. doi:10.2307/25065300. JSTOR 25065300.

Givulescu, R., 1997. The history of the Tertiary Fossil Forests from Transylvania, Banat, Crişana and 
Maramureş (Romania). Editura Carpatica, Cluj Napoca, 1-172 pages, 27 pl. [in Romanian].

Göppert, H.R. \& Berendt, G., 1845. Der Bernstein und in ihm befindliche Pflanzenreste der Vorwelt. - Nicolaische Buchhandlung, Berlin, 125 pp.

Göppert, H.R., 1850. Monographie der fossilen Koniferen. 286 pp. Arnz \& Comp., Leiden.

Gorozhankin, I.N., 1904. Lektsii po morfologii i sistematike archegonialnyh rastenij. II, Pteridophyta, I, Archispermae. 104 pp. A.I. Mamontov, Moskva. [in Russian]

Gothan, W., 1905. Zur Anatomie lebender und fossiler Gymnospermen-Hölzer. Abhandlungen der Königlich Preussischen Geologischen Landesanstalt, 44: 1-108.

Gothan, W. 1906: Die fossilen Coniferenhölzer von Senftenberg. - Abhandlungen der Königlich Preussischen Geologischen Landesanstalt. N.F., 46: 155-171.

Gottwald, H., 1966. Eozäne Hölzer aus der Braunkohle von Helmstedt. Palaeontographica Abt.B, 119(1-3): 76-93, 3 Taf., Stuttgart

Gottwald, H., 1992. Hölzer aus marinen Sanden des oberen Eozän von Helmstedt (Niedersachsen). Palaeontographica, B, 225(1-3): 27-103.

Grambast, L., 1951. Tetraclinoxylon (Cupressinoxylon p.p.) boureaui n.gen.et n.sp., bois fossile du Chatien du Bassin de Paris. Bulletin de la Societé géologique de France, $6^{\mathrm{e}}$ serie, 1: 277-284, 4 fig., 4 tabl. Paris.

Grambast, L., 1962. Flore de l'Oligocène supérieur du Bassin de Paris. Annales de Paléontologie, XLVIII: 85-162, pl. I-X, Paris.

Grambast, L., 1954. Un Juniperoxylon particulier de l'Eocène inférieur du Bassin de Paris. Archives du Muséum National du Paris, 3: 1-21.

Gray, S.F., 1822. Natural Arrangement of British Plants, According to Their Relation to Each Other. Vol. 2., 760 pp. Baldwin, Cradock, and Joy, London.

Greguss, P. 1954. Az Ipolytarnóc alsó-miocén kövesedett famaradványok (Remains of silicified woods of the lower Miocene of Ipolytarnóc). Földtani Közlöny (= Bulletin of Hungarian Geological Society), 84: 91109. [in Hungarian].

Greguss, P., 1955. Identification of living Gymnosperms on the basis of xylotomy. Akádemiai Kiádo, 350 pl., 8 tab., Budapest.

Greguss, P., 1962. Le genre Ducampopinus est-il valable en vertu de sa xylotomie? Travaux du Laboratoire Forestier de Toulouse, 6: 1-6.

Greguss, P., 1967. Fossil Gymnosperm Woods in Hungary from the Permian to the Pliocene. Akadémiai Kiadó, Budapest.

Greguss, P., 1972. Xylotomy of the Living Conifers. 501 p., Akademiai Kiado, Budapest.

Gryc, V. \& Sakala, J., 2010. Identification of fossil trunks from Bükkábrány newly installed in the Visitor Centre of the Ipolytarnóc Fossils Nature Reserve (No- vohrad - Nógrád Geopark) in Northern Hungary. Acta Universitatis Agriculturae et Silviculturae Mendelianae Brunensis, 58:117-122. http://ipolytarnoc.kvvm.hu/uploads/File/pdf/Sakala_a cta_bukkabrany.pdf

Güngör, Y., Akkemik, Ü., Kasapçi, C. \& Başaran, E., 2019. Geology and woods of a new fossil forest from the Early Miocene of Gökçeada (Turkey). Forestist, 69(1): 22-34.

Hartig, T., 1848. Beiträge zur Geschichte der Pflanzen und zur Kenntnis der norddeutschen Braunkohlen Flora. Botanische Zeitung (Berlin), 6: 122-190.

Havelcová, M., Sýkorová, I., Bechtel, A., Mach, K., Trejtnarová, H., Žaloudková, M., Matysová, P., Blažek, J., Boudová, J. \& Sakala, J., 2013. Stump Horizon" in the Bílina Mine (Most Basin, Czech Republic) - GC-MS, optical and electron microscopy in identification of wood biological origin. International Journal of Coal Geology, 107(1): 62-77. https://doi.org/10.1016/j.coal.2012.09.008

Henry, A. \& McIntyre, M., 1926. The swamp cypresses, Glyptostrobus of China and Taxodium of America, with notes on allied genera. Proceedings of the Royal Irish Academy v. 37(B-13): 90-116, 8 plates.

Hofmann, E., 1952. Pflanzenreste aus dem Phosphoritvorkommen, von Prambachkirchen Im Oberöstereich, II Teil. Palaeontographica, Abt. B, Paläophytol. 92(3-6): 122-138.

Houlbert, C. 1910. Les bois des faluns de Touraine. Pp. 70-76 in: Lecointre, H.D. comtesse P. (ed.), Les formes diverses de la vie dans les Faluns de Touraine. Sixième suite. Feuille des Jeunes Naturalistes, 473: 69-76.

Huard, J., 1966. Étude anatomique des bois de conifères des couches à lignite néogènes des Landes. Mémoires de la Société géologique de France, 105: 1-85.

Huard, J., 1967. Étude d'un bois de chêne provenant des couches a lignite d'Arjuzans (Landes). Bulletin du Muséum National d'Histoire Naturelle sr. 2, 38(6): 969-978.

Hudson, R.H. 1960. The anatomy of the genus Pinus in relation to its classification. Journal of the Institite of Wood Science, 6: 26-46.

Iamandei, E. \& Iamandei, S., 2000a. Bois fossiles de Coniferes dans l'Aptien de Dobroudja du sud, Roumanie. Acta Paleontologica Romaniae, 2: 191- 199.

Iamandei, S. \& Iamandei, E., 2000b. Fossil Conifer Wood from Prăvăleni - Ociu, Metalliferous Mountains. Acta Palaeontologica Romaniae, 2: 201-212.

Iamandei, E. \& Iamandei, S., 2006, Early Cretaceous Protopinaceous Fossil Wood from South Dobrogea, Romania. Acta Paleontologica Romaniae, 5: 231-247.

Iamandei, S. \& Iamandei, E., 2008a. New trees within the Mid-Miocene petrified forest from Zarand, Apuseni mts., Romania. Revue Roumaine de Géologie, Acad. Roum., 50-52/(2006-2008): 69-86. 
Iamandei, S. \& Iamandei, E., 2008b. Neogene Tetraclinoxylon within Carpathian area. Revue Roumaine de Géologie, 50-52(2006-2008): 55-68.

Iamandei, E. \& Iamandei, S., 2008c. Late Cretaceous Fagaceae in the South Apuseni mts., Romania. Studii şi Cercetări de geologie, 51-53(2006-2008): 59-75.

Iamandei, S. \& Iamandei, E.P., 2010. Trésors du fond des bois d'autrefois (Bois pétrifiés du Musée National de Géologie de Bucarest). In «Le patrimoine paléontologique - Des trésors du fond des temps» (Eds: Saint-Martin J-P., Saint-Martin S., Oaie, G., Seghedi, A. \& Dan Grigorescu, D.): 47-57

Iamandei, S. \& Iamandei, E., 2017. New trees identified in the Petrified Forest of Middle Miocene from Zarand, Apuseni Mountains, Romania. Acta Palaeontologica $\quad$ Romaniae, $13(2)$ : 37-90. https://actapalrom.geo-

paleontologi-

ca.org/APR_v_13_2/Iamandei_Iamandei_Zarand.pdf

Iamandei, S., Iamandei, E. \& Ionesi, V., 2001a. Sarmatian fossil wood from from Fălticeni-Suceava region. Analele Ştiinţifice ale Universităţii "Al. I. Cuza" din Iaşi (sr.n.), Geologie, 47: 235-240.

Iamandei, S., Iamandei, E. \& Lupu, A.I., 2001b. Some fossil woods in the Iaşi Botanical Garden. Analele Ştiinţifice ale Universităţii "Al. I. Cuza" din Iaşi (sr.n.), Geologie, 47: 267-274.

Iamandei, S., Iamandei, E. \& Ţibuleac, P., 2001c. Fossil Wood from Coal-layer "B" of Volhinian Formation in Leucuşeşti - Fălticeni area. Analele Ştiinţifice ale Universităţii "Al. I. Cuza" (sr.n.), Geologie, 47: 211218.

Iamandei, S., Iamandei, E. \& Ţibuleac, P., 2004. New fossil wood from the Late Badenian Forest of Prăvăleni, Metalliferous Mts. (1st Part). Analele ştiinţifice ale Universităţii “Al. I. Cuza” Iaşi, Geologie, 49- 50/(2003-2004): 235-246.

Iamandei, S., Iamandei, E. \& Ţibuleac, P., 2005a. New fossil wood from the Late Badenian Forest of Prăvăleni, Metalliferous Mts. ( $2^{\text {nd }}$ Part). Analele ştiinţifice ale Universităţii “Al. I. Cuza”, Iaşi, Geologie, 51: 111-124.

Iamandei, S., Iamandei, E. \& Obada, T., 2005 b. Sarmatian Petrified wood within "Bursuc Flora" (Moldova Rep.). Acta Paleontologica Romaniae, 5: 223-229. http://www.geopaleontologica.org/page7/Iamandei_etal_pdf.pdf

Iamandei, S., Iamandei, E. \& Ionesi, V., 2008a. New petrified woods within Sarmatian Şomuz Formation, NE Romania. In: Acta Palaeontologica Romaniae, 6: 137144.

http://www.geopaleontologica.org/page8/Iamandei_et al1.pdf

Iamandei, S., Iamandei, E., Obadă, T., Lungu, A. \& Postolachi, V., 2008b. New Sarmatian Petrified Woods from Moldova Republic. Acta Palaeontologica
Romaniae 6: 201-212. url: https://actapalrom.geopaleontologica.org/APR_vol_6/Iamandei_etal2.pdf

Iamandei, E., Iamandei, S. \& Diaconu, F., 2011. Fossil woods in the collection of Drobeta - Tr. Severin $\mathrm{Mu}-$ seum. Acta Palaeontologica Romaniae, 7: 199-218. http://www.geopaleontologica.org/page13/18_Iamand ei-1.pdf

Iamandei, S., Iamandei, E., Frunzescu, D. \& Brănoiu, G., 2012a. New petrified woods from the Curvature Carpathians. Romanian Journal of Earth Sciences, vol. 86(2): 67-89.

Iamandei, S., Iamandei, E. \& Velitzelos, E., 2012b. Identification of a fossil trunk from Achlada mine (Florina, Greece), newly installed at the entrance of the coal mine. Romanian Journal of Earth Sciences, 86(1): 41-49. https://www.researchgate.net/publication/288636669_ identifica-

tion_of_a_fossil_trunk_from_achlada_mine_florina_g reece_newly_installed_at_the_entrance_of_the_coal_ mine

Iamandei, S., Iamandei, E. \& Sabou-Dumitrescu, M., 2013. New petrified woods from Căprioara Valley, Feleacu Hill, Cluj, Romania. Romanian Journal of Earth Sciences, 87(1): 1-27.

Iamandei, S., Iamandei, E., Bozukov, V. \& Tsenov, B., 2014. Oligocene fossil wood from Rhodopes, Bulgaria. Acta Palaeontologica Romaniae, 9(2): 15-25. https://actapalrom.geopaleontologica.org/APR_v_9_2/03_Iamandei_et_al.pdf

Iamandei, S., Iamandei, E., Bozukov, V. \& Tsenov, B.., 2016. New Oligocene fossil woods from Rhodopes, Bulgaria. Acta Palaeontologica Romaniae, 12(2): 47 65. https://actapalrom.geopaleontologica.org/APR_v_12_2/Iamandei_Bulgaria.pdf

Iamandei, S., Iamandei, E. \& Stoia, T., 2020a. Fossil woods from Bozovici (SW Romania). Acta Palaeontologica $\quad$ Romaniae, 16(1): $3 \quad$ - 17. https://actapalrom.geopaleontologica.org/APR_v_16_1/Iamandei_Bozovici.pdf

Iamandei, S., Iamandei, E. \& Todea, P., 2020b. Palaeoxylotomical study of a new collection from Zarand Miocene Petrified Forest, South Apuseni mts. Acta Palaeontologica Romaniae, 16(1): $19 \quad$ - 34. https://actapalrom.geopaleontologica.org/APR_v_16_1/Iamandei_Zarand.pdf

IAWA Committee, 2004. IAWA List of microscopic features for softwood identification (H.G. Richter, D. Grosser, I. Heinz \& P.E. Gasson editors). IAWA Journal, 25 (1): 1-70. https://www.iawawebsite.org/uploads/soft/Abstracts/01_IAWASoftwood_List.pdf 
Ibrahim, A., 2015. Late Cretaceous conifer woods of Terlingua ranch, Brewster county, Texas A. M.S. Thesis in Biology, Texas State University.

Ickert-Bond, S.M., 2001. Reexamination of wood anatomical features in Pinus krempfii (Pinaceae). IAWA Journal, 22(4): 355-365

ING Database - Index Nominum Genericorum - A compilation of generic names published for organisms covered by the ICN: International Code of Nomenclature for Algae, Fungi, and Plants. [Farr, E. R. \& G. Zijlstra, eds. 1996 - Index Nominum Genericorum (Plantarum). http://botany.si.edu/ing/]. The Smithsonian National Museum of Natural History. https://naturalhistory2.si.edu/botany/ing/

Innocenti, F., Kolios, N., Manetti, P., Mazzuoli, R., Peccerillo, A., Rita, F. \& Villari, L., 1984. Evolution and geodynamic significance of Tertiary orogenic volcanism in northeastern Greece. Bulletin of Volcanology, 47: 25-37.

Innocenti, F., Manetti, P., Mazzuoli, R., Pertusati, P., Fytikas, M. \& Kolios, N., 1994. The geology and geodynamic significance of the Island of Limnos, North Aegean Sea, Greece. Neues Jahrbuch für Mineralogie, Geologie und Paläontologie. Monatshefte, 11: 661691.

INSIDEWOOD, 2004-onwards. Published on the Internet. http://insidewood.lib.ncsu.edu/search [18.12.2020].

IFPNI - International Editorial Board, 2014. The International Fossil Plant Names Index. Available from: https://www.fossilplants.info. (Accessed 2021-03-05). www.fossilplants.info/genus.htm?id=A48740B5FE7F-4372-97AE-B8347A608650

Jane, F.W., 1956. The structure of wood. MacMillan Co., New York

Jarmolenko, A., 1934. On the fossil woods from the Cheleken Islands [in Russian]. Trudy neftanogo nauchno-issledovatel'skogo geologorazvedochnogo instituta (VNIGRI), 48: 20-22. [in Russian].

Jolivet, L. \& Brun, J-P., 2010. Cenozoic geodynamic evolution of the Aegean. International Journal of Earth Sciences (Geol Rundsch), 99: 109-138. DOI 10.1007/s00531-008-0366-4

Jurasky, K.A., 1933. Glyptostroboxylon tenerum (Kraus) Conwentz in der oberpliozanen Braunkohle von Woelfersheim (Wetterau). Braunkohle, 40: 746-750.

Katsikatsos, G., Mataragas, D., Migiros, G. \& Triantaphyllis, E., 1982. Geological study of Lesbos Island. IGME - Internal report, Athens. p. 92. [in Greek].

Katsikatsos, G., Migiros, G., Triantaphyllis, M. \& Mettos, A., 1986. Geological structure of internal Hellenides (E. Thessaly - SW Macedonia - Euboea - Attica - northern Cyclades Islands and Lesbos). IGMEAthens, Geological \& Geophisical Researches, Sp. Vol.: 191-212.
Kłusek, M., 2014. Miocene coniferous woods of the Polish Carpathian Foredeep. Acta Palaeontogica Polonica, 59: 697-708.

Knowlton, F.H., 1900. Description of a new genus and species of conifer wood from the Jurassic of the Black Hills. In: Ward, L.F.(Ed.), Status of the Mesozoic floras of the United States - the older Mesozoic. Twentieth annual report of the United States Geological Survey, 2: 420-422.

Koch, K.H.E., 1873. Dendrologie 2(2). Bäume, Sträucher und Halbsträucher, welche in Mittel- und NordEuropa im Freien kultivirt werden. 2.vol. (Kritisch beleuchtet von Karl Koch, p.186).

Koeniguer, J.C. 1967. Étude paléoxylologique du Rio de Oro. Not. Com. Inst. Geol. Min. Espana 96: 39-66. Sahara occidental (Rio de Oro) Néogêne.

Kopp, K.O. 1965. Geologie Thrakiens III: Das Tertiär zwischen Rhodope und Evros. Annales Géologiques des Pays Helléniques, 16: 315-362.

Kostyniuk, M. 1967. Pnie drzew iglastych z górnego pokładu węgla brunatnego w Turowie. Prace Muzeum Ziemi (in Polish $=$ Trunks of coniferous trees from the upper brown coal seam in Turów. Works of the Earth Museum), 10: 3-96.

Koufos, G.D., Zouros, N. \& Mourouzidou, O., 2003. Prodeinotherium bavaricum (Proboscidea, Mammalia) from Lesvos Island, Greece; the appearance of deinotheres in the Eastern Mediterranean. Geobios, 36: $305-315$.

Koutecký, V. \& Sakala, J., 2015. New fossil woods from the Paleogene of Doupovské hory and České středohoří Mountains (Bohemian Massif, Czech Republic). Acta Musei Nationalis Pragae, Series B Historia Naturalis, 71(3-4): 377-398.

Koutecký, V., Teodoridis, V., Čáp, P., Mantzouka, D. \& Sakala, J., 2019. Fossil wood from the Doupovské hory and České středohoří volcanic complexes: latest overview and new angiosperms from the locality Dvérce. Neues Jahrbuch für Geologie und Paläontologie - Abhandlungen, 293/3: 283-306, Stuttgart.

Kovar-Eder, J. \& Kvaček, Z., 1995. Der Nachweis eines fertilen Zweiges von Tetraclinis brachyodon (Brongniart) Mai et Walther aus Radoboj, Kroatien (Mittel-Miozän). Flora - Morphology Distribution Functional Ecology of Plants, 190(3): 261-264. Gustav Fischer Verlag Jena. DOI: 10.1016/S03672530(17)30662-X

Kownas, S. 1951. Trzeciorzędowe drewna z Dobrzynia nad Wisłą. Studia Societatis Scientiarum Toruniensis 1: 67-121.

Kramer, K., 1974. Die Tertiären Hölzer Südost-Asiens (Unter Ausschluss der Dipterocarpaceae) 1 Teil. Palaeontographica, B, 144(3-6): 45-181.

Kraus, G., 1864: Mikroskopische Untersuchungenüber den Bau lebender und vorweltlicher Nadelhölzer. Würzburger Naturwiss. Z., 5: 44-200 
Kraus, G., 1870. Bois fossiles de Conifères. In: Schimper W.P., Traité de Paléontologie Végétale, 2: 363-385, Strasbourg (Baillière).

Kraus, G., 1886. Beiträge zur Kenntnis fossiler Hölzer. I. II. Abhandlungen der Naturforschenden Gesellschaft zu Halle, XVI. Halle 1886. III. IV. desgl. XVII. 1888.

Kräusel, R. 1913. Beiträge zur Kenntnis der Hölzer aus der schlesischen. Braunkohle I. 56 pp. Inaugural Dissertation, W.G. Korn, Breslau.

Kräusel, R. 1919. Die fossilen Koniferenhölzer (unter Auschluß von Araucarioxylon Kraus). I: Versuch einer monographischen Darstellung. Palaeontographica, 62: 185-284.

Kräusel, R. 1920. Nachträge zur Tertiärflora Schlesiens II. Braunkohlenhölzer. Jahrbuch der preußischen geologischen Landesanstalt, 39: 418-460.

Kräusel, R. 1949. Die fossilen Koniferen-Hölzer (Unter Ausschluß von Araucarioxylon Kraus). II: Kritische Untersuchungen zur Diagnostik lebender und fossiler Koniferen-Hölzer. Palaeontographica B, 89: 83-203.

Kunzmann, L. 1999. Koniferen der Oberkreide und ihre Re21 9-222. 1 likte im Tertiar Europas. ein Beitrag zur Kenntnis ausgestorbener Taxodiaceae und Geinitziaceae fam. nov. - Abhandlungen Staatliches $\mathrm{Mu}-$ seum für Mineralogie und Geologie, Dresden, 45: 1138.

Kvaček, J., 1999. Two conifers (Taxodiaceae) of the Bohemian Cenomanian (Czech Republic, Central Europe). Acta Palaeobotanica, suppl. 2:129-151.

Kvaček, Z., 2002. A new juniper from the Palaeogene of Central Europe. Feddes Repertorium, Journal of Botanical Taxonomy and Geobotany, 113(7-8):492-502. https://doi.org/10.1002/fedr.200290001

Kvaček, Z. \& Bůžek Č., 1982. Třetihorní rostlinná společenstva severočeské hnědouhelné pánve ve vztahu k litofaciální vývoji. 46 pp. Praha (Ústřední ústav geologický) [in Czech]. (=Tertiary plant communities of the North Bohemian brown coal basin in relation to lithofacial development. - 46 pp., Prague (Central Institute of Geology).

Kvaček, Z. \& Hably, L., 1998. New plant elements in the Tard Clay Formation from Eger-Kiseged. Acta Palaeobotanica, 38(1): 5-23, Krakow.

Kvaček, Z., Manchester, S.R. \& Schom, H.E., 2000. Cones, ds, and foliage of Tetraclinis salicornioides (Cupressaceae) from the Oligocene and Miocene of western North America: a geographic extension of the European Teriary species. International Journal of Plant Sciences, 161: 331-344, Univ. Chicago Press.

Kvaček, Z., Walther, H. \& Bůžek, C., 1989. Paleogene floras of W. Bohemia (CSSR) and the Weisselster Basin (GDR) and their correlation. Casopis pro mineralogii a geologii, 34(4): 385-401, Praha.

Lecointre, G. \& Koeniguer, J.C., 1965. Determination d'un bois fossile recolte au Rio de Oro. Notas y Comunicaciones del Instituto Geológico y Minero de España, Madrid, 80: 95-100.
Lemoigne, Y. 1967a. Paléoflore à Cupressales dans le Trias-Rhétien du Cotentin. Comptes Rendus hebdomadaires des séances de l'Académie des sciences, 264: $715-718$.

Lemoigne, Y., 1967b. Bois de structure gymnospermienne provenant du Vraconnien de la région de Blieux (Basses-Alpes). Bulletin de la Société géologique de France, 9: 476-480.

Li, L., Jin, J-H. \& Manchester, S.R., 2018. Cupressaceae fossil remains from the Paleocene of Carneyville, Wyoming. Review of Palaeobotany and Palynology, 251:1-13. https://doi.org/10.1016/j.revpalbo.

Lindley, J., 1836. A Natural System of Botany. A Systematic View of the Organisation, Natural Affinities, and Geographical Distribution, of the Whole Vegetable Kingdom. Published in London, by: "Longman, Rees, Orme, Brown, Green \& Longman”.

Link, J.H.F. 1829. Handbuch zur Erkennung der nutzbarsten und am haüfigsten vorkommenden Gewächse, Berlin. V. 2, p. 470.

Mai, D.H. \& Walther, H., 1978. Die Floren der Haselbacher Serie im Weißelster-Becken (Bezirk, Leipzig, D.). Abhandlungen des Staatlichen Museums Mineralogie und Geologie Dresden, 28: 1 - 200.

Mantzouka, D. 2009. Palaeogeographical study of Lapsarna area (Lesbos Island) based on the new palaeontological findings of the lower Miocene period, Master thesis, Department of Geography. University of Aegean. p.p. 143 (in Greek).

Mantzouka, D., Sakala, J., Kvaček, Z. \& Karakitsios, V., 2013. Palaeobotanical study of Polichnitos region, southern part of Lesbos Island, Greece (preliminary results on angiosperm wood). Bulletin of the Geological Society of Greece, 47(1): 204-215. DOI: 10.12681/bgsg. 10928

Mantzouka, D., Karakitsios, V. \& Sakala, J., 2017. Cedroxylon lesbium (Unger) Kraus from the Petrified Forest of Lesbos, lower Miocene of Greece and its possible relationship to Cedrus. Neues Jahrbuch für Geologie und Paläontologie - Abhandlungen, 284(1): 75-87.

Mantzouka, D., Sakala, J., Kvaček Z., Koskeridou, W. \& Ioakim, C., 2019a. Two fossil conifer species from the Neogene of Alonissos Island (Iliodroma, Greece). Geodiversitas $\quad$ 41(1): 125-142. https://doi.org/10.5252/geodiversitas2019v41a

Mantzouka, D., Sakala, J., Kvaček, Z, Koskeridou, E. \& Karakitsios, V. 2019b. Petrified Forest of Lesbos Island (Greece): A palaeobotanical puzzle of a unique Geopark and the new discoveries. 2019 IOP Conf. Ser.: Earth Environmental Sciences, 221. 012146 https://iopscience.iop.org/article/10.1088/17551315/221/1/012146/pdf

Mao, K., Hao, G., Liu, J., Adams, R.P. \& Milne, R.I., 2010. Diversification and biogeography of Juniperus (Cupressaceae): Variable diversification rates and 
multiple intercontinental dispersals. New Phytology, 188: $254-272$.

Mao, K.; Milne, R. I., Zhang, L., Peng, Y., Liu, J., Thomas, P., Mill, R.R. \& Renner, S., 2012. Distribution of living Cupressaceae reflects the breakup of Pangea. Proceedings of the National Academy of Sciences, 109 (20): 7793-7798. doi:10.1073/pnas.1114319109; ISSN 0027-8424. PMID 22550176.

Martinetto, E., 1994. Paleocarpology and the "in situ" ancient plant communities of a few Italian Pliocene fossil forests. In: Matteucci Carboni, R., Carboni, M.G., Pignatti, J.S. (Eds.), Studies on Ecology and Paleoecology of Benthic Communities. Bollettino della Società Paleontologica Italiana, Spec. vol. 2. pp. 189-196.

Mathiesen, F. J., 1970. Palaeobotanical Investigations into some Cormophytic Macrofossils from the Neogene Tertiary Lignites of Central Jutland. Part II. Gymnosperms. Biologiske Skrifter udgivet af Det Kongelige Danske Videnskabernes Selskab, 17(3), 169.

Medlyn, D.A. \& Tidwell, W.D., 1979. A review of the genus Protopiceoxylon with emphasis on North American species Canadian Journal of Botany, 57(13):1451-1463; https://doi.org/10.1139/b79-179

Mustoe, G., 2018. Non-mineralized Fossil Wood. Geosciences $\quad$ (Switzerland), 8(223): $1-30$. DOI: $10.3390 /$ geosciecnes8060223

Müller-Stoll, W.R. \& Schultze-Motel, J., 1990. Gymnospermen-Hölzer des deutschen Jura. Teil 3: Abietoid (modern) getüpfelt Hölzer. Zeitschrift der deutschen geologischen Gesellschaft, 141: 61-77.

Nagy, F., 1969. Verkieselte Sequoia-reste aus dem Nordsiebenburgischen oberen Oligozan. Revue Roumaine de Biologie - Botanique, 14: 211-214.

Nagy, F., Petrescu, I. \& Mârza, I., 2002. La présence d'un bois de Glyptostroboxylon dans le miocène de Prăvăleni - Brad. Contribuţii Botanice, 37: 293-298.

Nastschokin, V.-D., 1962. Fossil woods from Cretaceous sediments. Trudy sibirskogo naučnoissledovate'skogo instituta geologii, 22: 161-164. [in Russian]

Nishida, M. \& Nishida, H., 1985. Structure and affinities of the petrified plants from the Cretaceous of Northern Japan and Saghalien II. Petrified plants from the Upper Cretaceous of Hokkaido (2). Journal of Japanese Botany, 60: 312-320.

Özgenc, O., Durmaz, S., Serdar, B., Boyaci, I.H., Eksikocak, H. \& Öztürk, M., 2018. Characterization of fossil Sequoioxylon wood using analytical instrumental techniques. Vibrational Spectroscopy, Elsevier, 96: 10-18. https://doi.org/10.1016/j.vibspec.2018.02.006

Özgüven, K. 1971. Sur un bois fossile de Taxodiaceae dans la flore Neogene d'Istanbul (Turquie d'Europe): Sequoioxylon egemeni n.sp. Istanbul Univ. Fak.
Mecm., B (=Revue de la Faculté des sciences de l'Université d'Istanbul, Series B), 36: 89-114 (in Turkish).

Özgüven-Ertan, K., 1977. La stucture d'une Cupressaceae fossile appartenant au Miocene Trouvée dans la region d'Egee, en Turquie: Cupressinoxylon akdiki n.sp. Revue de la Faculté des sciences de l'Université d'Istanbul Series B, 42 (B1-2): 1-15.

Panshin, A.J. \& DeZeeuw, C., 1980. Textbook of wood technology. McGraw-Hill Book Company, New York

Patel, R.J., 1971. Epidermal structure and development of stomata in some Annonaceae. Annals of Botany, 35: 1205- 1212 .

Pe-Piper, G., 1980b. The Cenozoic volcanic sequence of Lesbos, Greece. Zeitschrift der Deutschen Geologischen Gesellschaft, 131: 889-901.

Pe-Piper, G. \& Piper, D.J.W., 1993. Revised stratigraphy of the Miocene volcanic rocks of Lesbos, Greece. Neues Jahrbuch für Geologie und Paläontologie/Monatshefte, H.2: 97-110.

Petrescu, I., 1978. Study of fossil woods from the Oligocene of North-western Transylvania. Mémoires de l'Institut de Géologie et de Géophysique, 27: 115184. [in Romanian].

Petrescu, I. \& Nuţu, A., 1970. Alte tipuri de lemne din Miocenul superior de la Prăvăleni-Brad. Sargetia (Acta Musei Devensis), sr. Sc. Nat., VII: 253-258, [in Romanian].

Petrescu, I. \& Bican-Brişan, N., 2004. The presence of some Pinuxylon Gothan, 1906 woods in the Badenian salt from Ocna Dej (NW Romania). Acta Palaeontologica Romaniae 4: 345-349

Petrescu, I. \& Dragastan, O., 1971. Results of the investigation of several tree trunk remnants from the Tertiary of Romania. Studii şi cercetări, geologie, geofizică, geografie, Seria geologie, 16(1): 265-271. [in Romanian].

Petrescu, I. \& Popa, V., 1971. Presence of Sequoioxylon gypsaceum (Goepp) Greguss in Petroşani Basin. Studia Universitatis Babeş-Bolyai, series GeologyMineralogy, 2: 57-62, (in Romanian).

Petrescu, I. \& Velitzelos, E., 1981. Quercoxylon intermedium n. sp. in Oligocenul din Tracia (Grecia de NordEst). [Q. intermedium n. sp. in the Oligocene of Thrace (northeastern part of Greece)]. Contribuţii botanice. Univ. Babeş-Bolyai Cluj, vol./1981: 9-16. [in Romanian].

Petrescu, I., Velitzelos, E. \& Stavropodis, I.D., 1980. The occurence of the genus Lithocarpoxylon Petrescu, 1978 (Fagaceae), in the Tertiary of Greece. Annales Géologiques des Pays Helléniques, 30: 366-379.

Philippe, M., 1993. Nomenclature générique des trachéidoxyles fossiles mésozoïques à champs araucarioïdes. Taxon 42(1): 74-80. - ISSN 0040-0262. https://doi.org/10.2307/1223305 
Philippe, M. \& Bamford, M.K., 2008. A key to morphogenera used for Mesozoic conifer-like woods. Review of Palaeobotany and Palynology, 148: 184-207. www.elsevier.com/locate/revpalbo

Philippe, M. \& Bamford, M., 2009. Houlbert's types for fossil wood: Lectotypification and taxonomic reappraisal of Abietoxylon. Taxon, 58(4):1349-1356 DOI: $10.1002 / \operatorname{tax} .584022$

Philippe, M., Bamford, M., McLoughlin, S., Alves, L.S.R., Falcon-Lang, H.J., Gnaedinger, S., Ottone, E.G., Pole, M., Rajanikanth, A., Shoemaker, R.E., Torres, T., \& Zamuner, A., 2004. Biogeographic analysis of Jurassic-Early Cretaceous wood assemblages from Gondwana. Review of Palaeobotany and Palynology, 129: 141-173.

Phillips, E.W.J., 1941. The identification of coniferous woods by their microscopic structure. The Journal of the Linnean Society. Botany, 52: 259-320.

Phillips, E.W.J., 1948. Identification of softwoods by their microscopic structure. Forest Research Bulletin, 46: $1-56$.

Peirce, A.S., 1937. Systematic anatomy of the woods of the Cupressaceae. Tropical Woods, 49: 5-21.

Polat, S., Güney, Y., Ege, İ. \& Akkemik, Ü., 2019. Banaz'da (Uşak) Yeni Bulunan Petrifiye Alanı ile İlgili İlk Bulgular. Coğrafi Bilimler Dergisi (=Turkish Journal of Geographical Sciences), 17(2): 384-402. [in Turkish]. doi: 10.33688/ aucbd.532176

Prill, W., 1913. Beiträge zur Kenntnis schlesischer Braunkohlenhölzer II. 68 pp. Inaugural Dissertation, W.G. Korn, Breslau.

Privé, C., 1973. Tetraclinoxylon vulcanense n. sp., bois fossile du Puy-de-Dôme. C.R. 96 ${ }^{\mathrm{e}}$ Congrès national des sociétés savantes, Toulouse, Sciences, 5: 165175.

Privé-Gill, C., 1977. Taxodioxylon gypsaceum (Goeppert) Kräusel, bois fossile du Tertiaire de Limagne (France). C. R. du $102^{\mathrm{e}}$ Congrés National des Sociétés Savantes, Limoges, 1977, Sciences, fasc. I: 187- 196.

Privé-Gill, C. \& Watelet, P., 1980. La brèche ponceuse du domaine d'Aubart (commune du Claux, Cantal). Volcano-stratigraphie et étude des bois fossiles. Comptes Rendus du $105^{\mathrm{e}}$ Congrés national des sociétés savantes, Caen, 1980, Sciences, fasc. I: 131-151.

Privé-Gill, C. \& Pelletier, H., 1981. Sur quelques bois silicifiés du Tertiaire de Limagne, dans la région d'Aiguerperse (Puy-de-Dôme), France. Review of Palaeobotany and Palynology, 34: 369-405.

Ramanujam, C.G.K., 1960. Silicified woods from Tertiary rocks of South India. Palaeontographica Abt. B., 106(4-6): 99-140.

Ramanujam, C.G.K. \& Stewart, W.N., 1969. Nomenclatural changes for Taxodioxylon antiquum Ramanujam \& Stewart and T. antiquum Prakash. Canadian Journal of Botany, 47(8): 1333-1334; https://doi.org/10.1139/b69-189
Ravazzi, C. \& van der Burgh, J., 1995. Coniferous woods in the Early Pleistocene brown coals of the Leffe basin (Lombardy, Italy). Ecological and biostratigraphic inferences. Rivista Italiana di Paleontologia e Stratigrafia, 100(4):597-620.

Reveal, J.L. 1996. Newly required suprageneric names in Magnoliophyta. Phytologia 79: 68-76.

Roy, S.K. \& Stewart, W.N., 1971. Oligocene woods from the Cypres Hills Formation in Saskatchewan, Canada. Canadian J. of Botany, 49: 1867-1877.

Roy, S.K. \& Hills, L.V., 1972. Fossil woods from the Beaufort Formation (Tertiary), northwestern Banks Island, Canada. Canadian Journal of Botany, 50(12): 2637-2648; https://doi.org/10.1139/b72-337.

Román-Jordán, E., Esteban, L.G., De Palacios, P. \& Fernández, F.G., 2016. Wood anatomy of Cupressus and its relation to geographical distribution. IAWA Journal, 37: 48-68.

Román-Jordán, E., Esteban, L.G., De Palacios, P. \& Fernández, F.G., 2017. Comparative wood anatomy of the Cupressaceae and correspondence with phylogeny, with special reference to the monotypic taxa. Plant Systematics and Evolution, 303: 203-219.

Röessler, W., 1937. Pliozäne Koniferenholzer der Umgebung von Glechenberg in Steiermark. Mitteilungen des Naturwissenschaftlichen Vereines für Steiermark, 74: 64-97.

Rudolph, K., 1935. Mikrofloristiche UntersuchungenTertiärer Ablagerungen im Nordlistchen Bohmen. Beihefte zum Botanische Zentralblatt, 54, 244-328.

Ruiz, D.P. \& Bodnar, J., 2019. The oldest record of Juniperoxylon, a cupressaceous fossil wood from the Middle Triassic of Argentina. Acta Palaeontologica Polonica, 64(3): 481-488.

Sakala, J., 2003. Podocarpoxylon helmstedtianum Gottwald from Kučlin (Late Eocene, Czech Rep.) reinterpreted as Tetraclinoxylon vulcanense PRIVÉ. Feddes Repertorium, 114(1-2): 25-29.

Sakala, J. 2004. The 'Whole-Plant' concept in palaeobotany with examples from the Tertiary of northwestern Bohemia, Czech Republic with particular reference to fossil wood, PhD Thesis, Université Pierre-et-Marie, Paris \& Charles University, Prague. p. 1-94.

Sakala, J. 2011. Silicified stem from the Late Eocene fossil locality of Kučlín (Czech Republic): overview and new remarks. Acta Musei Nationalis Pragae, Series B - Historia Naturalis, 67(3-4): 145-148

Sakala, J., Selmeczi, I. \& Hably, L., 2018. Reappraisal of Greguss' fossil wood types and figured specimens from the Cenozoic of Hungary: overview, corrected geology and systematical notes. - Fossil Imprint, 74(1-2): 101-114, Praha. ISSN 2533-4050 (print), ISSN 2533-4069 (on-line).

Sakinç, M., Aras, A., Yaltirak, C., Bati, Z. \& Çağatay, N., 2007. Trakya Karasal Tersiyerinde Silisleşmiş Ağaçlar, Paleoflora, Paleoklimatoloji, Paleocoğrafya [=Silicified trees in Tertiary of Thrace: Paleoflora, 
Paleoclimatology, Paleogeography]. Scientific and Technical Research Council of Turkey, Project Number: 103Y137. (in Turkish).

Shimakura, M., 1940. On the occurrence of Taxodioxylon albertense (Penhallow) in the Senonian of Karahuto (Japanese Saghalien). Journal of the Geological Society of Japan, 47 (556): 45-48. https://doi.org/10.5575/geosoc.47.45

Schmalhausen, J., 1890. Tertiäre Pflanzen der Insel Neusibirien. Mémoires de l'Académie Impériale des Sciences de St. Pétersbourg - Series 7, 37: 1-22.

Schoch, W., Heller, I., Schweingruber, F.H. \& Kienast, F., 2004. Wood anatomy of central European Species. Online version: www.woodanatomy.ch

Schönfeld, G., 1952. Mitteilungen über Funde aus dem Bornaer Braunkohlenrevier. Geologie, 1: 337-383.

Schönfeld, G., 1953. Mitteilungen über Funde aus dem Bornaer Braunkohlen Revier II. Geologie 2: 190-203.

Schönfeld, E., 1957. Ein pilzkranker Stamm von Cupressinoxylon cupressoides Kräusel, aus der hessischen Braunkohle. Senckenbergiana lethaea, 38: 109-119.

Schröter, C., 1880. Untersuchung über fossile Hölzer aus der arctischen Zone. In O. Heer: Flora fossilis arctica VI.1 and 2, Zürich (1880). Dissertation.

Schulz, C. \& Stützel, T., 2007. Evolution of taxodiaceous Cupressaceae (Coniferopsida). Organisms, Diversity \& Evolution, 7: 124-135.

Schweingrüber, F.H., 1990. Anatomie europäischer Hölzer (Anatomy of European woods). Verlag Paul Haupt, 1-765, Bern, Stuttgart.

Selling, O.H., 1944. On cupressoid root remains of Mesozoic age from the Arctic. Arkiv for Botanik 31A: 120.

Selmeier, A. \& Velitzelos, E., 2000. Neue Aufsammlungen von verkieselten Holzresten aus tertiären Sedimenten Griechenlands (Lesbos, Kastoria, Thrakien). Mitteilungen der Bayerischen Staatssammlung für Paläontologie und Historische Geologie, 40: 213-228.

Selmeier, A., 2001. Silicified Miocene woods from the North Bohemian Basin (Czech Republic) and from Kuzuluk, district Adapazari. Mitteilungen der Bayerischen Staatssammlung für Paläontologie und Historische Geologie, 41: 111-144.

Seward, A.C., 1919. Fossil Plants. V. 4. Cambridge Univ. Press, Cambridge. 656 pp.

Stewart, W.N. \& Rothwell, G.W., 1993. Paleobotany and the evolution of plants. Cambridge University Press, Cambridge, $521 \mathrm{p}$.

Stancu, J. \& Țicleanu, N., 1975. Date noi privind flora Badenianului din România. Dări de Seamă ale Şedinţelor (1973-1974). Institutul de Geologie și Geofizică - București, 61(3): 185-204. [in Romanian].

Stockmans, F. \& Willière, Y., 1934. Notes sur des bois fossiles récoltés en Belgique. Bulletin du Musée royal des sciences naturelles de Belgique, 10: 1-8.
Stopes, M.C., 1915. Catalogue of the Mesozoic Plants in the British Museum (Natural History). Part II: Lower Greensand (Aptian). Plants of Britain. XXXVI +360 pp. Trustees of British Museum, London.

Süss, H., 1989. Beitrag zur Holzanatomie der Pinaceae am Beispiel des Astholzes der Borstenkiefer, Pinus aristata Engelm. Feddes Repertorium, 100: 617-624.

Süss, H., 1997. Tetraclinoxylon velitzelosi sp. nova. ein neues fossiles Holz aus tertiären Schichten des Versteinerten Waldes von Lesbos. Feddes Repertorium, 108: 289-298.

Süss, H., 2003. Zwei neue fossile Hölzer der Morphogattung Ginkgoxylon Saporta emend. Süss aus tertiären Schichten der Insel Lesbos, Griechenland, mit einer Übersicht über Fossilien mit ginkgoaler Holzstruktur. Feddes Repertorium, 114(5-6): 301-319.

Süss, H. \& Rathner, U. 1998. Ein neues fossiles Holz, Juniperoxylon wagneri sp. nova, aus der miozänen Braunkohle von Wetro (Oberlausitz/Sachsen, Deutschland). Feddes Repertorium, 109: 15-24.

Süss, H. \& Velitzelos, E., 1993. Eine neue ProtoPinaceae der Formgattung Pinoxylon Knowlton emmend. Read, P. parenchymatosum sp. nov., aus tertiaren Schichten der Insel Limnos, Griechenland. Feddes Repertorium, 104: 335-341.

Süss, H. \& Velitzelos, E., 1994a. Ein neues fossils Koniferenholz, Taxaceoxylon biseriatum sp. nov., aus tertiären Schichten der Insel Lesbos, Griechenland. Feddes Repertorium, 105: 257-269.

Süss, H. \& Velitzelos, E., 1994b. Zwei neue tertiäre Hölzer der Gattung Pinoxylon Knowlton emend. Read aus dem Versteinerten Wald von Lesbos, Griechenland. Feddes Repertorium, 105: 403-423.

Süss, H. \& Velitzelos, E., 1997. Fossile Hölzer der Familie Taxodiaceae aus tertiären Schichten des Versteinerten Waldes von Lesbos, Griechenland. Feddes Repertorium, 108: 1-30, 5 Abb., 7 Taf.

Süss, H. \& Velitzelos, E., 1998. Thujoxylon antissum sp. nov. ein fossiles Wurzelholz aus tertiären Schichten des Versteinerten Waldes von Lesbos, Griechenland. Feddes Repertorium, 109(5-6): 341-350.

Süss, H. \& Velitzelos, E., 1999. Chimairoidoxylon lesboense gen. nov. sp. nova, ein endemisches Holzfossil aus dem Tertiär von Lesbos, Griechenland, Feddes Repertorium, 110: 329-339.

Süss, H. \& Velitzelos, E., 2000. Zwei neue fossile Hölzer der Formgattung Podocarpoxylon Gothan aus tertiären Schichten der Insel Lesbos, Griechenland. Feddes Repertorium, 111(3-4): 135-149.

Süss, H. \& Velitzelos, E., 2001. Chimairoidoxylon conspicuum sp. nov., ein neues fossiles Holz der Formgattung Chimairoidoxylon Süss \& Velitzelos emend. Sass, mit einer Übersicht über das Vorkommen fossiler Hölzer auf der Insel Lesbos, Griechenland. Feddes Repert., 112(3-4): 149-157. 
Süss, H. \& Velitzelos, E., 2008. Lebensspuren holzzerstörender Organismen an fossilen Hölzern aus dem Tertiär der Insel Lesbos, Griechenland. Fossil Record, 4(1): 57-69.

Süss, H. \& Velitzelos, E., 2009. Zwei neue fossile Hölzer der Morphogattung Pinoxylon Knowlton emend. Read aus dem Tertiär der Insel Lesbos, Griechenland. Feddes Repert., 120: 3-14.

Süss, H. \& Velitzelos, E., 2010. Lesbosoxylon gen. nov., eine neue Morphogattung mit dem Typus Lesbosoxylon ventricosuradiatum sp.nov. aus dem Tertiar der Insel Lesbos, Griechenland. Feddes Repert., 121(12): 18-26.

Sweet, R., 1826. Sweet's Hortus Britannicus: or a catalogue of plants cultivated in the gardens of Great Britain, arranged in natural orders, p. 372, London.

Teodoridis, V. \& Sakala, J., 2008. Early Miocene conifer macrofossils from the Most Basin (Czech Republic). Neues Jahrbuch für Geologie und Paläontologie Abhandlungen, 250: 287-312, Stuttgart.

Tian, N., Zhu, ZH., Wang, Y., Philippe, M., Chou, C. \& Xie, A., 2018. Sequoioxylon zhangii sp. nov. (Sequoioideae, Cupressaceae s.1.), a new coniferous wood from the Upper Cretaceous in Heilongjiang Province, Northeast China. Review of Palaeobotany and Palynology, 257: 85-94. https://doi.org/10.1016/j.revpalbo.2018.07.008.

Tiemei, Y., Chengsen, L. \& Syabryaj, S., 2013. Pliocene taxodiaceous fossil wood from southwestern Ukraine and its palaeoenvironmental implications. Journal of Palaeogeography, 2(4): 362-368.

Torrey, R.E., 1923. The comparative anatomy and phylogeny of the Coniferales, Part. 3: Mesozoic and Tertiary coniferous woods. Memoirs read before the Boston Society of Natural History, 6: 39-106.

Turland, N.J., Wiersema, J.H., Barrie, F.R., Greuter, W., Hawksworth, D.L., Herendeen, P.S., Knapp, S., Kusber, W.-H., Li, D.-Z., Marhold, K., May, T.W., McNeill, J., Monro, A.M., Prado, J., Price, M.J. \& Smith, G.F. (eds.), 2018. International Code of Nomenclature for algae, fungi, and plants (Shenzhen Code) adopted by the Nineteenth International Botanical Congress Shenzhen, China, July 2017. Regnum Vegetabile, 159. Glashütten: Koeltz Botanical Books. DOI: $10.12705 /$ Code. 2018

Uhl, D., Dolezych, M. \& Böhme, M., 2014. Taxodioxylon-like charcoal from the Late Miocene of western Bulgaria. Acta Palaeobotanica 54(1): 101-111, DOI: 10.2478/acpa-2014-0004

Unger, F., 1847. Chloris protogaea. Beiträge zur Flora der Vorwelt, Leipzig, 8-10: 93-149

Vallin, S., 1966. Sur une Cupressaceae fossile du Portugal. Boletim de Sociedade Geológica de Portugal, Lisboa, XVI(I-II):125-136, 2 pl.

Van der Burgh, J., 1964. Hölzer der niederrheinischen Braunkohlenformation,1. Hölzer der Braunkohlen- grube "Anna" zu Haanrade (Niederländisch Limburg). Acta Botanica Neerlandica, 13(2): 250-301.

Van der Burgh, J. 1973. Hölzer der niederrheinischen Braunkohlenformation. 2. Hölzer der Braunkohlengruben "Maria Theresia" zu Herzogenrath, "Zukunft West" zu Eschweiler und "Victor" (Zülpich-Mitte) zu Zülpich. Nebst einer systematisch-anatomischen Bearbeitung der Gattung Pinus L. Review of Palaeobotany and Palynology 15(2): 73-275.

Van der Burgh, J. \& Meijer, J.J.F., 1996. Taxodioxylon gypsaceum and its botanical affinities. Curent Science, 70(5): 373-378.

Vasileiadou, K. \& Zouros, N., 2012. Early Miocene micromammals from the Lesvos Petrified Forest (Greece): preliminary results. Palaeobiodiversity and Palaeoenvironments, 92: 249-264.

Vassio, E., Martinetto, E., Dolezych, M. \& van der Burgh, J., 2008. Wood anatomy of the Glyptostrobus europaeus "whole-plant" from a Pliocene fossil forest of Italy. Review of Palaeobotany and Palynology 151: 81-89 journal homepage: www.elsevier.com/locate/revpalbo

Vaudois, N. \& Privé, C., 1971. Révision des bois fossiles de Cupressaceae. Palaeontographica, Abt. B, Paläophytol., 134: 61-86.

Velitzelos, D., Bouchal, J.M. \& Denk, T., 2014. Review of the Cenozoic floras and vegetation of Greece. Review of Palaeobotany and Palynology, 204: 56-117.

Velitzelos, D., Iamandei, S., Iamandei, E. \& Velitzelos, E., 2019. Palaeoxylotomical studies in the Cenozoic petrified forests of Greece. Part one - palms. Acta Palaeobotanica 59(2): 289-350. DOI: 10.2478/acpa2019-0012; e-ISSN 2082-0259; ISSN 0001-6594.

Velitzelos, E., Kvaček, Z \& Velitzelos, D., 2002. New Oligocene leaf floras from the volcanic complex of the Evros Mountains (Abstracts). $6^{\text {th }}$ European Paleobotany-Palynology Conference Athens, Greece, 2002, Abstracts volume: 185-186

Visscher, G.E. \& Jagels, R., 2003. Separation of Metasequoia and Glyptostrobus (Cupressaceae) based on wood anatomy. IAWA Journal, 24: 439-450.

Vogellehner, D., 1967. Zur Anatomie und Phylogenie de Mesozoischer Gymnospermenholzer, 7: Prodromus zu einer Monographie de Protopinaceae. I. Die Protopinoiden Holzer des Trias. Palaeontographica Abt. B, 121(1-3): 30-51.

Vogellehner, D., 1968. Zur Anatomie und Phylogenie de Mesozoischer Gymnospermenholzer, 7: Prodromus zu einer Monographie de Protopinaceae. II. Die Protopinoiden Holzer des Jura. Palaeontographica Abt. B, 124(4 -6): 125-162.

Voudouris, P., Velitzelos, D., Velitzelos, E. \& Thewald, U., 2007. Petrified wood occurrences in western Thrace and Limnos Island: mineralogy, geochemistry and depositional environment. Bulletin of the Geological Society of Greece, 40: 238-250. 
Watari, S. \& Nishida, M., 1973. A Juniperoxylon from the Tertiary of Hokkaido. Journal of Japanese Botany, 48: $154-159$.

Watson, L. \& Dallwitz, M.J., 2008 onwards. The families of gymnosperms. Version: 5th August 2019. deltaintkey.com Wheeler, E.A. 2011. InsideWood - a web resource for hardwood anatomy. IAWA Journal 32 (2): 199-211.

Wheeler, E.A. \& Lehman, T.M., 2005. CretaceousPaleocene conifer woods from Big Bend National Park, Texas. Palaeogeography, Palaeoclimatology, Palaeoecology 226: 233-258.
Xiang, Q., \& Li, J., 2005. Derivation of Xanthocyparis and Juniperus from within Cupressus: Evidence from Sequences of nrDNA Internal Transcribed Spacer Region. Harvard Papers in Botany, 9(2): 375-382

Zalewska, Z., 1953. Treciorzedowe szczatki drewna z Turowa nad Nysa Luzycka. Część I. (=Wood remains from Turów nad Nysa Luzycka. Part I.). Acta Geologica Polonica, III(4): 481-543. [in Polish]

Zouros, N., Velitzelos, E., Valiakos, I. \& Labaki, O., 2007. The Plaka Petrified Forest Park in Western Lesvos - Greece. Proceedings of the $11^{\text {th }}$ International Congress. Bulletin of the Geological Society of Greece, 40: 1880-1891. 